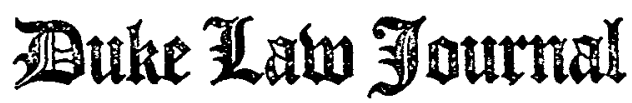

\begin{tabular}{lll}
\hline VOLUME 1974 & JANUARY & NUMBER 6 \\
\hline
\end{tabular}

\section{REMOVAL OF THE PRESIDENT: RESIGNATION AND THE PROCEDURAL LAW OF IMPEACHMIENT}

\author{
EDWIN BROWN FIRMAGE* \\ R. COLlin MANGrum**
}

I. INTRODUCTION

II. The English Precedents

III. HOUSE IMPEACHMENT PROCEDURE
A. The Initiation of Preliminary Investigations in the House
B. The Irrelevance of Probable Cause to Impeach Named Individuals
C. Investigations Preparatory to the Articles of Impeachment
D. The Drafting of Articles of Inpeachment
E. The Right of the Accused to Appear in the Course of the House Investigation
F. The Burden of Proof for the Adoption of the Articles
G. The Public Eye on the Adoption of the Articles of Impeachment
H. The Committee Report on the Articles of Impeachment
I. The Vote on the Articles on the Floor of the House

* Professor of Law, University of Utah College of Law; J.D. 1963, LL.M. I964, J.S.D. 1964, University of Chicago; Fellow in Law and the Humanities, 1974-75 Harvard University.

** Research Assistant, University of Utah College of Law, J.D., 1975.

THE FOLLOWING CITATIONS WILL BE USED IN THIS ARTICLE:

R. Berger, Executive Privilege: A Constitumional MYth (1974) thereinafter cited as EXecutive PrivILEge];

R. Berger, Impeachment: The Constitutional Problems (1973) [hereinafter cited as R. BERGER];

C. Cannon, Cannon's Congressional Precedents (1935) theremafter cited as CANNON's];

L. Deschler, Constitution, Manual, and Rules of the House of RepresentaTIVES, 93D CONGRESS (1973), containing Jefferson's Manual [hereinafter cited as Manual!;

J. Elliott, The Debates IN The Several State Conventions (1937) [hereinafter cited as J. ELLIOTT];

A. C. Hinds, Hinds' Precedents of the House of Representattves (1907) [hereinafter cited as HiNDs'];

J. KENT, COMMENTARIES ON AMERICAN LAW (2d ed. 1832) [hereinafter cited as J. KENT];

The Records of THE Federal Convention of 1787 (M. Farrand ed. 1911) [hereinafter cited as REcoRDs];

J. Story, Commentaries on THE Constitution of the United States (5th ed. 1905) [hereinafter cited as J. STORY]. 
J. The Effects of Recesses and Adjournments on the Impeachment Process

$\dot{K}$. The House Selection of Managers

IV. Senate Impenchment Procedure

A. Does the Senate Sit as a Court?

B. Initiation of the Senate Trial

C. The Presiding Officer

D. Conduct of the Inupeachment Trial

E. Evidentiary Rulings

F. Final Arguments and Voting

G. Judgment

V. RAISING THE DEFense of Executtve PRIVILEge

A. Executive Privilege Based on Separation of Powers

B. Withholding Information When the Public Interest Requires Executive Secrecy

C. Withholding Information on the Basis of a Statutory Privilege

VI. EXCLUDING EVIDENCE ON OTHER CONSTTTUTIONAL OR EVIDENTIARY GROUNDS

VII. IMPEACHMENT AND JUDICIAL REVIEW

VIII. IMPEACHMENT AND INDICTMENT

IX. RESIGNATION AND IMPEACHMENT

$X$. PARDON AND IMPEACHMENT

A. Historical Analysis of Pardon

B. Elements of Pardon

XI. ConCLUSION

C. The Nixon Pardon and Beyond

XII. EPIIOGUE

XiII. APPENDICES

Actuated by these sentiments our ancestors arrayed themselves against the government in one huge and compact mass. All ranks, all parties, all Protestant sects, made up that vast Phalanx. In the van were the Lords Spiritual and Temporal, Then came the landed gentry and the clergy; both the Universities, all the Inns of Court, merchants, shopkeepers, farmers, the porters who plied in the strects of the great towns, the peasants who ploughed the fields. The league against the King included the very foremast men who manned his ships, the very sentinels who guarded his palace. The names of Whig and Tory were for a moment forgotten. The old Exclusionist took the old Abhorrer by the hand. Episcopalians, Presbyterians, Independents, Baptists, forgot their long feuds, and remembered only their common Protestantism and their common danger . . . . The coalition of 1688 was produced, and could be produced, only by tyranny which approached to insanity, and by danger which threatened at once all the great institutions of the country.

Macaulay on the Fall of James $\Pi^{1}$

\section{INTRODUCTION}

The aborted proceeding to impeach Richard Nixon has stimulated debate about the appropriateness of the impeachment process as a check upon the arbitrary use of presidential power. Impeachment has been criticized as a cumbersome, agonizingly slow, and unjustifiably expensive way for Congress to express its will, extracting a cost in an abraded electorate suffering further with duties of government unmet

1. 1 T. Macaulay, The History of England from the ACcession of James II 803-04 (1906). 
while Congress and the presidency are consumed with their offensive and defensive roles in the process. Termination of the impeachment proceeding without an admission of moral guilt (only "errors of judgment") or a finding of legal responsibility is a disquieting denouement for the Watergate tragedy. Further, such proceedings could not adequately resolve whether a President who resigns when faced with certain removal should be allowed extensive federal retirement benefits or if a resigning President should have immunity from prosecution for criminal acts committed while in office-now a mooted question as to federal prosecution because of President Ford's pardon.

Congressman Henry Reuss has proposed in response to this crisis the adoption of a modified form of responsible government to be accomplished by a constitutional amendment which would permit the removal of the President by a three-fifths vote of no confidence by the members of each House of Congress. ${ }^{2}$ A new President and VicePresident wonld be chosen in a special election held following such a vote. Under such a system, a President could be removed simply upon the basis of a strongly felt difference on policy or for an error in judgment, rather than upon conviction of the commission of treason, bribery, or other high crimes and misdemeanors. The President would enjoy office at the sufferance of Congress.

It is suggested, however, that when considered within the parameters of our present system of government, the process of impeachment, even if it culminates in presidential resignation, has served as an effective deterrent to the arbitrary abuse of presidential power. A radical change in the law of presidential removal is not called for by the Nixon resignation.

Of course, impeachment is cumbersome, heavy artillery in the arsenal of democratic government, not designed to go after a mousea rat on occasion perhaps, but never a mouse. Other procedures are available for lesser gaine, mcluding a vote of censure.

Nor is it meant to be quick. Within a governmental system of checks and balances in which the President possesses an electoral mandate equal to and independent of Congress, it wonld violate an expression of the people's will to accomplish his removal from office before not only Congress but also the people recognize by a substantial majority that legitimacy had departed, the mandate finished. ${ }^{3}$ of

2. H. JoINT Res. No. 903, 93d Cong., 2d Sess. 1111 (1974). See also Havighurst, Doing Away with Presidential Impeachment: The Advantages of Parliamentary Government, 1974 ARIz. L. REV. 223.

3. The term "legitimacy" is not used here in the legalistic sense of the acquisition of power by formally orthodox or proper means. Rather, it is 
course, the efficiency of that process depends upon the speed with which evidence can be produced. Thus, where immediate presidential compliance with congressional fact-finding incident to an impeachment inquiry would appropriately shorten the process, categorical refusal to coinply with congressional subpoenas should be considered an impeachable offense, since toleration of such failure would destroy the impeachment provision.

In the sense that the process was designed ultimately to protect the country against corruption and the abuse of power by reinoving rather than pumishing the offender, impeachment works; this is appreciated particularly when it is understood that resignation is not "extralegal," 4 apart froin the process, but rather is an historically often-used and a constitutionally mandated ${ }^{5}$ part of the system. The framers deinanded the preservation of separate criminal proceedings, to accomplish pumishment, as the price paid for the renoval of English criminal sanctions froin the process of impeachment. ${ }^{6}$

Finally, rejection of the parliamentary mode does not necessarily suggest a qualitative judgment in favor of a governmental system of separated branches balanced and checked. It is simply a recognition that after 200 years of such governance, the separation of coordinate branches is woven into the warp and woof of the community, and is not able to be extracted and replaced without rending the whole.

Our purposes, therefore, are twofold: first, to analyze in detail the American procedure of impeachinent, in the hope that wider knowledge of its provisions will render the use of the process more effective in constraining executive and judicial power; and second, to offer suggestions for improving the process within the bounds of our historical constitutional system. In that which follows, the first three sections present an analysis of the procedural law of the impeachment process

used, as the political scientist or sociologist would use it, to connote a sufficient affinity between the people and the institutions of government, based upon the preexistence of a cultural harmony between them, that allegiance naturally results without coercion. Firmage, Law and the Indochina War: A Retrospective View, 1974 UTAH L. REV. 1, 21, reprinted in 4 The Vietnam War and International Law (R. Falk ed. 1974).

See also Firmage, The War of National Liberation and the Third World, in LAW AND CIVIL WAR IN THE MODERN WorLd (J. Moore ed. 1974). Lipset has defined legitimacy as the capacity of a political system to advance and maintain the belief that existing political institutions are the most appropriate for the community. Lipset, Some Social Requisites of Democracy: Economic Development and Political Legitimacy, 53 AM. PoL. SCI. REV. 69, 86 (1959).

4. Cf. Kurland, Watergate, Impeachment and the Constitution, 45 Mrss. L.J. 531, 579 (1974).

5. U.S. Const. art. II, $\& 1$, cl. 8 .

6. See notes $40,332-34$ infra and accompanying text. 
as it operates when no objections or defenses extraneous to the impeachment process itself are raised by the defendant to impede its normal resolution. Later sections discuss the various immunities, privileges, rights, and powers which a party defendant to an impeachment proceeding may exercise in an effort to thwart, delay, or reverse the course of the congressional impeachment process. The final sections treat the effect of resignation upon an attempted impeachment and the effect upon the impeachment process of the pardon granted Mr. Nixon by President Ford.

Underlying the impeachment powers are four fundamental precepts which should guide any discussion of the process of presidential impeachment particularly, and each recommendation for its improvement and refinement. First, the impeachment power was written into the Constitution to protect the principle of separation of powers. Impeachment had developed in England as a parliamentary process designed to protect and ultimately to enhance the power of Parliament against constitutional abuses and excesses of Tudor and Stuart ministers bent upon asserting absolutist power for the Crown against the prerogatives of Parliainent. By this means, the King's ministers were brought under the rule of law, and executive responsibility to Parliament was established. ${ }^{7}$ Similarly, impeachment procedure was placed in the United States Constitution by founding fathers steeped in English law and history, ${ }^{8}$ primarily as a check upon overweening executive power, as an "exception to [the] principle" of separation of powers in order that that very principle might be preserved with governmental branches checked and balanced.

Second, as a prophylactic against the usurpation of powers, ${ }^{30}$

7. See W. Holdsworth, A History of ENGlish LaW 382 (3d ed. 1922); C. RobERTs, The Growth of Responsible Government in Stuart England passim (1966). It should be noted that the powerful Tudor monarchy was not simply aimed at containing or diminishing the power of its potential rival, parliament. Equally fundamental in explaining the Tudor quest for absolute power was its natural reaction against Lancastrian misrule and the consequent baronial anarchy: the collapse of trial by jury, the subversion of local government by large landowners, the control of parliamentary elections by local barons, and the crumbling legal system at Westminster and in the country. See T. Plucknett, A Concise History of the COMmon LAW 35-38 (5th ed. 1956).

8. Many of the members of the Convention had studied in England, including nine lawyers who had practiced there. R. BERGER 87 n.160. Also, the English impeachment trial of Warren Hastings was in progress during the Constitutional Convention and was referred to in the debates. 2 RECORDS 550. dinot).

9. 1 ANNALs of CoNG. 527 (1789) [1789-1824] (remarks of Representative Bou-

10. Roberts noted that impeachment during the seventeenth century was not aimed at preventing or punishing private wrongs, nor was it stimulated by party policy differ- 
impeachment was intended primarily to protect the integrity of government against political offenses. It cannot seriously be questioned that impeachment will lie for "great offenses" which arise out of misuse of constitutional powers which nevertheless does not constitute a criminally indictable offense. James Wilson, perhaps the greatest legal mind in the Convention, concluded that

[i]mpeachments . . . come not . . . within the sphere of ordinary jurisprudence. They are founded on different primciples; are governed by different maxims, and are directed to different objects: for this reason, the trial and punishment of an offense on an impeachment, is no bar to a trial and punishment of the same offense at common law. ${ }^{11}$

Impeachment, Wilson wrote, was "confined to political characters, to political crimes and misdemeanors, and to political punishments."12 Similarly Chancellor Kent taught that "[i]f . . . the President will use the authority of his station to violate the Constitution or law of the land, the House of Representatives will arrest him in his career by resorting to the power of impeachment."13 Thus, the Congress is called upon to curtail any abuse of political office through the exercise of its own political powers as representatives of the people. ${ }^{14}$

ences, it was "not the venting of private spleen or party hatreds" but rather a prophylactic against usurpation of power. C. RoBERTs, supra note 7, at 32 .

11. 1 J. WILSON, Works 452 (1804).

12. $2 \mathrm{id}$. at 166.

13. 1 J. KENT 289.

14. Firmage, The Law of Presidential Impeachment, 1973 UTAH L. Rev. 681. George Mason in the Constitutional Convention debated the necessity of having a check on the Executive to ensure executive responsibility to the constitutional structure of this country.

[S]ome provision should be made for defending the Commumity [against] the incapacity, negligence or perfidy of the Chief Magistrate. The limitation of the period of his service... Was not a sufficient security. He might lose his capacity after his appointment. He might pervert his admiration imto a scheme of peculation or oppression. ... In the case of the Executive Magistracy which was to be administered by a single man, loss of capacity or corruption was more within the compass of probable events, and either of them might be fatal to the Republic. 1 Reconds 65-66.

Mason further noted that "attempts to subvert the Constitution" should constitute an impeachable offense. Id. at 550. Benjamin Franklin noted that impeachment of the Chief Executive was essential to avoid political assassination when the Executive had "rendered himself obnoxious." Id. at 65. Edmund Randolph also commented on the necessity of inpeachment to provide against Executive abuse of power:

The Executive will have great opportunities of abusing. power; particularly in time of war when the military force, and in some respects the public money will be in his hands. Should no regular punishment be provided, it will be irregularly inflicted by tumults and insurrections. Id. at 67.

Messrs. Jones, Bowdoin, and Stillman also asserted in the Massachusetts convention that presidential impeachment would lie for "abuse of power," 2 J. ELLIOT 75, 81-86, 168-69, as did Francis Corbin in the Virginia convention, $3 \mathrm{id}$. at 509-11, and Iredell in the North Carolina convention, 4 id, at 127. 
Third, the impeachment power was designed to preserve the basic structure of our society. While the impeachment process is fundamentally political, ${ }^{15}$ it was designed to protect the foundation of the state itself-not to create a sanction for misjudgment or to settle disputes over policy, both appropriately dealt with through the electoral process. (To hold otherwise would do violence to that principle which undergirds the Constitution - the separation of powers-which the impeachment power was designed to preserve.) It was this that Hamilton referred to when he stated that impeachable offenses have "a nature which may with peculiar propriety be denominated POLITICAL, as they relate chiefly to injuries done immediately, to the society itself." Mason regarded the purpose of impeachment to be the prevention of "great and dangerous offenses," resulting from "attempts to subvert the Constitution."17 Iredell, later to become a Justice of the Supreme Court, in the North Carolina ratifying convention, stated that impeachment would arise from "acts of great injury to the community."18 Madison saw impeachment as a preventive against a president perverting "his administration into a scheme of peculation or oppression"; ${ }^{19}$ Morris perceived it as a deterrent for bribery. ${ }^{20}$ In part it was this conception of the impeachment proceeding as a political institution which made it logical to transfer the forum of the impeachment trial from the Supreme Court as provided by an early draft of the Constitution, to the Senate. ${ }^{21}$

Finally, being a political process, impeachment should not be viewed as a duplication of the criminal process. ${ }^{22}$ The impeachment process was designed to be neither a criminal proceeding, nor, in a strictly techmical sense, a juridical trial. Removal from office cannot be viewed as criminal punishment or its equivalent. To hold otherwise would be to assume that an office liolder was possessed of an indefeasible property interest in the office. Joseph Story spoke of impeacl1inent as "a proceeding purely of a political nature. It is not so much designed to punish an offender as to secure the state against gross official misdemeanors. It touches neither his person nor his property, but simply divests him of his political capacity." ${ }^{\text {"23 }}$ This conclusion was

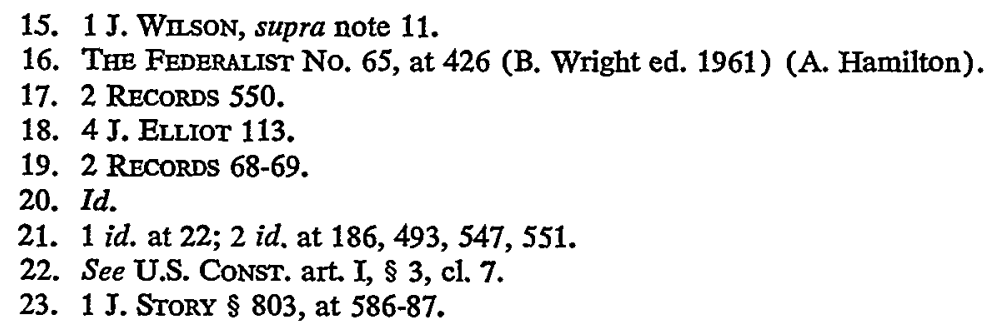


consistently held by virtually every early commentator on the process of impeachment. ${ }^{24}$ Nevertheless, while the process was shorn of criminal sanctions, ${ }^{25}$ certain aspects of criminal procedure and its linguistic trappings were retained from its English origins as a criminal proceeding within Parliament. ${ }^{28}$

To a large extent, it was this retention of criminal judicial forms and practices which has given rise to further questions about what rights and immunities a defendant is enititled to raise before an impeachment court. Does the scope of executive privilege afford any protection whatever in a trial by the Senate? May fourth and fifth amendment rights be raised to exclude certain evidence, and who may assert such of the argunients which are likely to be relevant based, upon the rights? Which, if any, of the imterloctory or final rulings and judgments of the Senate nuay be subjected to judicial review? While many of these questions must wait upon the political moment in which they will arise before they can be answered authoritatively, we shall present fundamental precepts and precedents underpinning the procedural law of impeachment.

\section{The English Precedents}

It has been said that '[t]he 'crowning achievenient' of the fourteenth century . . . was to devise impeachments as a procedure for trial of the King's ministers, who were otherwise not reachable."27 Unlike the bill of attainder where persons were sentenced to death without any trial and conviction in the ordinary course of judicial proceedings, impeachment involved both an indictment by the House of Cominons as a grand jury of the nation and a trial at the bar of the House of

24. E.g., Edward Rutledge and General C.C. Pinckney considered impeachment proper were a President to betray or abuse his public trust. 4 J. Elifotr 276, 281. Mason and Morris recognized gross personal corruption as grounds for impeachment. 2 RECORDS 68-69.

25. Judgment in Cases of Impeachment shall not extend further than to removal from Office, and disqualification to hold and enjoy any Office of honor, Trust, or Profit under the United States: but the Party convicted shall nevertheless be liable and subject to Indictment, Trial, Judgment, and Punishment, according to Law. U.S. CoNST. art. I, \& 3, cl. 7.

26. Article two, section four provides for removal from office on "conviction of Treason, Bribery, or other high Crimes and Misdemeanors." Article one, section three, clause six gives the Senate "sole Power to try all Impeachments" and later speaks of no person being "convicted" without the concurrence of two-thirds of the members present; article two, section two, clause one gives the President the "Power to grant Reprieves and Pardons for Offenses against the United States" but excepts impeachment; and article three, section two, clause three states that "[t]he Trial of all Crimes, except in Cases of Impeachment, shall be by Jury."

27. R. BERGRR 26. 
Lords. Through the growth of parliamentary impeachment there emerged a procedural common law of impeachment which was familiar to the framers of the American Constitution and which has substantially influenced the proceedings in American impeachment cases to the present.

It was the Enghish law of impeachment, as summarized in Thomas Jefferson's Manual of Parliamentary Practice, ${ }^{28}$ that was referred to and followed, with some modifications, in the American impeachment cases. Under English law, the House of Commons, as the "grand inquest of the nation," 29 generally conducted ex parte investigations against the accused, ${ }^{30}$ passed resolutions containing a cliarge of impeacliable conduct on the part of the accused, ${ }^{31}$ directed some nember to impeach the accused by oral accusation at the bar of the House of Lords, ${ }^{32}$ and thereafter appointed inanagers to present articles of impeachment and to act as suitors for penal justice agamst the impeached at the bar of the Lords. ${ }^{33}$ The House of Lords then issued process against the impeached party ${ }^{34}$ and committed him where necessary. ${ }^{35}$ Subsequently, the Lords acted as judges in the trial before their bar. ${ }^{36}$ The trial before the House of Lords essentially followed the criminal procedure found in the courts and applied the same rules of evidence ${ }^{37}$ with the judgment itself controlled by legal

28. Jefferson's Manual was prepared by Thomas Jefferson for his own guidance as President of the Senate in the years of his Vice-Presidency, from 1797 to 1801. In 1837 the House, by a rule which still exists, provided that the provisions of the Manual should "govern the House in all cases to which they are applicable and in which they are not inconsistent with the standing rules and orders of the House." Manual 121 n.a.

29. Manual $\S 602$, at 295. See also 3 HINDs' $\S$ 2004, 2026.

30. In the 1852 impeachment proceeding of District Judge Watrous, the issue as to the propriety of ex parte investigations was debated and English citations were given in support. See 3 Hinds' $\$ 2496$, at 996-97. See also 3 id. \$ 2326 (In the Peck impeachment case the nature of the inquiry preliminary to impeachment was discussed in regard to its conformity with English precedents.).

31. Manual $\$ 602$, at 295 . See, e.g., 3 Hinds' $\$ 2038$ (discussing the Blount impeachment in which the House, following the precedent of the Hastings trial, passed an impeachment resolution without accompanying articles and presented it to the Senate).

32. Manual $\$ 602$, at 295 . In the Hastings trial, for example, Mr. Burke "went up to the House of Lords and impeached him in words . . . " 3 Hinds' 2295 , at 647.

33. 3 Hinds' $\$ 2004,2026$; Manual $\S 602$, at 295. For a discussion of the role of the managers under English precedent, see 3 Hinds' $\$ \$ 2136-39$.

34. Manual $\S 608$, at 297 . "Under the parliamentary law, if the party impeached at the bar of the Lords does not appear, proclamations are issued giving him a day to appear." 3 Hinds' $\$ 2116$, at 438.

35. Manual $\S 602$, at 296 . The House in the Blount impeachment followed English precedent and required the sequestration of the respondent from his seat in the Senate. 3 HINDS' 22295 , at 646 .

36. 3 Hinds' $\$ 2056$, at 378; Manual $\S$ 615-18, at 301-03.

37. Manual $\$ 619$, at 304. See also 3 Hinds' $\$ 2155$, at 485 . In the Johnson trial 
precedents. ${ }^{38}$ An impeachment proceeding was not discontinued by the dissolution of Parliament but was resumed by the subsequent Parhament. ${ }^{30}$

Although English precedent lias been relied on heavily in the American impeachment cases, Congress has the constitutional authority to control its procedure without regard to earlier precedent. Moreover, a persuasive argument can be unade for substantially inodifying the English procedure to accommodate special circumstances present in American impeachment cases, since one of the marked distinctions between Enghish and American impeachments is that the English proceeding included the imposition of criminal sanctions, while criminal penalties are excluded from American proceedings. ${ }^{40}$ Consequently, a relaxation of the strict rules of evidence and procedure used in a criminal proceeding is appropriate in American impeachment, which is more closely analogous to a civil trial. While Congress has rejected efforts toward general reforn of its impeachment procedure ${ }^{41}$-professing to retain the Enghish model with its criminal law superstructure -it has often modified its procedural rules in individual instances.

\section{House Impeachment Procedure}

The Commons, as the grand inquest of the nation, becomes suitors for penal justice. . . . The general course is to pass a resolution containing a crimmal charge against the supposed delinquent, and then to direct some member to impeach him by oral accusation, at the bar of the House of Lords, in the name of the Commons. ${ }^{42}$

Sole power of impeachment is conferred upon the House of Representatives by the Constitution. ${ }^{43}$ The manner in which impeach-

the necessity of strictly following the rules of evidence was discussed and the practice was continued on the strength of English precedent. 3 id. $\S 2238$, at 565 .

38. Manual $\S 619$, at 304 . Although it has been urged that impeachment under the English law was merely an extension of the criminal law and thus would be appropriate only for indictable crimes, this view has been substantially repudiated. See R. BERGER 59-67. Accordingly, the stateinent that judgments on impeachment were controlled by legal precedent refers to the fact that while "English impeachments did not require an indictable crime they were nonetheless criminal proceedings because conviction was punishable by death, imprisonment, or heavy fine." Id. at 67 .

39. 3 Hinds' $\$ 2005$, at 308; Manual $\$ 620$, at 305 .

40. See, e.g., 3 HinDs' $\$ 2510$, at 1016 (discussion of the Colfax impeachment in which the Judiciary Cominittee concluded that the power of impeachment under the Constitution was remedial rather than punitive).

41. Such reforms have been unsuccessfully attempted in the several impeachments. See notes 163 \& 226 infra.

42. Manual $\S 602$, at 295 (citation omitted).

43. U.S. Const. art. I, $\& 2$ (providing that "[T]he House of Representatives . . . shall have the sole power of impeachment"). 
ments are conducted in the House, however, is not described in the Constitution but instead follows the accretion of procedural precedents which are modified from time to time by House resolutions. There follows an examination of these precedents as they are found in the thirteen impeachments voted by the House, ${ }^{44}$ with special reference to the Nixon proceeding whenever deviation from precedent occurred.

The House has generally followed its Enghish and American precedents, even though the Constitution clearly authorizes it to abandon these precedents and to develop new procedures. Nontheless, where equitable or public policy considerations have been urged in support of a particular change from procedural precedent, the House has been amenable to innovative modifications. These changes have led to the eventual adoption of specific procedures to guide the impeachment process through the House from its earliest imitiatory investigations to presentment before the Senate.

An impeachment resolution is first presented to the House, and if that body sees fit, the matter is referred to the House Judiciary Committee for investigation. This Committee serves two purposes: it recommends to the House whether to vote to impeach, and it drafts articles of impeachment to be issued against the accused in the trial by the Senate. Following the Committee's report on the articles of impeachment, the full House votes, and if it impeaches, managers are selected to present the case at the bar of the Senate. At certain stages in this process, questions arise about the necessity of showing probable cause, the burden of proof, the right of the accused to be represented, and the degree of specificity and publicity which should accompany the House's decisions and formulations of its case agamst an accused public officer.

\section{A. The Initiation of Preliminary Investigations in the House}

Impeachment imquiries in the House are imitiated by Congress in response to accusations made against civil officers. ${ }^{45}$ Congressmen have preferred charges in various ways. ${ }^{46}$ Individual House members

44. Senator Blount (1797-99); District Judge Pickering (1803-04); Supreme Court Justice Chase (1804-05); District Judge Peck (1830-31); District Judge Humphreys (1862); President Johnson (1867-68); District Judge Delahay (1873); Secretary of War Belknap (1876); District Judge Swayne (1903-05); Circuit Judge Archbald (1912-13); District Judge English (1925-26); District Judge Louderback (1932-33); District Judge Setter (1933-36).

45. The term "civil officers" includes both officers of the executive branch of government and federal judges. The impeachment precedents that do exist primarily involve the impeachment of federal judges. See note 44 supra.

46. The process of preferring charges has no prescribed formality or technical re- 
have initiated impeachment investigations by preferring charges entirely on their own responsibility, usually reinforced by accusations nrade by others. Investigations have also been stimulated by presidential inessages, accusations contained in meinorials, ${ }^{47}$ and as a result of general congressional investigations. Where individual House ineinbers present impeachment resolutions and propose House investigation of alleged misconduct on the part of civil officers, these are presented before the House as a question of highest privilege. ${ }^{48}$ As a question of privilege, an impeachment resolution may be presented at any time, irrespective of previous action by the House. ${ }^{49}$ The following examination of inipeachment proceedings deinoustrates these various inanners in which impeachment inquiries originate.

Individual House members often have imitiated impeachment inquiries on their own responsibility. Generally, such a resolution would propose that "[a] committee be appointed to inquire into the official conduct of [an accused] . . . and to report their opimion whether the said [accused] hath so acted in his [official] capacity as to require the interposition of the constitutional power of the House." ${ }^{50}$ Thus, it is possible for impeachments to begin through an impeachment resolution which is adopted in reliance on the recommendation of a single House nieniber. ${ }^{51}$ For exainple, in the Johnson impeachment, one House neniber proposed as a question of privilege before the House a resolution: "That the Committee on the Judiciary be . . . authorized to inquire into the official conduct of Andrew Johnson . . . and that said committee have power to send for persons and papers and to admimister the customary oath to witnesses." ${ }^{2}$ More typically, however, impeachment inquiries have been imitiated by a proposal of one House nember reinforced by cliarges of others. Accordingly, Judge Swayne's impeachment originated in response to a inember's proposal reinforced

quirements, but rather is a flexible process which may be executed in any number of ways by a member of the House.

47. Memorials, for these purposes, include general government documents drawn from virtually any other source which provide a congressman with some motive for initiating accusations of wrongdoing.

48. "Questions of the privilege of the House are brought before the body in the form of a resolution." 6 CANNoN's $\$ \S 661-68$, at 283-84. See also id. $\S 470 ; 1$ J. STORY $\S$ 807 , at 588 .

49. 3 Hinds' $\$ 2053$. It should be noted that while a resolution directly proposing impeachment is privileged, a resolution proposing an investigation with a view to intpeachment is not. 3 id. $\S 2546$.

50. 6 CANNON'S $\S 468 ; 3$ HINDS' $\S 82051-52$.

51. See, e.g., 80 CoNG. REC. 404 (1933) (the investigation of Judge Ritter); 3 Hinds' \& 2400 (the investigation of President Andrew Johnson).

52. 3 Hinds' \& 2400 , at 824 . 
by a legislative memorial; ${ }^{53}$ the Humphreys case was initiated through a House member supported by "common fame"; 54 and Judge Louderback's impeachment originated in response to a member's proposal supported with a presentation of accusations by a local bar association. ${ }^{\mathbf{5 5}}$

Three of the earliest impeachments were initiated in response to presidental messages charging inisconduct on the part of certain imdividuals. Senator Blount's investigation was set in motion by a confidential message sent to the House by the President. ${ }^{56}$ The message set forth facts and documents which the House, by resolution, referred to a special committee for investigation. Similarly, the Pickering impeachment inquiry was imitiated in response to a inessage from the President which included several complaints froin civil officers charging the judge with official misconduct. ${ }^{57}$ Judge Archbald's impeachment investigation originated with a letter sent to the President from a mem. ber of the Interstate Commerce Commission charging the judge with official misconduct. The letter which had been sent to the President was requested by the House and transmitted to the Judiciary Committee for use in its investigation. ${ }^{58}$

Finally, in the past, not all impeachment imvestigations have been initially directed against actually named or otherwise designated individuals. The inpeachment of President Johnson was first proposed indirectly through a resolution authorizing an investigation into misconduct on the part of civil officers generally. ${ }^{59}$ Similarly, Secretary of War Belknap's impeachment grew out of an 1876 resolution authorizing a general investigation of the departments of government. ${ }^{60}$

\section{B. The Irrelevance of Probable Cause to Impeach Named Individuals}

In the Chase inipeachment, a debate arose over the sufficiency of a simgle member's supporting evidence to warrant the initiation of a full inpeachment mvestigation. Although it was urged that such an investigation should begin only upon a showing of probable cause, the House voted in favor of the investigation on the theory that such an investigation was to procure evidence and not to establish guilt. ${ }^{61}$

53. Id. \& 2469, at 949 .

54. Id. $\& 2385$, at 805 .

55. 6 CANNON's $\$ 513$, at 709.

56. 3 Hinds' § 2294.

57. $1 d . \S 2319$.

58. 6 CANNON's $\S 498$.

59. 3 Hinds' § 2399. The resolution, however, was not adopted. Id.

60. Id. $\S 2444$.

61. See, e.g., 3 Hinds' $\$ 2342$, at 712 (Chase impeachment). See also 1 J. STORY $\S 808$, at 588 . It was objected that the voting of an inquiry would be eqnivalent to the 
Nevertheless, on other occasions preliminary investigations have been initiated by the House only upon review of charges preferred by inemorial. The inipeachment proceeding in the Peck case had its official mception in a meinorial charging the judge with misconduct in office. ${ }^{02}$ Contrary to the procedure in the Chase inipeachment, in which the same issue was raised and debated, the full impeachment investigation in the Peck case was authorized only after the Judiciary Committee had examined the nnemorial for probable cause. ${ }^{63}$ Likewise, the House voted to investigate the conduct of Judge Delahay only after the Judiciary Commitee had examined charges made in a memorial. ${ }^{64}$ However, since impeachment resolutions may be sumInarily accepted or rejected for practical or political reasons without any discussion of probable cause, the only ultimate question of probability considered on such a vote is whether the investigation will probably be worth the Judiciary Committee's while. ${ }^{.5}$ Nevertheless, once instituted, an inupeachment investigation bears the crucial responsibility of procuring and preparing evidence which will support a report recommending either impeachment or no action.

\section{Investigations Preparatory to the Articles of Impeachment}

An investigation by the House has been considered to be an essential part of every impeachment to date. The importance of this preliminary investigation to the ultimate effectiveness and fairness of the overall procedure cannot be over-emphasized. It is liere that charges are investigated and facts supporting possible articles of impeachment are elicited. Consequently, the power of the investigatory committee to secure evidence relevant to its investigation cannot be separated from the impeachment power itself. ${ }^{66}$ Beginning with this preliminary stage of the impeachment process, the constitutional principle of separation of powers is conspicuously held in abeyance while the legislature gathers information necessary to exercise its exclusive constitul-

expression of an opinion that the House had evidence of the probable guilt of the judge and therefore should be entered into only with a satisfactory showing of probable cause. In rebnttal it was urged that the inqniry was to procure evidence and thus "[t]he statement of a member in his place, even thongh hearsay, was sufficient to cause inquiry." 3 Hinds' $\$ 2342$, at 713 .

62. 3 HINDS' $\$ 2364$.

63. Id.

64. Id. $\$ 2504$.

65. See, e.g., 6 CANNoN's $\$ 469$.

66. The House impeachment power may be called into full operation as soon as the House acts corporately to initiate an impeachment inquiry or investigation. 
tional power to impeach civil officers for possible wrongdoings. ${ }^{67}$

In the early impeachment cases it was common practice to select a special committee to investigate accusations of impeachable offenses brought before the House. ${ }^{68}$ Later, after the Judiciary Committee became a standing committee, it generally conducted the investigation. ${ }^{69}$ This Committee serves two purposes in the impeachment process: first, it investigates evidence bearing upon allegations of misconduct and thereupon recommends whether or not the accused should be impeached; second, it has become the practice in the more recent impeachments that the Judiciary Committee also drafts articles of impeachment to be presented at the bar of the Senate. Incident to its investigatory duties, the Committee is generally granted the subpoena power of the House to send for "papers, persons and docusnents" relevant to its inquiry.

In earlier impeachments, these two functions were assigned to two separate committees. ${ }^{70}$ One was a preliminary investigatory committee which was responsible for reporting whether or not the House should impeach the accused; the other was a committee appointed to secure information to be used in the drafting of the articles of impeachment. Although these two committees eventually came to exercise equivalent fact-finding powers, the responsibilities of the two committees were quite distinct. The preliminary investigatory committee was assigned only to satisfy itself that some basis justifying an impeachment inquiry could be identified, ${ }^{71}$ and in fairness to the accused it was generally found inappropriate to publicly defend the conclusion which the committee had reached: "In presenting the report ... the committee

67. See note 9 supra and accompanying text.

68. See, e.g., 3 Hinds' $\$ 319$ (impeachment of Judge Pickering); id. $\$ 2244$ (impeachment of Senator Blount); id. $\$ 2342$ (impeachment of Justice Chase).

It should be noted that the while the House in most instances has referred impeachment investigations to the Judiciary Committee, it has not always done so. In the Johnson impeachment, for example, the House appointed the Committee on Recoustruction to continue the investigation that earlier had been initiated by the Judiciary Committee. Id. $\$ 2408$.

69. The Judiciary Committce did not come into existence as a standing comnittee until 1813. 6 CANNoN's $\S 467$.

70. This bifurcation of the impeachment inquiry was the result of a conscious attempt to adhere to English precedent. In an early impeachnent, where it was alternatively proposed that the articles of impeachment should be prepared and presented in conjunction with the impeachment report, it was urged in rebuttal that

the mode which [was] proposed was the same which was practiced in the case

of Mr. Hastings. Mr. Burke went up to the House of Lords and impeached

him in words ..... Sonie time afterwards, the articles of impeachment having been drawn, Mr. Burke again went up to the House of Lords and exhibited them. 3 HINDS' $\$ 2295$, at 647 .

71. See, e.g., id. § 2342 (Judge Chase); id. \$2364 (Judge Peck). 
deemed it fairest toward the party accused not to report to the House their reasons at length for arriving at the conclusion that he ought to be impeached."72 In comparison, the committee assigned to draft the articles of impeachment prepared evidence in support of specific accusations of the commission of impeachable offenses. Consequently, the most extensive investigations in the early impeachments came later in the process when the articles were being drafted rather than at the prehiminary investigation stage. ${ }^{73}$

Thus, it is understandable that in the earher impeachments, where the body accomphishimg the prehminary investigation was charged only with recommending whether or not the accused should be impeached, that committee's inquisitorial authority was limited. In the Blount impeachment, for example, the investigatory committee was charged by the House only to consider the messages and papers which had been brought forth by the President and to report on impeachment therefrom $;^{74}$ then after the committee had recommended impeachment on the basis of that limited evidence, the House took additional evidence before the body as a whole prior to voting impeachment. ${ }^{75}$ The preliminary investigation of Judge Pickering was similarly focused on the examination of ex parte affidavits transmitted to the House by the President. ${ }^{78}$ In the Chase impeachment, however, the first committee was granted broader authority "to send for persons and papers" relevant to the impeachment inquiry, and smce that time, this broad fact-finding power has been delegated routinely to the investigating committee.

The earlier bifurcation of responsibilities, however, proved to be impractical in the American experience, simce the dual committee structure entails an unnecessary duplication of resources. ${ }^{77}$ Accordingly, beginning with the Archbald impeachment in 1913, whenever the Judiciary Committee has reported a resolution favoring impeachinent, it has simultaneously submitted prepared articles of impeachment supporting that resolution. ${ }^{78}$ This consolidation of the resolution and

72. Id. $\$ 2365$.

73. The committee appointed to draft articles of impeachment after the House presentation of the bare impeachment resolution at the bar of the Senate was generally empowered to procure all evidence supporting the changes. Thus, in the Blount case, it was the committee appointed to draft the articles of impeachment which was granted "power to send for persons, papers, and records." Id. $\$ 2297$.

74. Id. $\$ 2294$.

75. $I d$.

76. Id. $\$ 2319$.

77. The English have not been troubled by this problem, since the last English impeachment occurred in the eighteenth eentury.

78. 6 CANNON's $\$ 499$. The simultaneous reporting of impeachment and articles of impeachment was not original to the Archbald case. A similar reporting was proposed 
drafting functions of the investigatory committees is inherently advantageous, for otherwise, under the bifurcated system, the House nembership must vote as a whole on the question of taking to the Senate articles of impeachment which have not yet been drafted. The only apparent virtue of the separated system was to guarantee that extensive investigations would not be undertaken without the approval of the full House. But as the course of events in the Nixon proceeding now illustrates, no apparent safeguards or legislative prerogatives are lost by allowing the Judiciary Committee to proceed in its initial investigations under the mantle of the full congressional impeachment powers.

\section{The Drafting of Articles of Impeachment}

In the Nixon impeachment, the degree of specificity required in the language of the articles of impeachment was debated at length by the House Judiciary Committee. While a minority urged that due process demanded that specific articles be presented, as had always been the practice in earlier impeachment cases, ${ }^{79}$ the majority voted for articles drafted in general terms referring only to generic areas of presidential misconduct with the provision that a "list of imcidents" would be attached to the articles setting forth specific circumstances of misconduct tending to support each general article. ${ }^{80}$ In effect, the Committee resolved that since the President's counsel could demand a bill of particulars at appropriate stages of the proceeding, the past practice of specificity could be modified somewhat.

It is suggested that the Committee's decision to recommend that the House vote on general articles satisfied any applicable due process requirement and was a proper exercise of the Committee's function of recommending to the House that an impeachment trial should in any event ensue. Inasmuch as the articles serve to set the standard by which relevancy is determined in the Senate trial, ${ }^{81}$ and given the

in the impeachment of District Judge Durell in 1873. When Durell resigned, however, the impeachment proceedings were discontinned. 3 HINDs' \& 2509.

79. Although the articles in most American impeachments have been drafted to include specific instances of misconduct, it is commonly recognized that following the precedent in England, where the proceedings were strictly criminal, the articles of impeachment are distinguishable from the criminal indictment by their "less particularity of specification." 3 HINDs' $\$ 2117$. Story noted that "the articles [of impeachment] need not, and indeed do not, pnrsue the strict form and accuracy of an indictinent." 1 J. STORY § 808, at 588 (footnote omitted).

80. See the "list of incidents" compiled by connsel to the Indiciary Committee to uphold the Committee allegations in proposed impeachment Article I against President Nixon. H.R. ReP. No. 1305, 93d Cong., 2d Sess. 2 (1974).

81. The text of the articles of impeachment is, of conrse, subject to modification by the House at any time in the trial, since there is no double jeopardy or res judicata 
fact that the President had not complied with congressional subpoenas for tapes and documents pertinent to the impeachment investigation, the President should not thereby be allowed by his own derehiction to narrow the scope of inquiry in a Senate trial. The articles also provided that there could be included in the list of incidents additional information regarding misconduct, thus expediting the administration of the impeachment process without jeopardizing the rights of the accused to a fair proceeding; all of this; of course, was made necessary by Mr. Nixon's refusal to comply witl congressional fact-finding incident to its impeachment inquiry. To the extent that a President himself is responsible for creating the incompleteness of the Committee's investigation, it is unseemly for him to claim that his right to receive a fair trial is abridged either by the preliminary vagueness of the charges or by any possible over-breadth of the trial in the Senate caused by that incompleteness of evidence. Rather, it is within the power of the Judiciary Committee, reporting as the preliminary investigatory body, to recommend immediate impeachment based upon failure to comply with its constitutionally mandated fact-finding in an impeachment proceeding, thereby opening the way for further investigations and the further drafting of specific articles for subsequent presentation to the Senate.

The report of the Judiciary Committee has usually been followed by the House, but this has not always occurred. For example, in one instance the Committee recommended censure, but the House, adopting the minority report of the Committee, voted to impeach. ${ }^{82}$. Also, in the Johnson impeachment, articles in addition to those prepared and recommended by the Judiciary Committee were proposed and adopted on the floor of the House. ${ }^{83}$

\section{E. The Right of the Accused to Appear in the Course of the House Investigation}

Impeachment investigations have traditionally been conducted ex parte with the accused having a himited role, if any, in the preliminary inquiry. It has gone unquestioned that it is for the House to determine

effect in an impeachment trial. But as a practical matter, modifications will not be undertaken once the pleadings have been drafted and thus extensive pleadings and negotiations have always been important at the pleading stage of the impeachment proceeding. See text accompanying notes $175-89$ infra.

82. “ 6 CANNoN's $\$ 514$ (Judge Louderback).

83. In the Johnson impeachment, the House added two articles proposed by the newly elected managers in addition to those prepared and recommended by the drafting committee. 3 Hinds' $\$ 2418$. 
the extent of participation accorded the person under investigation. ${ }^{84}$ For these purposes, whatever sixth amendment rights to be represented by counsel and to confront one's accusers an impeached officer may have at trial before the Senate, they would not apply before the House, since it does not determine if an impeachable offense has been coinmitted. Neverthelesss, the Judiciary Committee has from time to time permitted the accused and his counsel to participate in the investigation hearings. Judge Peck cross-examined witnesses, presented a response in writing to the charges against him, and addressed the Judiciary Committee on his own behalf. ${ }^{85}$ In permitting that participation, in an effort to protect the interests of the accused, ${ }^{\mathbf{8 6}}$ the Committee expressly confined itself to what it charaoterized as ex parte evidence "lest there be no bounds to the inquiry." The effect of the Belknap impeachment upon investigatory precedent was to broaden the participation of the accused in the preliminary investigation. Belknap was allowed to present his own witnesses and was also permitted to crossexamine adverse witnesses. ${ }^{88}$ Several other impeachment cases have followed the Belknap precedent. Judge Swayne was present in person with counsel and was permitted to introduce testimony and argue his case before the Committee. ${ }^{89}$ Judge Delahay, ${ }^{90}$ Judge Archbald, ${ }^{91}$ and Judge Louderback ${ }^{92}$ each appeared with counsel before the Judiciary Committee and argued his case.

Despite the precedent for allowing a limited role for the accused and his counsel during the impeachment inquiry, the House Judiciary Committee has continued to characterize its investigation as an ex parte proceeding and House procedures do not give the accused a right to demand any role in the proceeding. As examples of the extreme to which this aspect of the procedure may be pursued, the two investigations which were conducted preliminary to President Johnson's impeachment were strictly ex parte, with only one member of the House not on the Committee being permitted to so much as examine a witness. ${ }^{93}$

In the Nixon investigatory proceeding, the accused, through counsel, was given a remarkably broad role in the Committee's hear-

84. Id. \$ 2501 .

85. Id. $\$ 2365$.

86. Id. \$ 2366 , at 779 .

87. Id.

88. Id. § 2445 .

89. Id. § 2470 .

90. Id. \$ 2504 .

91. 6 CANNON'S $\S 498$.

92. Id. $\S 514$.

93. 3 HINDS' $\S \S 2403,2409$. 
ings. ${ }^{94}$ His counsel was permitted oral and written argument, including a limited right of cross-examination, the presentation of his own witnesses, and the submission of briefs in response to proposed anticles of impeachment. However, the request of counsel that lie be allowed an advocate's role in the dehiberative process of the Committee, in addition to such participation at the faot-finding stage, was denied.

\section{F. The Burden of Proof for the Adoption of the Articles}

Another issue raised and debated in the Nixon case was the burden of proof required to sustain a vote of impeachment by the House. Despite soine precedent to the contrary, the view that the House, acting analogously to a grand jury throughout, need only ascertain probable cause to warrant sending the case to trial at the bar of the Senate has generally been followed without debate. ${ }^{95}$ Where it lias been debated, the following argunent has prevailed:

[T] he action of the House was similar to that of a grand jury; that while the investigation of the House was not necessarily ex parte, the office of the House was not to ascertain whether the party was guilty or innocent of the charges preferred against him, but whether the proof was sufficient to make the case worthy of a further trial. [A House meinber] called attention to the fact that the trial of the case belonged to the Senate under the Constitution and to the Senate alone. If the House advanccd one step beyond the ascertainment of probable cause it was plunged into the trial. The House, in the exercise of its discretion, might examine witnesses on both sides, but there must be a boundary line marking the powers of the House and Senate, and there was no line to be observed, except the ascertainment of probable cause. Such I understand to have been the views . . . entertained in the case of Judge Peck and the case of Judge Chase, of Macclesfield in 1705, in the case of Warren Hastings in 1778, and of Lord Melville in 1805.96

In the Nixon case, however, the probable cause burden was rejected, apparently not on the basis of precedent or any jurisprudential rationale, but rather as a compromise between the lesser standard of "probable cause" urged by soine and the greater burden of "beyond

94. Id. $\$ 2403$. It should be noted that while in the impeachment trial the strict rules of evidence are followed, the hearings conducted before the investigatory committee are generally less forinal. In the Johnson case, for example, the rules of evidence were relaxed at the investigatory stage of the proceeding to allow a fuller investigation: "In an investigation before a committee it would be difficult and perhaps impossible to confine the evidence to such as would be deemed admissible before a court of justice." Id. at 828. For the rules of procedure adopted by the House Judiciary Committee for the presentation of evidence concerning charges against President Nixon, see app. A infra.

95. See 3 Hinds' \& 2004.

96. Id. $\S 2498$ (debate in the Watrous investigation). 
a reasonable doubt" urged by others. The equitable burden of "clear and convincing" evidence was eventually adopted ${ }^{97}$ over the arguments in favor of a yet higher burden made by assistant minority counsel Garrison, who urged that the Committee should recommend impeachment only if it was apparent that the Senate would convict and, apart from the issue of guilt or innocence, only where the public interest would be better served should the President be convicted and removed from office.

Certainly, public policy considerations are relevant in an impeachment proceeding, ${ }^{98}$ but not in the way Mr. Garrison has urged. Impeachment was designed primarily as a ineans of protecting the Republic rather than punishing a wrongdoer. In the words of the Judiciary Committee which participated in the Colfax impeachment, the process is remedial rather than punitive. ${ }^{99}$ It follows that the impact upon the country of the final resolution of an impeachment proceeding should be a criterion of the highest order in determining the nature of its resolution. This does not mean, however, that impeachment should be used by Congress to sweep from office an unpopular President or thrat impeachment should be voted by the House only if conviction is certain to follow. The Constitution provides that before a President can be removed from office, his guilt must be established in the commission of treason, bribery, or high crimes and misdemeanors. No degree of public disenchantment with a particular President, no unpopularity of a policy, no mistake in judgment should ever be sufficient, without such guilt, to result in impeachment. Thus, public policy considerations do not mandate impeachment based upon congressional opimion but rather simply require that the House of Representatives bear the double burden of being clear and convimcing to both the Senate and the American people. If impeachment, conviction, and removal are to accomplish a therapeutic effect upon the country, it

97. In civil cases where the measure of persuasion is by a "preponderance of evidence," there are a limited number of claims in which the party is required to establish a higher burden of persuasion. The measure of "by clear and convincing evidence," represents this higher standard commonly used and seems to have had its origins in the courts of equity. See Marquis Townshend v. Stangroom, 31 Eng. Rep. 1076, 1078 (Ch. 1801); Henkle v. Royal Exch. Assurance Co., 27 Eng. Rep. 1055, 1056 (Ch. 1749). Equity cases on the degree of proof necessary to establish a claim are collected in C. MCCORMICK, HANDBOOK OF THE LAW OF EVIDENCE $\$ 340$ (2d ed. E. Cleary 1972).

98. [I]f "broad and comprehensive principles of public policy" are appropriately considered in the profoundly political process of impeachment, then the impact upon the nation of the President's removal or retention is valid consideration, even though such considerations would be inappropriate in a forum charged with the normal "judicial function" of deciding guilt or innocence without regard for political consequeuces. Firmage, supra note 14, at 700 .

99. 3 HINDS' $\$ 2510$. 
is essential that the public be convinced of the President's guilt in the commission of impeachable offenses and thereby be persuaded that his removal is in the constitutional interest of the country. The citizenry must not only be convinced of this but must also be convinced in bipartisan numbers if impeachment is to be dominantly therapeutic rather than divisive. It is not sufficient that Congress only be convinced, and it is toward the accomplishment of this harmony between the electorate and its representatives that the issue of television coverage of impeachment proceedings will be considered.

Comparisons between impeachment proceedings and criminal trials, in which only the issue of guilt or innocence is relevant and in which no particular public acceptance of an individual verdict is necessary, are therefore inapt. ${ }^{100}$ It is here, in the necessity of bearing a double burden of convincing the people, in addition to the usual burden of persuading designated triers of fact and law, that the burden of proof for an impeachment proceeding must be defined. It does indeed place a huge burden on those advocating impeachment, a burden which is qualitatively different from that found in the usual judicial proceeding.

\section{G. The Public Eye on the Adoption of the Articles of Impeachment}

In the early cases where the voting of impeachment and the drafting of the articles were separate functions, the committee drafting the articles was under an injunction of secrecy, which was removed only at the time the articles were presented before the House. ${ }^{101}$ Today, however, the drafting of the articles of impeachment has taken on a more significant role as the first official act to be completed in the impeachment process, thereby setting the scope and tone for the entire impeachment process to follow.

In the Nixon impeachment proceeding, although the fact-finding process of the Judiciary Committee was intended to be secret, the Committee, convinced that the nation would be well served with rapid public disclosure of congressional impeachment decisions, whatever they might be, amended its rules to allow television coverage of its deliberations over the particular articles of impeachment. The legitimacy of a democratic government must be establislied in the minds of the people; ${ }^{102}$ thus, if a transfer of presidential power is to be accomplished by either removal or resignation in the face of impeachment, the legitimacy of the new administration can only be assured by public rec-

100. Firmage, supra note 14, at 703.

101. See, e.g., 3 HINDs' $\S \S 2300,2323$.

102. See note 3 supra. 
ognition that the previous mandate has clearly expired. In order for this to occur, whatever interests previously were served in the name of fairness to the accused by insisting on secrecy in the adoption of the anticles of impeachment must yield to the public interest when a public office, which derives its imprimatur from the public will, is in question. ${ }^{103}$

\section{H. The Committee Report on the Articles of Impeachment}

The investigatory committee culminates its hearings by voting on recommendations of impeachment. Generally, in the early impeachments, the investigatory committee thereafter reported its conclusions to the Committee of the Whole House. ${ }^{104}$ Where the investigation committee recommended impeachment and the Committee of the Whole concurred, an impeachment resolution was presented before the House for the impeachment vote. In these earliest impeachments minority views were not permitted to appear in the committee's report, and any dissent appeared only in the debates. ${ }^{105}$ Furthermore, as noted previously, the committee was charged only with reporting its conclusions to the House, and thus it usually excluded any reasons for its conclusions in fairness to the accused. ${ }^{106}$ Later, the Judiciary Committee came to report its recommendation directly to the House. ${ }^{107}$

Beginning with the Johnson impeachment in 1868, majority and mimority arguments were included in the committee's report. ${ }^{108} \mathrm{Al}-$ though in the first attempt to impeach the President, the majority of the investigatory committee recommended impeachment, the House apparently favored the minority argument and the resolution failed. ${ }^{109}$ When the Committee on Reconstruction, after a second investigation, recommended impeachment, with no minority argument being filed, ${ }^{110}$

103. This is not to imply that no impeachment of a judicial officer should be publicized, but only that mass media coverage of an impeachment of, for example, a Supreme Court Justice would have to be justified on some other grounds.

104. See, e.g., 3 HnNDs' 2319 (Pickering); id. § 2343 (Chase); id. § 2365 (Peck). In the Blount case, however, the articles were presented directly to the House. Id. $\S$ 2300 .

105. Id. $\$ 2343$, at 716 (A committee member in debate dissented from the committee's report to impeach Justice Chase on the grounds that testimony given had been "entirely ex parte.").

106. Id. \& 2365.

107. See, e.g., 6 CANNON's $\$ 498$ (Archbald); id. § 514 (Louderback); 3 Hinds' $\S$ 2385 (Humphreys); id. $\$ 2410$ (Johnson); id. \$ 2445 (Belknap); id. $\$ 2505$ (Delahay).

108. 3 HINDs' \& 2403 .

109. Id. § 2407.

110. Although several members of the Committee dissented from the majority report, they did not present any minority report in support of their views. Id. $\S 2410$, at 847 . 
the House voted to impeach. ${ }^{111}$

\section{The Vote on the Articles on the Floor of the House}

Historically, presentation of the articles on the floor of the House has involved issues of both strategy and fairness. In the Blount and Pickering cases, the articles were considered collectively, but in the Chase impeachment the articles were presented individually both to the Committee of the Whole and before the House. ${ }^{112}$ In that impeachment, the House debated whether or not additional articles could be proposed at any time; in concluding that they could, the House expressly "saved to itself the liberty of exhibiting at any time hereafter any further articles of other accusation or impeachment ...."113 There is precedent in other cases for presenting the articles together to be adopted without debate, ${ }^{114}$ and there are instances, such as the Swayne impeachment, where a strong minority report and accompanying debate immediately preceded the vote to adopt the articles. ${ }^{115}$ in the Swayne impeachment, the minority dissented from the inajority's report of twelve articles on the ground that a "beyond reasonable doubt burden had not been inet on eleven of the articles."116 Following House amendment of some of the articles, they were presented individually and adopted by the House. ${ }^{117}$

Beginning with the Belknap impeachment the practice of presenting the articles first to the Committee of the Whole was dispensed with without any question being raised as to the propriety of having the articles presented directly to the House by the House Judiciary Committee. ${ }^{118}$ In this inanner, the power of the Judiciary Committee was enhanced, and the discretion of the whole House regarding rules of debate and amendment was correspondingly limited. In the Belknap case, the articles were adopted without amendment, a separate vote not being deinanded on any article. ${ }^{119}$ In the Johnson case, after the articles had been adopted individually, the nnanagers who were elected to present the articles at the bar of the Senate proposed two additional articles to broaden the charges to include non-indictable offenses. ${ }^{120}$

111. Id. § 2412 .

112. $I d . \S 2344$.

113. Id. at 719.

114. See, e.g., id. $\S 2448$ (Belknap).

115. Id. § 2474 .

116. Id.

117. Id. The articles may be amended on the floor of the House without being referred back to committee, as the Pickering proceeding illustrates. Id. $\S 2324$, at 686 .

118. Id. $\S 2448$, at 908 .

119. Id.

120. $I d . \S 2418$. 
In the Archbald impeachment, the practice of reporting the articles of impeachment simultaneously with the impeachment resolition was initiated. There the report of the Judiciary Committee was debated in the House, and the supporting articles of impeachment were voted on together with the impeachment resolution. ${ }^{121}$ Both the English and the Louderback impeachments followed the Archbald pattern. In the English case, the House after debate accepted the procedure that "[i]t is in order to demand a division of the question on agreeing to a resolution of impeachment and a separate vote may be had on each article."122 In the Louderback case, the articles adopted were those presented as the minority report favoring impeachment. ${ }^{123}$

\section{J. The Effects of Recesses and Adjournments on the Impeachment Process}

Impeachment proceedings in the Umited States have followed the parliamentary precedent that an impeachment is not terminated or legally interrupted by the dissolution of Parliament. ${ }^{124}$ Accordingly, the House has often continued inipeachment investigations froin one session to another, making use of any former report or testimony already taken; similarly there is nothing to prevent a Senate trial initiated in one session of Congress froin being continued in the next until a verdict is reached.125 The following examination of precedent demonstrates the continuity of Congress' constitutional responsibility of impeachment.

From the earliest impeachment, that of Senator Blount, the precedent has been firmly established that an impeachment is unaffected by congressional recesses or adjournments. In that case, Congress recessed between the impeachment of Blount and the framing of the articles of impeachment. ${ }^{126}$ Later the Senate, in its writ of summons, fixed Blount's appearance at the next session of Congress. ${ }^{127}$ In the impeachment of Pickering, the House proceeded even though it was

121. 6 CANNON'S $\$ 500$.

122. Id. $\$ 545$.

123. Id. $\$ 515$.

124. 3 Hinds' $\$$ 2004-05. . See also Manual $\S 620$, at 305.

125. In respect to the procedure in the House, see 3 Hinds' $\S 2029$ (Boarman). The Senate has continuing jurisdiction over an impeachment trial and could continue a trial between sessions even though some new Senators were present. In several trials, however, new meinbers were excused from voting on the judgment of impeachment cases because they had taken their seats after part of the testimony had been given. See, e.g., id. \$2114 (Swayne); id. \& 2396 (Humphreys).

126. Id. $\$ 2299$.

127. Id. $\$ 2304$. 
apparent that the impeachment could not be completed within that congressional session. ${ }^{128}$ Accordingly, the House continued with the proceedings, impeaching Pickering and notifying the Senate on the last day of the Seventh Congress. Thereafter, at the beginning of the Eighth Congress, the House appointed a committee to prepare articles of impeachment to continue the proceeding. ${ }^{129}$ Similarly, the House voted the impeachment of Judge Delahay at the end of one Congress, intending to present articles of impeachment in the next. ${ }^{130}$ Congress also recessed between the filing of the answer in the Peck impeachment and the managers' presentation of the replication. ${ }^{131}$ No reason in precedent or public policy would seem to exist for distinguishing between presidential impeachment and the impeachment of civil officers in regard to this point. ${ }^{132}$ In the Johnson impeachment, the Thirty-ninth Congress expired during the preliminary investigation, and in the next Congress, the House directed the Judiciary Committee to resume the investigation. ${ }^{133}$ Later, Congress recessed after receiving the Committee's report recommending impeachment, and the subsequent session of the House voted on the report. ${ }^{134}$ Thus, an impeachment proceeding should not be affected by recesses or adjournments of Congress.

\section{K. The House Selection of Managers}

The House lias varied both its method for selecting its managers and the number of managers selected to present its case at the bar of the Senate. ${ }^{135}$ Managers liave been selected by ballot, appointed by the House Speaker, and selected by resolution. In the Blount impeachment, eleven managers were elected by ballot following House debate which analyzed the comparative roles of the managers and normal committees of Congress. The election procedure was wisely adopted in the Blount case, contrary to the ordinary practice of laving inves-

128. Id. $\S 2319$.

129. Id. $\S 2321$.

130. Judge Delahay's resignation prior to the beginning of the next Congress apparently caused the House to discontinue the impeachment. Id. § 2505 .

131. Id. $\$ 2375$.

132. Cf. Firmage, supra note 14, at 700 (suggesting a different standard of conduct for an impeachable offense).

133. 3 HINDs' \& 2401, at 825. The resolution was adopted forthwith, and the congressional session having expired before the completion of the investigation, a member of the House proposed as a question of privilege at the beginning of the next session that the Judiciary Committee complete the investigation begun earlier.

134. Id. $\$ 2407$.

135. 6 CANNON's $\$ 467$. 
tigatory committees appointed by the Speaker, due to a recognized difference of broader non-partisan responsibility to be fulfilled by those selected as inanagers. Whereas the reports of the investigatory conmittees are not finally binding upon the House, the conduot of the managers serves as an ultimate representation of the House, with any action taken by them being final. Thus, the managers, by House resolution, were elected individually by ballot with each manager requiring a majority to be elected. Following the Blount precedent, managers have been elected by ballot in the Pickering, ${ }^{136}$ Chase, ${ }^{137}$ Peck, ${ }^{138}$ and Johnson cases. ${ }^{139}$ In the subsequent proceedings, however, managers were appointed either by resolution ${ }^{140}$ or by the Speaker. ${ }^{141}$

Excepting the Blount impeachment, where all eleven managers were from the Federalist party, the inanagers have represented both panties. Of course, it has always been the practice that the managers, as advocates of the House, would refleot the House sentiments ${ }^{142}$ regarding impeachment. Accordingly, managers have always been selected from among those who have voted in favor of impeachment. The chairman for the managers has been selected by the managers in some cases ${ }^{143}$ and by the House in others. ${ }^{144}$

Usually, the managers have the responsibility of presenting the anticles of impeachment against the accused at the bar of the Senate and of conducting the case of the House at the Senate trial. In charging the managers with the responsibility of conducting the case before the Senate, the House normally delegates further fact-finding powers to the managers incident to their prosecutorial duties. ${ }^{145}$

Upon informing the Senate that the House of Representatives "will, in due time, exhibit panticular anticles against [the impeached]

136. 3 HnNDs' $\$ 2323$ (eleven managers elected).

137. Id. $\$ 2345$ (seven managers elected).

138. Id. $\$ 2368$ (five managers elected).

139. Id. § 2417 (seven managers elected).

140. See, e.g., 6 CANNON'S $\$ 500$ (seven managers appointed by resolution in the Archbald impeachment); id. $\$ 514$ (five managers appointed in the Louderback impeachment); 3 Hinds' $\$ 2388$ (five managers appointed by resolution in the Huinphreys impeachment); $i d$. $\$ 2448$ (seven managers appointcd by resolution in the Belknap impeachment).

141. See 3 HnNDs' \& 2475 (The Speaker of the House in the Swayne impeachment appointed seven managers.).

142. See id. § 2448 (Belknap).

143. See id. \$ 2417 (Johnson).

144. See id. $\$ 2448$ (Belknap).

145. See id. § 2419 (Johnson). 
and make good the same,"146 the managers demand that the Senate "take order for [his] appearance ... to answer the said impeachment."147

\section{SeNate IMPEACHMENT PROCEDURE}

The Constitution vests in the Senate the sole power of trying all impeachments, ${ }^{148}$ but as to the form and nature of the impeachment trial the Constitution is silent except for the following statements. The Constitution provides that "[w]hen the President of the United States is tried, the Chief Justice shall preside: And no Person shall be convicted without the Concurrence of two thirds of the Members present."140 The Constitution further strips from the impeachment process the power to impose any criminal sanctions; at the same time, it assures that any convicted party shall not be beyond the normal operations of the criminal law either during or subsequent to the impeachinent process. ${ }^{150}$ Finally, the Constitution provides that the President's power to grant reprieves and pardons for offenses against the United States does not extend to cases of impeachment ${ }^{151}$ and that the right to trial by jury extends to all crimes except cases of impeachment. ${ }^{162}$ Due to the constitutional silence in regard to all other aspects of the impeachment trial, we must turn to an analysis of prior precedents in order to ascertain the working elements of Senate procedure in impeachment trials.

\section{A. Does the Senate Sit as a Court?}

The selection of criteria by which the appropriateness of any aspect of the Senate procedure in an impeachment trial is to be judged depends in large part upon whether the proceeding is to be seen as being dominantly political or juridical. But either characterization of the process is problematic, since many judicial practices are appropriated by the Senate for use in the impeachment trial, which is otherwise conducted as a wholly political proceeding. Its adjudicative nature is manifest especially in the conduct of the impeachment trial, its rules

146. $I d . \S 2296$.

147. Id.

148. "The Senate shall have the sole Power to try all Impeachments." U.S. CoNST. art. I, $\S 3$, cl. 6 .

149. Id.

150. "Judgment in Cases of Impeachment shall not extend further than to removal from Office [and] the Party convicted shall nevertheless be liable and subject to Indictment, Trial, Judgment, and Punishment according to Law." Id. art. I, § 3, cl. 7 .

151. Id. art. II, § 2, cl. 1 .

152. Id. art. III, $\S 2$, cl. 2. 
of evidence, the form of judgment, and in the absence of judicial review over the impeachment process. On balance, however, American precedent reflects the basic understanding that the impeachment process is fundamentally political.

In the early impeachment cases, although the Senate described itself by rule as a court of impeachment, ${ }^{153}$ the powers which it invoked were described as political powers and privileges. In one case, the issue of characterizing the impeachment process arose in argument over the assertion that the Senate's impeachment jurisdiction does not extend to an offense which is within the jurisdiction of the common law courts. Mr. Bayard, one of the managers in the Blount impeachment, answered persuasively that the role of the Senate in impeachment cases is political rather than judicial since "no court at common law could give judgment of disqualification, and that was the just punishment for the offense alleged." 154

It was suggested as early as the Pickerimg impeachment that the Senate had the sole power to regulate forms, substances, and proceedings when actimg as a court of impeachment. ${ }^{155}$ In the Johnson impeachment in 1868, the Senate, after substantial debate, decided that it sat for impeachment trials as the Senate and not as a court. ${ }^{158}$ The debate appears to have been initiated in response to a resolution to drop the words "high court of impeachment" froin its Senate rules lest the Chief Justice might have a tie-breaking vote on procedural questions. ${ }^{157}$ The resolution passed and the Senate adopted rules for the Johnson trial as a Senate and not as a court. ${ }^{158}$ After the trial concluded, Senator Sumner, a bitter enemy of Johnson, elaborated on the political nature of the proceeding by explaining that Senators are not constrained in impeachment by any obligation to serve the traditional role of a criminal trial judge:

[The Constitution] provided that "the Senate shall have the sole power to try all impeachments," thus positively making a distinction between the judicial power and the power to try impeachments; . . . the Senate on an impeachment does not exercise any portion of the judicial power, but another and different power, exclusively delegated to the Senate,

153. See, e.g., 3 Hinds' $\$ 2307$ (Blount). See also $1 \mathrm{~J}$. STORY $\$ 809$.

154. 3 HINDs' $\$ 2314$. See also 1 J. STORY $\$ \S 800,812$.

155. 3 HINDS' \& 2324.

156. Id. § 2057.

157. Id.

158. Id. Chief Justice Chase, however, presented a written dissent from the views taken by the Senate with regard to its constitutional function as a political body rather than as a court in an impeachment trial. Id. 
having for its sole object removal from office and disqualification therefor; ... the proceeding by impeachment is . . . from beginning to end political, being conducted before another political body having political power only, and ending in a judgment which is political only. ${ }^{159}$

Later in the Archbald case, the issue of the proper role of the Senate in an impeachment trial was again raised and debated:

[M]uch has been attempted by counsel for the respondent in their effort to show that this is a court im the ordinary acceptance of that term. Whatever naine you call this body sitting here now, whatever functions they may discharge, it cannot be said to be a court as that word is employed in the Constitution or understood by the ordinary man. It is inore than a court. Under our Government it is clothed with the highest and most extraordinary powers of any body or any functionary or any agency of our Federal Government. Your powers here invoked are political in their nature. Mr. Bayard announced that doctrine in the first impeachment case, that of Blount. Every commentator, including Story and all the rest, lias quoted it with approval, and should any man deny it he would at once confess himself ignorant of the history and the law of impeachment. ${ }^{160}$

If this conclusion were not reached and were the verdict of the Senate trial not reviewable by the federal courts, ${ }^{101}$ the exercise of judicial power by the Senate would appear to violate the vesting of the judicial power of the United States in one Supreme Court. ${ }^{162}$

Accordingly, it is generally understood that the Senate functions as a political body in impeachment trials, exercisnig its political duty in a political nuanner and to a political end. Several conclusions follow fron this proposition. First, the Senate and not the judiciary is charged with adopting rules with respect to the conduct of impeachnient trials. ${ }^{163}$ Second, as a matter of public policy, rules of admissibility of evidence in an impeachment trial need not necessarily comply strictly with judicial exclusionary rules designed to protect the integrity of the judicial process, particularly those designed to insulate a jury in a criminal trial. Third, the rules of evidence adopted by the Senate are subject to nodification on an ad loc basis where the Senate deems

159. Id. $\$ 2057$, at 385 .

160. 6 CANNON's $\S 471$, at 665 .

161. See section VII accompanying notes 310-31 infra.

162. U.S. ConsT. art. III, $\S 1$.

163. New impeachment trial rules were proposed for the Peck trial, 3 HiNDs' \& 2372, the Archbald trial, 6 CANNON's $\S 483$, and recently for the Nixon trial, S. Res. 390, 93d Cong., 2d Sess. (1974), but in each of these cases the proposed new rules were rejected and the rules framed in the earliest impeachment cases continued in effect. 
it appropriate. ${ }^{164}$ Fourth, judicial review is inapplicable to the impeachment process and judgment.

\section{B. Initation of the Senate Trial}

The House, by notifying the Senate that it has impeached a civil officer, formally sets in motion the impeachment trial machmery of the Senate. Notification in the earlier impeachments was transmitted to the Senate by a committee of two or three appointed for that purpose, which made formal accusations on behalf of the House and signified that articles of impeachment would later be exhibited. ${ }^{165}$ In some instances, the Senate has organized for trial before receiving the articles, ${ }^{166}$ but in other cases it has organized only after the articles have been presented. ${ }^{167}$ Upon presentation of the articles, the Senate is required by its own rules to proceed to prompt consideration. ${ }^{168}$ In presenting the articles of impeachment at the bar of the Senate, ${ }^{169}$ the chairman of the House managers generally reads the articles and then delivers thein at the table of the Senate. ${ }^{170}$ In organizing for trial, the Senate suspends ordinary business, administers oaths to the Senators, ${ }^{171}$

164. The Senate amended some of its existing rules and added other rules in the Johnson trial. 3 Hinds' $\$ 2414$. Also, additional rules were adopted by the Senate for the trial of Judge Louderback. 6 CANNoN's $\$ 519$.

165. See, e.g., 3 Hinds' $\$ 2294$ (A single House member notified the Senate that Blount had been impeached by the House.). The Pickering impeachment was carried to the Senate by a committee of two. Id. $\$ 2319$. For other cases in which impeachment resolutions were carried to the Senate by a committee of two, see id. $\$ 2343$ (Chase); id. § 2367 (Peck); id. § 2385 (Humphreys); id. § 2412 (Johnson); and id. § 2505 (Delahay). See generally 1 J. STORY \$ 807.

166. In the Blount impeachment, the Senate "took order for the trial" upon the presentation of the impeachment resolution. 3 HINDs' § 2296; accord, id. §§ 2325, 2328 (Pickering). See also $1 \mathrm{~J}$. STORY \& 807.

167. In the Pickering case, the Senate concluded that there was no impeachment before the Senate until the articles of impeachment were exhibited. 3 Hinds' $\$ 2324$; accord, id. \& 2450 (Belknap).

168. See, e.g., 6 Cannon's $\$ 546 ; 3$ Hinds' $\$ 2079$. See also Senate Impeachment RULE III, app. B infra; $1 \mathrm{~J}$. STORY $\$ 807$.

169. See, e.g., 3 HINDs' § 2301 (Blount); id. \$ 2328 (Pickering); id. § 2346 (Chase); id. $\$ 2369$ (Peck); id. § 2389 (Humphreys); id. \$2420 (Johnson); id. \$ 2449 (Belknap); id. $\$ 2476$ (Swayne).

170. See, e.g., 6 CanNon's $\S 501$ (Archbald); 3 HINDs' $\$ 2328$ (Pickering); id. $\S$ 2346 (Chase); id. § 2420 (Johnson); id. \$2449 (Belknap).

171. Senators sitting for an impeachment trial are required by the Constitution to be on oath or affirmation. U.S. CoNST. art. I, § 3. Until 1876 the Senate under its own rules empowered its presiding officer to administer to Senators the oath required for an impeachment trial. In the Belknap trial, the oath was initially admimistered by the Chief Justice, but during the trial a bill was enacted conferring on the presiding office authority "to administer all oaths or affirmations that are or may be required by the Constitution or by law to be taken by any Senator, officer of the Senate, witness, or 
assumes jurisdiction by majority vote, ${ }^{172}$ appoints a presiding officer, ${ }^{173}$ and notifies the House of Representatives that the Senate is ready to proceed. ${ }^{174}$

Once the articles have been presented and the Senate organized for trial, the managers generally demand that process be issued against the accused to appear and answer the charges presented by the House. ${ }^{175}$ The writ of summons which is issued by the Senate recites the articles of impeachment and notifies the respondent to appear at a fixed time and place and to file an answer. ${ }^{178}$ Where respondent fails to appear or to answer either in person or by counsel, ${ }^{177}$ the trial proceeds as on a plea of "not guilty."178 The respondent is usually allowed to appear and move for a delay in the filing of his answer, but requests are often not accepted. ${ }^{179}$

In answering, the respondents have either (1) taken articles one by one, denying some of the charges, admitting others but denying that they set forth impeachable offenses, and excepting to the sufficiency

other person, in respect to any matter within the jurisdiction of the Senate." 3 HrNDs' $\$ 2081$, at 412 . Subsequently, a Senator is designated by resolution to administer the oath to the presiding officer, who in turn administers the oath simultaneously to all Senators standing in their places. See, e.g., 6 CannoN's $\$ 502$ (Archbald). The Senate in its rules has refrained from prescribing an oath for the Chief Justice when he presides at an impeachment trial. 3 Hinds' $\$ 2079$; see Senate Impeachment RULEs III, IV, app. B infra.

172. 3 HINDs' \& 2059.

173. Generally, the President pro tempore of the Senate presides in impeachment trials against all civil officers except the President. Where the President pro tempore is unable or unwilling to preside at trial when it is his duty, a presiding officer is appointed by resolution. See 3 Hinds' $\& 2477$ (Swayne). In presidential impeachment, the Chief Justice of the Supreme Court presides in accordance with the constitutional requirement. See U.S. ConsT. art. I, \& 3.

174. 3 Hrnds' $\& 2070$. See also $1 \mathrm{~J}$. STORY $\$ 811$.

175. 3 HINDS' $\S 2127$; see, e.g., 6 CANNoN's $\S 503 ; 3$ HINDs' $\$ 2423$ (Johnson); id. $\S 2478$ (Swayne); id. \$2451 (Belknap). See also $1 \mathrm{~J}$. STORY $\$ 807$.

176. 3 HrNDs' $\S 2127 ;$ see, e.g., id. $\$ 2304$ (Blount); id. \$ 2329 (Pickering); id. § 2347 (Chase). See also $1 \mathrm{~J}$. STORY § 807.

177. 3 HnNDs' § 2127 . Justice Chase appeared "in his own proper person," id. § 2349, and Judge Peck attended in person and by counsel, $i d$. $\$ 2371$. Johnson entered his appearance by a letter addressed to the Chief Justice, which named a counsel who would appear for him. Id. \$2424. See also $1 \mathrm{~J}$. STORY $\$ 809$.

178. 3 HINDS' $\$ 2127$.

179. The Senate declined to allow Judge Peck to delay his answer until the next session of Congress and set an earlier date for filing an answer than he had requested. 3 id. \$ 2371. The Senate also denied President Johnson's request for forty days in which to prepare an answer and instead granted ten days. Id. \$\$ 2424-25. The Senate, on the other hand, has allowed reasonable requests for time to prepare an answer. For example, the Senate has granted motions by respondents that ten days be granted for the purposes of answering the impeachment charges. See, e.g., 6 CANNon's $\$ \$ 482,504$ (Archbald). 
of others, ${ }^{180}$ (2) demurred to the articles generally, raising a question as to the jurisdiction of the Senate to try the charges, ${ }^{181}$ or (3) demurred severally to all the articles and then replied in detail to the cliarges set forth in eacli article. ${ }^{182}$ It has been commonly lield that the answer of respondent under the parliamentary law of impeachment need not observe neat strictness of form, ${ }^{183}$ just as the articles need not be as specific as an indictment. If a guilty plea is entered in answer, judgment inay be entered without further proceedings. ${ }^{184}$ Otherwise, a Senate trial must follow to a final conviction or acquittal.

Upon receiving the respondent's answer, time is allowed for the replication of the inanagers, on the condition that any further pleadings be duly filed with the Secretary and notice be given to the other party prior to a designated date. ${ }^{185}$ A replication by the House managers usually consists of a general demial of all allegations set forth in the respondent's answer and of an averment that the charges contained in the articles set forth impeachable offenses. ${ }^{186} \mathrm{~A}$ replication, on the other hand, can allege a new inatter not set forth in the articles, ${ }^{197}$ thereby necessitatimg further pleadings. ${ }^{188}$ The parties may submit briefs in support of their pleadings, but the briefs typically are not submitted until after the inanagers and counsel for the respondent have made opening statements and introduced witnesses at the Senate trial. ${ }^{189}$

The time granted by the Senate for the respondent to prepare for trial after presentation of his answer will vary, but the Senate usually allows the question of calendaring to be argued by both sides. President Johnson, for example, requested 30 days, and arguments were heard on the inotion with the Senate granting less time ${ }^{190}$ and suggesting that there should be no delays once trial was commenced. ${ }^{191}$ In the Nixon case, counsel for the respondent was notified by the Senate, after the Judiciary Committee had voted to report articles of impeachment to the

180. 3 HINDs' $\$ 2428$ (Johnson).

181. See, e.g., id. \& 2453 (Belknap demurred to the imepachment articles on the grounds that he was not a civil officer.).

182. See, e.g., 6 Cannon's $\$ 505$ (Archbald).

183. 3 HINDS' \$ 2121. See also Jefferson's Manual § 620, at 305.

184. 3 Hinds' \& 2127. See also Senate Impeachment Rule VII, app. B infra.

185. See, e.g., 6 Cannon's $\$ 547$ (English). In the Belknap trial the forms of pleading, including rejoinder, surrejoinder, and similiter, were discussed. 3 HrNDs' $\$ 2455$.

186. See, e.g., 6 CANNON's $\$ 507$ (Archbald).

187. See, e.g., 3 Hinds' \& 2454 (Belknap).

188. Id. $\$ 2455$ (Belknap).

189. See, e.g., 6 CANNoN's $\S 480$ (Archbald); 3 Hinds' $\$ 2125$ (Swayne).

190. 3 HINDs' $\$ 2430$.

191. Id. 
House, that the President would be granted two to three weeks for the preparation of the case should the House vote impeachment.

\section{The Presiding Officer}

The presiding officer during Senate impeachment proceedings is the Vice-President and, in his absence or own trial, the President pro teinpore, ${ }^{192}$ except in cases involving the President, where the presiding function is performed by the Chief Justice of the United States. ${ }^{103}$ The presiding officer is empowered by rule to make and issue orders, writs, precepts, and regulations, ${ }^{104}$ and to direct the form of proceedings for which the rules otherwise have not provided. ${ }^{195}$ All motions by the parties are to the presiding officer, ${ }^{196}$ who sometimes makes preliminary rulings on evidentiary issues and instructs and interrogates witnesses. ${ }^{197}$ The preliminary rulings of the presiding officer stand as judgments of the Senate unless a vote is requested by a Senator ${ }^{108}$ and the Senate thereafter overrules the preliminary ruling. ${ }^{109}$

The role of the Chief Justice as the presiding officer in a presidential impeachment is unsettled at least as to whether he is entitled to a tie-breaking vote on procedural questions. Although Chief Justice Chase voted on minor procedural issues in the Johnson trial, ${ }^{200}$ the propriety of his doing so was not conclusively settled. ${ }^{201}$ Nevertheless, since we must infer that, where the impeachment rules are silent, the general Senate rules of procedure apply, ${ }^{202}$ the presiding officer should

192. Id. § 2309 (Blount); id. \$2337 (Pickering); id. \$2477 (Swayne). See also $i d$. $\$ 2394$ (In the absence of the Vice-President, the President pro tempore presided in the Humphreys case.).

193. U.S. CoNST. art. I, § 3. See also 3 HINDS' §§ 2055, 2082.

194. 3 HINDs' \$ 2083. See also SENATE IMPEACHMENT RULE V, app. B infra.

195. See, e.g., 3 Hinds' $\& 2331$ (Pickering). See also Senate Impeachment Rule $\mathrm{V}$, app. B infra.

196. 3 Hinds' \$ 2131. See also SENATE IMPEAChMENT RUle XVI, app. B infra.

197. 3 Hinds' \$\$ 2085-87. See also Senate Impeachment RUle XIX, app. B infra.

198. The right to challenge the presiding officer's preliminary rulings belongs to the Senators and to couusel. See, e.g., 3 Hinds' $\$ 2195$ (where the President pro tempore as presiding officer in the Belknap trial held that counsel for respondent could not appeal a preliminary ruling to the Senate although a Senator might have the point submitted to the Senate). In the Johnson trial, Chief Justice Chase held that the managers might not appeal from a decision of the presiding officer as to evidence. $I d . \$ 2084$.

199. Id. For instances where the presiding officer has made evidentiary decisions, see $i d$. $\$ \S 2226-29,2252,2271,2276$. For instances where a presidiug officer's preliminary ruling was overruled by the Senate, see $i d . \$ \S 2208,2222,2238$.

200. Id. $\$ 2067$.

201. Id. § 2098.

202. Id. $\$ 2100$. For a discussion of the form and history of the Senate Rules applicable to impeachment trials, see the following sections in 3 HINDs'; $\$ 2078$ (Rule I); 
be entitled to exercise a tie-breaking vote on questions of procedure unless his power is otherwise limited.

\section{Conduct of the Impeachment Trial}

The Senate sits for an impeachment trial with open doors but conducts secret sessions when deliberating on any decision, ${ }^{203}$ be it an evidentiary ruling or the final judgment. However, the final judgment has been considered on occasion in open session. ${ }^{204}$ Thus, as a general rule the orders and decisions of the Senate trial are debated in closed session, but the Senate by majority vote can proceed with debate in open session. ${ }^{205}$ All motions must be presented in writing to the presiding officer, ${ }^{206}$ and any question or remark of a Senator must be similarly presented. ${ }^{207}$

Impeachment trials are exempted from the constitutional requirement of trial by jury. ${ }^{208}$ The trial is imitiated by each side making an opening statement, ${ }^{209}$ which generally (1) outlines what is expected to be proven or rebutted, (2) discusses constitutional questions, and (3) controverts or defends charges preferred in the articles of impeachment. $^{210}$ During the impeachment trial, all preliminary or imterlocutory

§ 2126 (Rule II); § 2079 (Rule III); § 2082 (Rule IV); \& 2083 (Rule V); § 2158 (Rule VI); § 2084 (Rule VII); § 2127 (Rule VIII); § 2128 (Rule IX); § 2129 (Rule X); § 2070 (Rule XI); § 2069 (Rule XII); § 2090 (Rule XIII); \$ 2130 (Rule XIV); § 2131 (Rule XV); § 2168 (Rule XVI); § 2163 (Rule XVII); § 2176 (Rule XVIII); § 2075 (Rule XIX); §§ 2091-93 (Rule XX); § 2132 (Rule XXI); § 2098 (Rule XXII); § 2094 (Rule XXII); §§ 2080, 2119, 2162 (Rule XXIV); § 2076 (Rule XXV).

203. Id. $\$ 2075$. See, e.g., 6 CanNon's $\S 524$. (In the Louderback case the Senate deliberated in secret session on the final judgment.); 3 Hinds' $\$ 2309$ (In the Blount case all questions were decided in secret session and by yea and nay votes.); $i d$. $\$ 2437$ (In the Johnson trial deliberation on the final question was couducted in secret session.). See also Senate IMPEACHMENT RULes XX, XXIV, app. B infra.

204. See, e.g., 3 Hinds' 2383 (Peck); id. \$ 2397 (Humphreys).

205. Id. $\$ 2094$. The rule that decisions of the Senate sitting for an impeachment trial shall be without debate has been rigidly enforced. Id. § 2088; cf. id. \$ 2154 (In the Swayne trial, the Senators were permitted to debate to a greater extent than usual.). Debate in secret session is limited to ten minutes on interlocutory questions and to fifteen minutes on the final question, unless modified by consent of the Senate. Id. § 2094. See also Senate IMPEACHMENT RULE XXIV, app. B infra.

206. 3 HINDS' \& 2131. See also SENATE IMPEACHMENT RULe XVI, app. B infra.

207. See 6 Cannon's $\$$ 519. See also Senate Impeachment RULE XIX, app. B infra.

208. U.S. CoNst. art. III, $\$ 2$, cl. 3.

209. See, e.g:, 6 CANNoN's $\S 522$ (Louderback); 3 Hinds' $\$ 2132$ (Johnson). See also SENATE IMPEACHMENT RULE XXII, app. B infra.

210. See, e.g., 6 CanNoN's $\$ 509$ (Charges preferred in the articles were controverted in the opening address of respondent's counsel in the Archbald case.); 3 Hinds' $\S 2133$ 34 (The managers in the Swayne case outlined in their opening statements what it was 
questions and motions are limited to one-hour arguments on each side. ${ }^{211}$

Both sides are generally allowed to present witnesses at the trial ${ }^{212}$ and are required to furnish to each other a list of prospeotive witnesses. ${ }^{213}$ Should either party later desire to present any additional witnesses, an application must be made to the presiding officer. ${ }^{214}$ The Senate, on the application of managers or of the respondent or his counsel, is empowered to issue subpoenas in impeachment trials to coinpel the attendance of any witnesses ${ }^{215}$ or to procure papers. ${ }^{216}$ It is also the Senate, and not the presiding officer, that must rule on any motion for attachment of persons or papers. ${ }^{217}$ Where either party is not prepared to present testimony, the Senate, upon motion, may exercise discretion in delaying the trial to permit time for preparation. ${ }^{218}$

The presentation of testimony in the Senate trial is controlled by Senate, rather than by judicial, rules. Testimony presented in an impeachment trial need not be classified according to the particular article to which it applies. ${ }^{219}$ Witnesses are examined by one person on both sides, ${ }^{220}$ and any person, imcluding Senators, may be questioned as a witness. ${ }^{21}$ Although the inanagers and counsel for the respondent usually conduct all examinations of witnesses, Senators have on occasion presented questions by directing, through the presiding officer, ${ }^{222}$

they expected to prove.); id. $\S 2433$ (Evidence to be presented iu the trial was outlined and constitutional issues raised in the opening addresses of the Johnson trial.).

211. 3 HINDS' $\S \S 2091-93$. The Senate may by order extend the time allowed for arguments of motions and interlocutory questions. Id. See also SENATE IMPEAcHMENT RULE XXI, app. B infra.

212. See, e.g., 3 Hinds' \$ 2353 (Chase).

213. See, e.g., 6 CANNON's $\$ 484$ (Archbald); 3 Hinds' $\$ 2156$ (Belknap).

214. 6 CANNON'S $\$ 508$ (Archbald).

215. 3 Hinds' § 2158. See also Senate Impeachment Rule VI, app. B infra.

216. 3 Hinds' $\$$ 2038-39 (Blount).

217. Id. $\$ \S 2152-53$ (Swayne). See also 6 CannoN's $\S 523$ (The Senate in the Louderback impeachment ordered process to compel the attendance of a witness who had declined to respond to a subpoena.); $i d . \S 531$ (A witness who refused to testify was arrested and detained in custody.); 3 Hinds' $\$ 2160$ (The Senate in the Belknap case coinmanded a reluctant witness to produce certain papers in his possession.).

218. See, e.g., 3 Hinds' $\S 2353$ (The Senate in the Chase trial granted the managers' motion for a continuance because they were unprepared to present testimony.); id. § 2433 (The Senate in the Johnson trial granted the respondent's motion to continue to permit time for preparation of testimony for the defense.).

219. Id. $\S 2165$ (Chase).

220. Id. $\$ 2168$ (Chase). See also SENATE IMPEACHMENT RULE XVII, app. B infra.

221. See, e.g., 3 HINDS' $\$ 2164$ (Belknap); id. § 2309 (Blount); id. \$ 2336 (Pickering); id. $\$ 2378$ (Peck). See also SEnaTe IMPEACHMENT RULe XVII, app. B infra.

222. 3 Hinds' $\$ 2176$, See, e.g., 6 CANNoN's $\$ 522$ (Louderback); 3 Hinds' $\$ 2331$ 
questions in written form to witnesses, managers, or counsel. ${ }^{223}$ The respondent typically is permitted to appear in his own behalf ${ }^{224}$ and to respond at length to the charges against him.

\section{E. Evidentiary Rulings}

Since the Senate sits as both judge and jury, it is necessary for that body to adopt rules of evidence to govern the admissibility and relevance of evidentiary presentations in the course of its own trial. In soine trials, the Senate, following English precedent, has perfunctorily voted to adopt the rules of evidence currently in force in the courts. ${ }^{225}$ However, since the rules of evidence vary from jurisdiction to jurisdiction in the United States and since the rationale behind several evidentiary rules becomes inapposite in a Senate trial which operates without a jury that can be sequestered, it has been argued in other trials, often persuasively, that the regular rules of evidence should be relaxed. ${ }^{226}$

(Pickering). The managers or counsel for the respondent, however, may object to a witness' answering a question put by a Senator. See, e.g., id. $\$ \S 2182,2186,2187$. In such a case the Senate must rule on the objection. See, e.g., id. $\$ 2188$.

223. Cf. 3 Hinds' $\S \S 2180-81$ (Several Senators addressed verbal questions to the managers and to counsel for respondent, notwithstanding Senate Impeachment Rule XIX, app. B infra, which requires questions from one Senator to be in writing and to be put by the presiding officer.).

224. See, e.g., 6 CANNoN's $\$ 524$ (Louderback appeared at the trial and testified at length in his own behalf.).

225. 3 HINDS' $\$ 2218$. President Ford has recently signed into law the Federal Rules of Evidence. See Pub. L. No. 93-595 (Jan. 2, 1975), reprinted in 43 U.S.L.W. 137. Since these uniforn rules have been enacted, they are likely to be utilized in subsequent impeachment trials unless special rules of evidence adapted to the impeachinent process also are enacted. Historically, the Senate has remained faithful, broadly speaking, to the rules of evidence applicable in criminal trials before juries. However, Senate rules are such that this general position has been most often eaten up by exceptions in particular circumstances.

The Senate, after considering English precedent, ruled in the Peck trial that the strict rules of evidence in force in the courts should be applied. The ruling came after a lengthy debate and appeared to be the result of the Senate's efforts to assure a fair trial. Representative Storrs argued:

I confess I feel alarned to hear it gravely urged here that an impeachment is to be governed by other rules than the well-known and long-established rules of evidence. Rules of evidence are as much a part of the law of the land as any other part of it, and they constitute the security of every man. A more dangerous principle could not be broached, or a more alarming principle established than that in the trial of an impeachment, the ordmary rules of evidence are to be relaxed ... [such a practice] might easily lead to the most unjust and oppressive proceedings. 3 HINDS' $\$ 2218$, at 539.

226. In the Johnson trial, for example, it was suggested that the ordinary rules of evidence be relaxed:

Considering the character of this proceeding, that it is a trial of impeachment before the Senate of the Umited States, and not a proceeding by indictment in an inferior court;

Considering that Senators are, froin beginning to end, judges of law as well as fact, and that they are judges from whoin there is no appeal; 
Evidentiary rulings are made in the course of the trial itself in an ad hoc fashion. Evidentiary questions are "by long-established custom, submitted by the presiding officer to the Senate for decision";227 lowever, a Senator at his option may submit the question to the members of the Senate in the first instance. While evidentiary rulings of the presiding officer are said to be controlling, they can in practice be overruled by a majority vote of the Senate. For example, in the Johnson impeachment, although the Chief Justice of the United States, who presided over the trial, made preliminary rulings, every evidentiary question invariably was submitted to the Senate for final determimation. ${ }^{228}$ As a result, several of the Chief Justice's preliminary evidentiary rulings were overruled by majority vote. ${ }^{228}$ Thus, while the Senate has declined to liberalize the strict rules of evidence across the board, the proposition that the Senate may admit or exclude evidence by niajority vote has never been seriously questioned, ${ }^{230}$ and the Senate has often voted not to follow certain rules of evidence in particular cases. $^{231}$

In order to avoid the appearance of mampulating justice through ad hoc evidentiary rulings, it is suggested that a committee of the Senate be requested to examine the question of the appropriateness

Considering that the reasons for the exclusion of evidence on an ordinary trial where the judge responds to law and the jury to the fact are not applicable to such a proceeding;

Therefore, . . . it is deemed advisable that all evidence offered on either side not trivial or obviously irrelevant in nature shall be received without objection. 3 Hinds' $\$ 2219$, at 540 .

A strong argument can be made for modifying in a Senate impeachment trial those exclusionary rules of evidence designed primarily to protect a jury in a criminal proceeding. Similarly, in a criminal trial without a jury, evidentiary rules are modified substantially because the court presumably is able to determine the appropriate weight to be given all the evidence without being swayed unduly by questionable evidence. In a Senate trial, the Senators sit as deciders of fact and law, judge and jury; thus it need not follow that the Senate should be bound by rules designed to protect only its jury functions. Moreover, the political nature of the impeachment process is such, especially in presidential impeachment, that much of the evidence upon which conviction or exoneration is based is by then in the public domam. There is simply no way to sequester the Senate. If defense counsel is fairly to have an opportunity to rebut formally in the course of a Senate trial evidence of wrongdoing, whether hearsay or otherwise, all serious issues should be presented within that forum.

227. 6 CANNON's $\$ 491$, at 678 .

228. 3 Hnnds' $\S 2222$. See also 6 CANnon's $\S 491$, at 678 (The President pro tempore referred to the Johnson trial for the precedent that the Chief Justice's rulings were invariably put to a Senate vote.).

229. 3 Hunds' $\$ 2222$.

230. Id. $\S 2167$ (Belknap).

231. See, e.g., 6 CANNoN's $\$ 510$ (The Senate by its own order disregarded an established rule of evidence in the Archbald case.). 
of present evidentiary rules governing an impeachment trial at a time when minds are free from the adversarial influences generated in the anticipation or conduct of a particular trial. General guidelines can be adopted, and principles for adapting the jury-oriented evidentiary rules to Senate use can be delineated.

\section{F. Final Arguments and Voting}

Final arguments on the merits in an impeachment trial are made by two persons on each side, unless modified by prior application.232 Following final arguments, the final judgment is put to the Senate. ${ }^{233}$ Consistent with the Senate rule allowing only yea and nay voting in impeachment proceedings, ${ }^{234}$ the Senate has declined to permit any expression as to whether the offenses charged constituted high crimes and misdemeanors. ${ }^{235}$ The consequence of this rule is that a negative vote could mean either that a Senator considered (1) that the offense embodied in the article of impeachment did not constitute a "high crime and misdemeanor," whether or not committed by the defendant, or (2) that the defendant was not guilty of the commission of the offense charged, whether or not it constituted an impeachable offense. However, in the interest of precedential clarity and due to the dual role of the Senate as both judge and jury, it is urged that the form of the final question be modified in order to allow each Senator to respond

232. See 3 HINDs' $\$ 2132$ (The managers and counsel for respondent in the Johnson trial successfully objected to the rule limiting the number entitled to make final arguments on each side.). See also Senate ImPEACHMENT Rule XXII, app. B infra.

233. The articles are generally read successively, with the question of guilty or not guilty being presented in open session to each Senator for separate consideration.

234. See, e.g., 3 Hinds' $\$ 2363$ (Chase). The form of the final question, following the Chase precedent, has been:

Mr. how say you; is the respondent

guilty or not guilty of a high crime or misdemeanor, as charged in the article of impeachment. Id.

235. See, e.g., id. $\$ 2339$ (Pickering). See also 6 CANNoN's $\$ 457$, containing a monograph by Wrisley Brown, of counsel on behalf of the managers in the Archbald impeachment, which was printed as a public document following Archbald's conviction, and which reads as follows:

The impeachments that have failed of conviction are of little value as precedents because of their close intermixture of fact and law, which makes it practically impossible to determine whether the evidence was considered insufficient to support the allegation of the articles, or whether the acts alleged were 'adjudged insufficient in law to constitutue impeachable offenses' Neither of the successful inpeachments prior to the case of Judge Archbald was defended, and they are not entitled to great weight as authorities. . . . But, it will be observed, none of the articles exhibited against Judge Archbald charged an indictable offense, or even a violation of positive law. ... Therefore, the judgment of the Senate in this case has forever removed from the domain of controversy the proposition that judges are only impeachable for the cominission of crimes or inisdemeanors against the laws of general application. Id. at 637-38. 
on both the legal and factual elements of the final verdict. ${ }^{236}$

The issue of the applicablility of the doctrine of disqualification based upon personal interest, as applied to a Senator voting on impeachment, has been raised but not acted upon. ${ }^{237}$ The President pro tempore of the Senate during the Johnson trial, for example, participated despite the fact that a conviction would have made him President. $^{238}$ Also, a Senator related to Johnson was not challenged when he voted on the final impeachment question. ${ }^{239}$

\section{G. Judgment}

Under the Constitution, if an impeachment is not sustamed by a two-thirds vote on any article, the accused is acquitted. ${ }^{240}$ Where conviction is accomplished, the Senate inust decree the defendant's removal from office and may disqualify him from loolding any public office in the future. ${ }^{241}$ Debate has occurred in the Senate as to whether or not the Constitution requires both removal and disqualification upon conviction. In both the Archbald and the Humphreys cases, the President pro tempore ruled that the two questions were separate and divisible propositions, the former bemg mandatory and the latter discretionary. ${ }^{242}$

\section{Raising the Defense of Executive Privilege}

Why, what mockery it would be for the Constitution of the United States to say that the House should have the power of impeachment extending

236. The filing of individual opinions to be published in the Senate records presently provides the only indication, other than the actual vote, as to whether the offense charged constituted a "high crime and misdemeanor" and whether the accused was guilty of its commission.

237. See, e.g., 3 HnNDs' § 2061 (Johnson).

238. Id.

239. Id. It should also be noted that in the Pickering trial a Senator, who had previously voted for impeachment as a member of the House, was challenged but allowed to vote. Id. $\$ 2327$. Senators on the other hand, have often been excused from voting for various reasons. See, e.g., 6 CanNon's $\$ 516$ (Senators in the Louderback case were excused for various reasons from voting on all or part of the impeachment articles.); 3 HINDs' $\$ 2114$ (A Senator who had not heard the evidence was excused from voting on the question of guilt in the Swayne trial.); id. $\$ 2383$ (One Senator in the Peck trial was excused from voting on the judgment because he had appeared as a witness and another Senator was excused from voting because he had taken his seat after part of the testimony had been presented.); id. $\$ 2396$ (Various Senators were excused froin voting in the Humphreys case.).

240. U.S. ConST. art. I, § 3, cl. 6.

241. Id. cl. 7.

242. See 6 CANNon's $\S 512$, at 706 (Archbald); 3 Hinds' $\$ 2397$, at 820 (Humphreys). 
even to the President of the United States himself, and yet to say that the House had not the power to obtain the evidence and proofs on which their impeachment was based. It appeared to him [John Adams] equivalent to a self-evident principle, that the power of impeachment gives to the House necessarily the power to call for persons and papers.

John Quincy Adams ${ }^{243}$

Congressional power to obtain information concerning an official's conduct is critical to every stage of any impeachment process. Consequently, a claim of executive privilege to withhold information from an impeachment investigatory committee at any stage of the process would threaten to einasculate the power granted Congress by the Constitution to impeach any federal official, especially the President. ${ }^{2+4}$ Thus, while executive privilege possesses a certain legitimacy in spite of dubious parentage, there exists a strong presumption against any use of executive privilege to obstruct an impeachment investigation.

The constitutional status of executive privilege has been the subject of much recent debate. ${ }^{245}$ Historically, the doctrine was invoked rarely and in narrow circumstances. ${ }^{246}$ During the Eisenhower administration it was seriously contended that the President has unlimited discretion to withhold any information froin Congress or the courts, ${ }^{247}$ but

243. Cong. Globe, 27th Cong., 2d Sess. 580 (1842).

244. "The House of Representatives shall . . . have the sole Power of Impeachment." U.S. CoNst. art. I, $\S 2$, cl. 5. "The Senate shall have the sole Power to try all Impeachments." Id. art. I, $\$ 3$, cl. 6. Congress, the coordinate political branch, and not its least dangerous sister, is ultimately the only natural balance to the executive. $C f$. Bickel, Should Rodino Go to Court?, The New Republic, June 8, 1974, at 11.

245. See, e.g., Berger, Executive Privilege v. Congressional Inquiry, 12 U.C.L.A.L. REv. 1287 (1965); Committee on Civil Rights of the New York City Bar, Executive Privilege: Analysis and Recommendations for Congressional Legislation, 29 RECORD OF N.Y.C.B.A. 177 (1974); Dorsen \& Shattuck, Executive Privilege, The Congress and the Courts, 35 OHIo Sr. L.J. 1 (1974); Ervin, Controlling "Executive Privilege," 20 LoyolA L. REv. 11 (1974); Harden, Executive Privilege in the Federal Courts, 71 YALE L.J. 879 (1962); Henkin, The Right to Know and the Duty to Withhold: The Case of the Pentagon Papers, 120 U. PA. L. Rev. 271 (1971); Kramer \& Marcuse, Executive Privilege-A Study of the Period 1953-1960, 29 GEo. WASH. L. REv. 623, 827 (1961); Kutner, Executive Privilege . . . Growth of Power over a Declining Congress, 20 Loyola L. REv. 33 (1974).

246. EXeCUTIVe PRTVILEge 163-208.

247. The House Foreign Operations and Government Information Subcominittee reported in March 1973 that since 1952 executive privilege had been invoked 49 timesmore than twice the number of all prior claims. The Present Limits of "Executive Privilege," Cong. Rec. 2243-46 (daily ed. Mar. 28, 1973). After that report, the Nixon Administration asserted executive privilege at least four additional times including an assertion against complying with a subpoena duces tecum directed by the Senate Select Cornmittee on Presidential Campaign Activities, a subpoena from Special Prosecntor Archibald Cox, and later from Special Prosecutor Jaworski, and finally a subpoena issued by the House Judiciary Committee incident to its impeachment inquiry. 
the validity of that claim of absolute executive privilege has been vigorously contested by both the courts ${ }^{248}$ and Congress. ${ }^{249}$ In view of the firm responses of the Supreme Court and Congress denying the President's claim of an absolute privilege to withhold information, it is appropriate to examine the development of the doctrine of executive privilege and its limitations.

Under the common law of English parliamentary government, in whicl the Prime Minister must be elected as a member of Parliament, there exists ample precedent for parliamentary investigation of executive conduct, both for purposes of initiating legislation and undertaking inipeachnent. ${ }^{200}$ In America, lowever, the separation of powers doctrine, which makes the Executive imdependent of direct legislative control, has given birth to a limited doctrine of executive privilege. The Executive has frequently withheld information from the courts, the Congress, and the people by asserting the principle of separation of powers directly, the need for confidentiality, or rights granted by statute. Nevertheless, none of these bases can support an absolute claim to executive privilege, especially with respect to a congressional inlpeachment investigation.

\section{A. Executive Privilege Based on Separation of Powers}

The claim of an absolute executive privilege based on separation of powers ${ }^{251}$ was rejected judicially in Nixon $v$. Sirica ${ }^{252}$ and United States $v$. Nixon, ${ }^{253}$ and it was repudiated congressionally incident to the Nixon inipeachment proceeding. ${ }^{254}$ These judicial and congressional pronouncements imply that the doctrine of executive privilege is predominantly extra-constitutional. In United States $v$. Nixon, ${ }^{255}$ the

248. The Supreme Court in United States v. Nixon, 94 S. Ct. 3090 (1974), rejected the Executive's claim to privilege based upon separation of powers and the need for confidentiality between the President and his closest aides. See also Nixon v. Sirica, 487 F.2d 700 (D.C. Cir. 1973).

249. The House Judiciary Committee repudiated President Nixon's claim of privilege to withhold information from an impeachment investigation by voting the articles of impeachment contained in appendix $C$ infra.

250. EXeCUTIVE Privilege 15-48.

251. See notes 247 supra \& 263 infra and accompanying texts.

252. 487 F.2d 700 (D.C. Cir. 1973).

253. 94 S. Ct. 3090 (1974).

254. See note 249 supra. Although a minority of the Committee argued that its subpoena should be taken to the courts for enforcement, counsel for the majority of the Committee concluded that congressional power to inquire incident to impeachment has an even more well-established constitutional base than judicial power to compel presidential disclosure. 32 Cong. Q. 2013-14 (1974).

255. The case arose when the President filed a motion to quash a trial subpoena duces tecum directed to the President for presidential materials and a motion to expunge 
President's counsel raised three poimts before the Supreme Court to support his assertion that executive privilege is a proper basis for disregarding a subpoena of a federal district court. All three were essentially separation of powers arguments: first, that "[i]nherent in the executive power vested in the President under anticle II of the Constitution is executive privilege, generally recognized as a derivative of the separation of powers"; ${ }^{256}$ second, that since the courts have no jurisdiction over impeachment-related matters, the use of a court subpoena to force the production of presidential documents while an impeachment is in process would accomplish indirectly what the Constitution clearly prohibits;; ${ }^{257}$ and third, that "the common law and its einbodiment of the concept of confidentiality as a prerequisite to the effective administration of government"258 requires that the privilege be recognized. The Count, however, unceremoniously rejected each of these arguments, ${ }^{259}$ while conceding that presidential communications are "presumptively privileged," the Court held that the "generalized assertion of privilege must yield to the deinonstrated, specific need for evidence in a pending criminal trial." 260

Certainly, this denial of a President's assertion of privilege against a judicial subpoena recognized general limits on the doctrine of executive privilege, at least to the extent that an assertion of privilege may be countered by the competing interests of the other branches of

any finding of the grand jury that he was an unindicted co-conspirator in the criminal proceedings commonly known as Watergate. $94 \mathrm{~S}$. Ct. at 3096, citing United States v. Mitchell, No. 110 (D.D.C. Apr. 30, 1974). The district court held that under Nixon v. Sirica, 487 F.2d 700 (D.C. Cir. 1973), the court had the authority to rule on the scope and applicability of executive privilege and further that its jurisdiction was not affected by the intra-executive nature of the dispute. $94 \mathrm{~S}$. Ct. at 3103 . It then found that the Special Prosecutor had demonstrated a "compelling need" which under Sirica was necessary to overcome the presumptively privileged nature of presidential documents and papers. Id. at 3105.

256. Brief for Respondent at 17 \& 49, United States v. Nixon, 94 S. Ct. 3090 (1974).

257. Id. at 15 .

258. Id. at 50 .

259. The first: "[N]either the doctrine of separation of powers, nor the ueed for confidentiality of high level communications, without more, can sustain an absolute, unqualified presidential privilege of immunity from judicial process under all circumstances." $94 \mathrm{~S}$. Ct. at 3106.

The second: "[T]he legitimate needs of the judicial process may outweigh presidential privilege ...." Id. at 3107 .

And the third:

Absent a claim of need to protect military, diplonnatic or sensitive national security secrets, we find it difficult to accept the argument that even the very important interest in confidentiality of presidential communications is significantly diminished by production of such nuaterial for in camera inspection with all the protection that a district court will be obliged to provide. Id.

260. Id. at 3110 . 
government exercising their respectively authorized functions. Thus, it would seem that, when the privilege is asserted against an impeachment inquiry, the circumstances under which executive privilege would justify the President's refusal to divulge information are indeed limited, if not wholly hypothetical. Stated another way, a presuinption of almost insurmountable proportions exists against the exercise of executive privilege when it is used to avoid supplying persons or papers requested by the House upon its constitutionally based power to impeach. This conclusion is consistent with the earher treatment of claims of executive privilege in other contexts based upon the separation of powers.

The earlier cases of executive privilege have been read by its proponents to support the invocation of an absolute privilege; however, a more careful analysis shows that these precedents actually refute such a proposition. Frequently, the first precedent cited is Washington's refusal in $\mathbf{1 7 9 6}$ to submit requested materials concerning the Jay treaty negotiations to the House. This incident cannot be interpreted to support an argunent for absolute executive privilege based upon the doctrine of separation of powers, since Washington had already submitted the requested materials to the Senate. Rather than asserting any executive privilege, Washington refused to disclose to the House the instructions that he had given to his ministers on the grounds that the treaty-inaking power was exclusively vested in the President and the Senate. He therefore contended that the House request was not incident to one of its assigned responsibilities: "[T]he inspection of the papers asked for can [not] be relative to any purpose under the cognizance of the House . . . except that of impeachment; which the resolution has not expressed."201 Washington's refusal was couched carefully in narrow terms; rather than rejecting the power of Congress to inquire into executive conduct when such an investigation is conducted incident to a legitimate congressional responsibility such as impeachment, Washington explicitly recognized that right. ${ }^{262}$

261. 5 ANnals of Cong. 759-60 (1796) [1789-1824] (emphasis added).

262. Washington declared his intent not to "withhold any information ... which could be required of him by either House of Congress as a right." Id. at 760 . Nevertheless, his refusal was not wholly acquiesced to by the House of Representatives. Members insisted on clarifying their right to demand information from the Executive:

The right of calling for papers was sanctioned . . . by the uniform and undeniable practice of the House ever since the organization of the Governinent .... [T] he House had the fullest right to the possession of any papers in the Executive department .... [T] his was the first time it had ever been controverted. Id. at 601.

Accordingly, a member of the House asserted that if information "came within [the House's] powers, [it] would have a right to the papers" and the House would "demand them, and insist on the demand." Id. at 458. 
President Andrew Jackson in 1833 was the first President to assert the doctrine of executive privilege based upon the separation of powers. He refused to answer a Senate request for papers which contained the President's policy statements to his cabinet concerning the removal of public funds from the Bank of the United States (perhaps in anticipation of or to hasten its failure). He explained to Congress:

The Executive is a coordinate and independent branch of the Government equally with the Senate, and I have yet to learn under what constitutional authority that branch of the Legislature has a right to require of me an account of any communication . . . made to the heads of Departments acting as a Cabinet council. ... .

I am constrained, therefore, by a proper sense of my own self respect and of the rights secured by the Constitution to the executive branch of the Government to decline a compliance with your request. ${ }^{263}$

In 1835 , Jackson reasserted this argument in refusing to supply the Senate with a copy of charges that had been brought against a recently dismissed surveyor-general: "This is another of those calls for information made upon ine by the Senate which have, in iny judgment, either related to the subjects exclusively belonging to the executive departinent or otherwise encroached on the constitutional powers of the Executive."264 In asserting a claim of privilege based on separation of powers, however, Jackson distinguished between congressional investigation of purely executive affairs and congressional inquiry incident to a constitutionally inandated congressional duty:

[C]ases may occur in the course of its legislative or executive proceedings in which it may be indispensable to the proper exercise of its powers that it should inquire or decide upon the conduct of the President or other public officers, and in every case its constitutional right to do so is cheerfully conceded. ${ }^{265}$

Thus, while Jackson clearly propounded a separation of powers argument in defense of a privilege to withhold information, the assertion was narrow rather than absolute and caimot serve as a precedent for a refusal to provide information related to an impeachment inquiry. This sane restrictive understanding of the privilege was adhered to by President Tyler. ${ }^{268}$ This distinction, along with an acknowledged re-

263. 3 J. Richardson, Messages and Papers of the Presidents 36 (1897). Rather than acquiescing to the President's conduct, the Senate censured the President. See note 408 infra.

264 Id. at 132.

265. Executive Privilege 182.

266. See $4 \mathrm{~J}$. RICHARDSON, supra note 263 , at 105-06.

While I shall ever evince the greatest readiness to communicate to the House 
servation for inquiry pursuant to an impeachment investigation, was drawn by Buchanan in 1860: "Except in [the] single case [of impeachinent], the Constitution has invested the House of Representatives with no power, no jurisdiction, no supremacy whatever over the President. In all other respects he is quite as independent of thein as they are of him."207 The same thesis was asserted by Grant in 1876 in refusing to comply with a request for information when the Democratic House appeared bent on publicly embarrassing the administration:

I fail, however, to find in the Constitution of the United States the authority given to the House of Representatives . . . to require of the Executive, an independent branch of the Government, coordinate with the Senate and the House of Representatives, an account of his discharge of his appropriate and purely executive offices, acts, and duties, either as to when, where, or how performed.

What the House of Representatives may require as a right in its demand upon the Executive for information is limited to what is necessary for the proper discharge of its powers of legislation or of impeachment. ${ }^{208}$

Until the present era, this interpretation of executive privilege and the inpeachment investigatory powers of Congress had gone unchallenged. Recently, however, the claim of privilege has been debated at length in the context of contemporary political controversies. ${ }^{209}$ This has led to the advancement of the further, more sweeping claim that all commumications between employees in the executive branch must be per se immune from the investigations of Congress in order that

of Representatives all proper information which the House shall deem necessary to a due discharge of its constitutional obligations and functions, yet it becomes me, in defense of the Constitution and laws of the United States, to protect the executive department from all encroachment on its powers, rights, and dnties. In my judgment a compliance with the resolution which has been transmitted to me would be a surrender of duties and powers which the Constitution has conferred exclusively on the Executive .... Id.

267. 5 id. at 615 .

268. 7 id. at 362 (emphasis added).

269. In one such debate Congressman Richard Nixon, a member of the House Un-American Activities Committee, responded to President Truman's refusal to release information pertaining to the loyalty of a prominent government scientist:

The point has been made that the President of the United States has issued an order that none of this information can be released to the Congress and that therefore the Congress has no right to question the judgment of the President in making that decision.

I say that that proposition cannot stand from a constitutional standpoint or on the basis of the merits for this very good reason. That would mean that the President could have arbitrarily issued an Executive order in the Myers case, the Teapot Dome case, or any other case denying the Congress of the United States information it needed to conduct an investigation of the executive department and the Congress would have no right to question his decision.

Any such order of the President can be questioned bv the Congress as to whether or not that order is justified on the merits. 94 CoNG. REc. 4783 (1948). 
federal employees can "be completely candid in advising with each other."270 Nevertheless, the logic and internal consistency of this position has been sharply criticized. ${ }^{271}$ It is difficult to imagine a need for candor between two members of the executive branch which is so profound as to impede Congress' ability to utilize the constitutional processes to protect against the abuse of public office.

Neither the historical precedents nor the day-to-day pressures upon the executive branch can support a claim of absolute immumity for presidential documents or testimony based upon the doctrine of separation of powers, when such materials are sought to be withheld from Congress acting pursuant to the impeachment powers. Therefore, while the most respectable claim to executive privilege can probably be based upon the concept of separation of powers, that claim surely founders in the impeachment context since impeachment was conceived as an "exception to [the] principle"272 of separation of powers.

\section{B. Withholding Information When the Public Interest Requires Executive Secrecy}

The court in Nixon $v$. Sirica ${ }^{273}$ characterized the predominant basis of executive privilege as one of public policy, ${ }^{274}$ not constitutional mandate, and this view is in accordance with the weight of precedent. Thus, the privilege of secrecy is not impregnable and may be overridden by a superior public policy interest, and it will be overridden wherever a competing constitutional imterest, such as impeachment, is present.

From the earliest days of the Republic, the doctrime of executive privilege has been associated with a consideration of public protection rather than constitutional prerogative. In 1792, for example, when Washington was President, the House of Representatives requested military papers pentaining to Major General St. Clair's unsuccessful expedition against the Indians. Since all of the papers were given to Congress, the tenuous precedential value of this transaction rests on Jefferson's notes of a cabinet ineeting discussing the circumstances under which nondisclosure would be proper:

270. Executive Prinirege 234. This argument appears in an executive directive reprinted in 100 CONG. REC. 6621 (1954). See generally EXECUTIVE PRIVILEgE 234-35.

271. Executtve Privilege 164. See also United States v. Nixon, 94 S. Ct. 3090 (1974).

272. 1 Annals of Cong., supra note 9.

273. 487 F.2d 700, 713, 716 (D.C. Cir. 1973).

274. Public policy, for these purposes, will protect national security and a necessary degree of confidentiality and candor in presidential conversation. 
We had all considered and were of one mind. 1. that the house was an inquest, and therefore might institute inquiries. 2. that they might call for papers generally. 3. that the Executive ought to communicate such papers as the public good would permit, and ought to refuse those the disclosure of which would imjure the public.

It was agreed in this case that there was not a paper which might not be properly produced. . . . .75

This illustrates the point that the executive privilege of secrecy can only be asserted upon some showing of injury to the public good. Traditionally, the courts and Congress have respectfully prefaced requests for presidential information with the declaration that such materials are "presuinptively privileged," and they have invited the withholding by the Executive of any inaterials whenever their release would not be in the public interest. ${ }^{276}$ The need for sustaining that privilege of presidential confidentiality, lowever, has only been respected where some explicit public good is shown to be jeopardized by disclosure. In the Burr trial, for example, the court subpoenaed certain letters in Jefferson's control which Burr deeined essential to his defense and required that they be produced unless it could be shown that the letters contained inatters which, in the public interest or security, ought not to be disclosed:

There is certainly nothing before the Court, which shews, that the letter in question contains any matter, the disclosure of which would endanger the public safety. If it does contain any matter which it would be imprudent to disclose, which it is not the wish of the Executive to disclose, such matter, if it be not immediately and essentially applicable to the point, will of course, be suppressed. ${ }^{277}$

Consequently, the burden of proof was placed upon the Executive seeking to raise a defense of immunity based upon a need for secrecy or confidentiality. Accordingly, Jefferson responded to the subpoena, ${ }^{278}$ reserving only the right to withhold inaterials which were im-

275. Berger has argued that Jefferson misinterpreted English precedent in suggesting that the Executive had authority in certain circumstauces to refuse to provide presidential papers. EXECUTIVE PRIVILEGE 169-70.

276. The House request, for example, for materials involving the Jay Treaty instructions excepted "such of said papers as any existing negotiation may render improper to be disclosed." 5 AnNals of Cong., supra note 261, at 759. The House request for presidential papers bearing on the Burr conspiracy also excepted such materials as Jefferson "may deem the public welfare to require not to be disclosed." Executive Privilege 179.

277. 1 T. Carpenter, The Trial of Colonel Aaron Burr 133 (1807), cited in Berger The President, Congress, and the Courts, 83 YALE L.J. 1111, 1114 (1974).

278. Berger cited references to commentators who have stated that Jefferson refused to respond to Chief Justice Marsliall's subpoena. EXecutrve Privilege 1112. 
material to the action $s u b$ judice, by transmitting all evidence requested, "excepting such parts thereof as are, in my opimion, not material for the purposes of justice, for the defense of the accused, or pertinent to the issue .... The accuracy of this opimion, I am willing to refer to the judgment of the Court, by submitting the original letter for its inspection."279 The Burr trial provides precedent for judicial power to subpoena presidential papers subject to the limitation that materials surveyed by the court which are irrelevant to the case under adjudication may properly be withheld and suppressed on a claim of privilege. The onus of proof justifying any broader claim of confidentiality, however, clearly falls upon the Executive.

The courts in both Nixon $v$. Sirica and United States $v$. Nixon followed the Burr precedent by requiring that the President provide materials "essential to the justice of the [pending criminal] case." The court in Nixon $v$. Sirica recognized that while it ought to "show respect for the President in weighing those reasons [for nondisclosure] ... the ultimate decision reinained with the court."281 In United States $v$. Nixon, the Supreme Court followed the Burr case in holding that, while presidential documents were "presumptively privileged," the claim "cannot prevail over the fundamental deinands of due process of law in the fair administration of criminal justice. The generalized assertion of privilege must yield to the demonstrated, specific need for evidence in a pending trial." ${ }^{282}$ Although the Nixon cases arose out of a dispute exclusively within the executive branch, the logic of these decisions is equally persuasive when applied to congressional requests. Where the President claims a privilege of secrecy to withhold material information from either the courts or Congress, functioning within their respectively mandated spheres, the President's claim must be made responsibly and subject to prima facie review. In the case of pending criminal trials, the courts have provided the procedure of in camera inspection of presidential papers as a means of reviewing such a claim of privilege, but in the case of congressional inquiries, the procedure is presently unclear. Since the public interest involved in congressional inquiries, particularly impeachment imquiries, is at least as great as the interests involved in the promotion of criminal justice, Congress too should establish a similar reviewing protocol with selected leaders ac-

279. Id. at 1116 (emphasis added), quoting $3 \mathrm{~T}$. CARPENTER, supra note 277, at 30.

280. United States v. Nixon, 94 S. Ct. 3090, 3110 (1974), citing United States

v. Burr, 25 F. Cas. 187, 192 (No. 14,694) (C.C.D. Va. 1807).

281. 487 F.2d 700, 710 (D.C. Cir. 1973).

282. $94 \mathrm{~S}$. Ct. at 3110. 
complishing an in camera inspection to review claims of confidentiality in opposition to congressional requests for persons and papers.

\section{Withholding Information on the Basis of a Statutory Privilege}

Statutes permitting confidentiality have been invoked in support of an executive claim of privilege under limited circumstances but never in opposition to the impeachment process. The purpose of the Freedoin of Information $\mathrm{Act}^{283}$ is to make available to "any person" upon request governmental records not falling within certain specified exceptions, ${ }^{284}$ and to a certain extent, the Act attempts to codify the doctrime of executive privilege. ${ }^{285}$ But the Act explicitly states: "This section is not authority to withhold information from Congress." Furthermore, since the courts have generally declined to abdicate control over evidence to the caprice of executive officers, ${ }^{287}$ and since it caumot be concluded that Congress has relinquished any of its extraordimary power to impeach the President simply by having recognized the doctrine of executive privilege in general information-access legislation, one nust conclude that a claim of privilege asserted under the Freedoun of Information Act or any other such statute is not applicable

283. 5 U.S.C. $\$ 552(1970)$.

284. EPA v. Mink 410 U.S. 73 (1973). The Supreme Court held that where government documents are clearly classified under the statute even an in camera proceeding was improper. Id. at 84. For a discussion of Mink, see Comment, Developments Under the Freedom of Information Act-1973, 1974 DuKE L.J. 251, 252-57.

285. Committee on Civil Rights of the New York City Bar, supra note 245, at 182.

Prior to the passage of the Freedom of Information Act, cases invoking the privilege were often based upon R.S. 161 (5 U.S.C. \$ 22, now 5 U.S.C. \$ 301), which provided that department heads were authorized to prescribe regulations, not inconsistent with law, for the custody and use of governmental records. Id. at $205 \mathrm{n} .19$.

Sec, c.g., Touhy v. Ragen, 340 U.S. 462 (1951); Boske v. Commingore, 177 U.S. 459 (1900); Hubbard v. Southern Ry., 179 F. Supp. 244 (M.D. Ga. 1959).

286. 5 U.S.C. $\S 552(\mathrm{c})(1970)$. The Act exempts nine types of information from its coverage. The doctrine of executive privilege is apparently codified in exemptions (1), (5) and (7). Exemption (1) includes materials "specifically required by Executive order to be kept secret in the interest of the national defense or foreign policy." Exemption (5) includes "inter-agency or intra-agency memorandums or letters which would not be available by law to a party other than an agency in litigation with the agency." This exemption relates to law enforcement and civil and criminal discovery. Exemption (7) is essentially the same as (5) differing only in that (5) covers cases in which the government is a party and (7) extends to all contexts involving the discovery of law enforcement investigatory files. See generally Comment, supra note 284 , at 252-59, 274-80, 284-88.

287. Sec, e.g., Tennessean Newspapers Inc. v. FHA, 464 F.2d 657 (6th Cir. 1972); Getman v. NLRB, 450 F.2d 670 (D.C. Cir. 1971); Wellford v. Harden, 444 F.2d 21 (4th Cir. 1971). But see Consumers Union of United States v. Veterans Administration, 301 F. Supp. 796 (S.D.N.Y. 1969), dismissed as moot, 436 F.2d 1363 (2d Cir. 1971). 
to congressional investigations; especially where the investigation is incident to an impeachment proceeding.

In sum, the assertion that the Executive has an absolute discretion to withhold materials froin both the Congress and the courts on any basis has been shattered by both the Supreme Court in United States v. Nixon ${ }^{288}$ and the Judiciary Committee of Congress by its vote on the third article of impeachment. ${ }^{289}$ This rejection of executive privilege, taken together with the formal congressional reaction to executive (undeclared) war, ${ }^{290}$ to executive acts approaching the 1nonarchical tradition of being above the law, ${ }^{201}$ to executive corruption of government agencies, ${ }^{292}$ and to campaign financing abuses, ${ }^{293}$ closes an era of unchallenged presidential ascendancy.

\section{EXCLUDING EVIDENCE ON OTHER CONSTITUTIONAL OR EVIDENTIARY GROUNDS}

Just as a claim of executive privilege nnay not be extended to bar congressional investigation of executive wrongdoing, so many other procedural and civil privileges take on a different legal meaning within the context of an impeachment trial. Confusion of the political role of the impeachment trial with the juridical role of a trial by jury imight suggest the need to transpose the prevailing concepts of procedural or substantive due process froin the judicial setting to the impeachment process. Due process, however, is not simply the equivalent of being fair; such a simplistic transposition would not be proper. Nevertheless, such concepts as due process and evidentiary privileges may in the future play an important role in establishing the evidence necessary for impeachment and removal froin office, especially as concrete evidence like tape recordings of incriminating conversations may not be available for future impeachment proceedings. No doubt the fifth amendment rights, the fourth amendinent protections, and the evidentiary privileges afforded an accused or testifying witnesses may become a debated issue in future impeachment proceedings.

288. 94 S. Ct. 3090 (1974).

289. See ARTiCLES of IMPEACHMENT art. III, app. C infra.

290. In order to limit the Executive's heretofore untrammeled power to carry on undeclared war, Congress has passed the War Powers Act. Act of Nov. 8, 1973, 87 Stat. 555 (codified at 50 U.S.C.A. $\$ \$ 1541-48$ (Supp. 1974)).

291. See ARTICles of IMPEACHMENT art. I, app. C infra.

292. See ARTiCles of IMPEACHMENT art. II, app. C infra.

293. In an attempt to amehorate presidential campaign financing abuses Congress recently has enacted the Federal Election Campaign Act Amendments of 1974. Act of Oct. 15, 1974, Pub. L. No. 93-443. 
The applicability of concepts of due process is immediately suggested by the mere prospect of the government's taking valuable personal rights, offices, and employment from the citizens who hold them. ${ }^{204}$ The fifth amendment would appear to protect public officers from any taking of office or injury to reputation or future opportunity, except upon the condition that it is accomplished according to the requirements of due process, ${ }^{205}$ simce the Constitution would seen to authorize dismissal from office only upon a showing of good cause. ${ }^{236}$ However, a President who attempts to invoke the due process clause of the fifth amendment to impose upon the Congress a specific standard of justice to be observed in the conduct of the impeachment proceeding may fail for the following reasons. First, the Bill of Rights was adopted to protect private citizens fron 1 encroachments upon their liberties by powerful federal officers; never does there appear any imdication in the writings of Jefferson or those who advocated the ratification of the fifth amendment that the due process clause should also regulate the interrelationships between those federal officers or, indeed, constitute an ultimate principle superimposed upon the principle of separation of powers otherwise defined in the Constitution. Moreover, certain presidential claims, such as the assertion of executive privilege, rest exclusively upon the assumption that the individual raising then does so as President and not in his capacity as a private citizen. Thus, in order to invoke the personal protections of the fiftl amendment, the President must take a position that would be inconsistent with any protections that he claimed because of the status of his office. Second, there is no simple concept of due process per se. Rather, the standard

294. See Bishop v. Wood, 377 F. Supp. 497, 501 (W.D.N.C. 1973); cf. Perry v. Sindermann, 408 U.S. 593 (1972); Bell v. Burson, 402 U.S. 535 (1971).

295. See Board of Regents of State Colleges v. Roth, 408 U.S. 564 (1972); Fuentes v. Shevin, 407 U.S. 67 (1972); Goldberg v. Kelly, 397 U.S. 254 (1970); Cafeteria Local 473 v. McElroy, 367 U.S. 886 (1961); Joint Anti-Fascist Refugee Comm. v. McGrath, 341 U.S. 123, 185 (1951).

296. By enumerating specific crimes and circumstances against which impeachment may ensue, the Constitution would appear to incorporate a "good cause" requirement for dismissal. Moreover, the phrase "high Crimes or Misdemeanors" does not nullify that requirement through any vagueness, as the following historical analysis demonstrates. The English impeachment of Warren Hastings for high crimes and misdemeanors was voted shortly before the beginning of the Constitutional Convention, and his trial was referred to in the debates. See R. BERGER 3 n.15, 94; 2 RECORDS $550 ; 1$ J. STORY $\S 799$, at 583 . Story asserts that "what are and what are not high crimes and misdeineanors is to be ascertained by a recurrence to English law." In the Swayne trial, it was argued that the phrase "high Crimes and Misdeineanors" is a "term of art," of fixed meaning in English parliamentary law and transplanted to the Constitution in unchangeable significance. See 3 HiNDs' $\$ 2009$; Firmage, note 14 supra, at 682. 
of due process which is required by any given situation is determined independently by reference to the nature of the right which is sought to be protected. ${ }^{297}$ Just as the procedure which is adequate for the vindication of welfare rights is not the same as that which is required to prove a felony charge, ${ }^{208}$ so one cannot import into and appropriate for use in the impeachment process any given standard of due process which happens to attach to another given substantive right in our society. The meaning which due process therefore will have in the impeachment context must be founded upon a wide-ranging analysis of the total impeachment process; it inust not merely reflect the interests of any one officer who is seeking to retain his office. Third, the impeachment process is itself a well-defined political proceeding which operates only upon the observance of its established rules and constraints. These provisions provide ample procedural protection, affording an accused the rights of notice and hearing which characterize the essence of due process. ${ }^{299}$ No taking of office occurs before this elaborate procedure has been carried out, and even after it has been carried out the removed officer has additional, though limited opportunities to clear his name and reputation in subsequent actions in the courts. $^{300}$ Finally, since the total scheme which is embedded in the Constitution anticulates both the rights of office and the manner in which a person's tenure of office terminates, the inescapable conclusion is that any person claiming the rights of public office and enjoying the particular protections of the removal process as defined in the Constitution cannot be heard at the same time to contest the "constitutionality" of an impeachment conducted persuant to the terms of that document. As Mr. Justice Rehnquist has recently stated: "[W]here the grant of a substantive right is inextricably intertwined with the limitations on the procedures which are to be employed in determining that right, [one claiming rights under that grant] must take the bitter with the sweet." ${ }^{301}$ In the case of a presidential impeachment especially, since the procedural relationship between the office of the President and the other branches of government is undeniably intertwined with

297. See Fuentes v. Shevin, 407 U.S. 67, 82 (1972); Bell v. Burson, 402 U.S. 535, $541-42$ (1971). "The very nature of due process negates any concept of inflexible procedures universally applicable to every imaginable situation." Cafeteria Local 473 v. McElroy, 367 U.S. 886, 895 (1961); cf. Arnett v. Kennedy, 416 U.S 134, 154-55 (1974) (Rehnquist, J.).

298. Bell v. Burson, 402 U.S. 535,540 (1971).

299. See, e.g., Goldberg v. Kelly, 397 U.S. 254 (1970); Greene v. McElroy, 360

U.S. 474 (1959); Fahey v. Mallonee, 332 U.S. 245 (1947).

300. See Board of Regents of State Colleges v. Roth, 408 U.S. 564, 573 (1972);

Wisconsin v. Constantineau, 400 U.S. 433, 437 (1970).

301. Arnett v. Kennedy, 416 U.S. 134, 153-54 (1974) (Rehnquist, J.). 
the substantive creation of the office, the procedural rights which attach to that office are to be defined exclusively by the impeachment provisions as they appear exphcitly in the Constitution. These provisions do not incorporate a judicially defined due process requirement into the political machimery of impeachment.

However, this argument against the applicablility of the due process clause of the fifth amendment should not lead to the conclusion that the House and the Senate have the power to deal arbitrarily with the impeachment power. The concept of due process is important to the impeachment proceeding, not because it appears in the fifth amendment, but because it pervades this country's concept of justice and therefore acts as a powerful political constraint on congressmen who participate in the impeachment investigations and trial. Consequently, while the Senate may vote on an ad hoc basis to overrule particular evidentiary or procedural rules which conventionally are followed in the courts, ${ }^{302}$ it is highly unlikely that the Senate would deny an impeached civil officer well-recognized procedural safeguards except in rare cases. As the history of prior impeachment trials has shown, the substance of due process currently recognized in judicial proceedings generally will be recognized in impeachment procedings, with the single caveat that a party asserting the privilege or right is subject to the concepts of justice held by congressmen, and derivatively by their constituents, rather than by the judiciary.

This same line of reasoning applies to the full panoply of rights and privileges which an accused officer might attempt to derive from the fourth amendment or from the common law. Consider what would happen if the Congress were to authorize and conduct an unlawful search of the White House to gain possession of a President's personal papers. While the President could easily suppress that evidence in a subsequent trial of his criminal guilt in the courts, he could not compel its suppression before the Senate through the fourth amendinent. His only recourse would be to appeal to the conscience of the Congress and to the public commitment to the rule of law. If that appeal were unsuccessful, he might seek money damages directly upon the violation of his fourth amendment rights which he had suffered, ${ }^{303}$ but beyond that, it would exceed the powers of the courts either to intervene in the conduct of the impeachment trial or to reverse its verdict for any perceived constitutional infirmity. ${ }^{304}$ Even less likely is the possibility

302. See Senate Rules of Procedure, app. B infra.

303. Bivens v. Six Unknown Named Agents, 403 U.S. 388 (1971).

304. For the further ramifications of judicial review of the impeachment process, see Section VII accompanying notes 310-31 infra. 
that, it would exceed the powers of the courts either to intervene in order to protect evidentiary privileges that exist between a husband and wife or between an accused and his counsel. The social institutions which these privileges were created to protect simply cannot be given precedence over the nation's constitutional infrastructure which is designed to regulate the relationship among the governmental branches in an impeachment proceeding.

A further due process argument may conceivably be advanced by a public officer who has been subjected to impeachment investigations or by witnesses brought to testify in such trials: that certain demanded disclosures may jeopardize the rights of third parties and therefore cannot be compelled. On occasion-but not in the context of an impeachment trial-Presidents have objected to and resisted certain disclosures which would infringe the constitutional rights of third parties. For exaunple, President Jackson refused to disclose information to the House concernimg the conduct of a surveyor-general who had been removed from office on the purported grounds of fraudulent conduct. Jackson argued that disclosure would deprive a citizen of his basic right to "a public mvestigation in the presence of his accusers and the witnesses against him." 305 Later, President Tyler also claimed a privilege to withhold certain information on the basis of evidentiary privileges. In support of his refusal to supply the requested materials, Tyler stated that "these principles [evidentiary privileges] are as applicable to evidence sought by a legislature as to that required by a court."306 If this principle were not generally respected, it might be argued, Congress could fashion its own concept of procedural due process and then proceed, for example, to compel a witness to testify about a conversation concerning criminal conduct in which the witness participated. It

305. Executrive Privilege 181. Berger argued that Jackson's assertion that snch an inquiry was not "indispensable to the proper exercise of congressional power cannot be supported. Otherwise the President could cut off Congress' power to investigate executive misconduct merely by removing the officer." Id. at 182 .

306. 3 HINDs' $\$ 1885$, at 182 . In more recent years, both Truman and Eisenhower claimed privileges, based in part on due process considerations, to support directives prohibiting the disclosure of government information to congressional cominittees investigating the loyalty of federal employees. In a 1948 memorandum to all federal employees, President Truman directed that they were not to respond to inquiries involving the Employees' Loyalty Program. It is clear that the memorandum was prompted at least in part by due process considerations: "This is necessary . . . to protect Government personnel against the dissemination of unfounded or disproved allegations. It is necessary also in order to insure the fair and just disposition of loyalty cases." 13 Fed. Reg. 1359 (1948). Likewise Eisenhower's refusal to permit Defense Department personnel to testify at the Army-McCarthy hearings was prompted lárgely by due process considerations. 
would appear that a witness could thereby be effectively deprived of his right against self-incrimination, whereas the Supreine Court in Emspak v. United States ${ }^{307}$ and Quinn v. United States ${ }^{308}$ specifically has extended the privilege against self-incrimination to apply to a witness testifying before a congressional investigatory body. The modern doctrine of the privilege "extends to all manner of proceedings in which testimony is legally compellable, whether litigious or not and whether ex parte or otherwise." ${ }^{\prime 30}$

Without dismissing out of hand the due process arguments thus raised on behalf of third parties, it is contended that any effort to exclude evidence on such grounds froin an impeachment proceeding inust bear a nearly insurmountable burden of persuasion whenever that evidence is deeined significant to the resolution of the impeachment issue. This result is dictated both by the extraordinary nature of the impeachment proceeding and by the ability of a court to suppress or contradict the congressional testimony in a subsequent trial if that should prove necessary to vindicate the rights of third panties. Any earlier intervention by the courts into the impeachment process, however, on the pretense of supplying that proceeding with a given ineasure of due process, must be perceived and disimissd as premature and extra-constitutional.

\section{IMPEACHMENT AND JUDICIAL REVIEW}

Until recently, it has not been suggested seriously that the Supreme Court would have the power to review the interlocutory or final decisions of the Senate in an impeachment trial. ${ }^{310}$ Nevertheless, as

307. 349 U.S. 190 (1955).

308. 349 U.S. 155 (1955).

309. 8 J. WIGMORE, EvideNCE $\S 2252$, at 327 (McNaughton ed. 1961).

The privilege against self-incrimination has not been exercised in American impeachment proceedings for several reasons. First although the privilege was incorporated into the fifth amendment, it was rarely used in early criminal cases. See id. § 2252. Second, although recognition of the privilege became more widespread toward the end of the nineteenth century, it was not until McCarthy v. Arndstem, 266 U.S. 34 (1924), that the privilege was also extended to civil trials.

In the case of public officials, however, the scope of the privilege remains substantially limited. The privilege does not extend to public documents or papers, as distinguished from purely personal documents and papers, on the basis that it would be an intolerable handicap for the government to be unable to discover what its own doings are. See 7 J. WIGMORE, supra $\$ 2259$ (c)(1). See also Note, Quasi Public Records and Self-Incrimination, 47 CoLUM. L. REv. 838 (1947). Consequently public officials, particularly the President, will be more likely to assert other privileges of confidentiality such as executive privilege rather than the privilege against self-imcrimination in seeking to prevent disclosure of information recorded in public documents.

310. For recent assertions that an impeachment judgment is reviewable, see $R$. 
the nation matures and its communal roots deepen, it becomes increasingly more reasonable to require the decisions of government to be "made in accordance with rules of law and somewhat less by political accommodation." ${ }^{111}$ One can anticipate that the political question doctrine, ${ }^{312}$ precluding judicial review of the decisions of a coordinate political department, is bound to recede as time goes on, ${ }^{313}$ and as its circumference contracts, the feasibility of allowing judicial review of decisions inade in the course of an impeachment proceeding inay well appear to be enhanced. It is suggested, however, that there exists a hard core of issues, extending beyond the conduct of foreign policy, in which perceived legitimacy of governmental institutions and decisions demands the final political resolution of problems by one or the other of the political branches. Over these matters judicial review should not extend. Inpeachment is such an issue.

A political question which evades judicial review is said to arise under any of six conditions: where the actual text of the Constitution commits the issue to other branches for determination, where judicially discoverable or manageable standards for resolving the issue are lacking, where the question cannot be resolved without presupposing an initial policy determination of a kind clearly calling for nonjudicial discretion, where judicial review would entail an expression of disrespect for other branches of government, where contradictory resolutions might cause embarrassment to the government as a whole, and where

Berger 103-21; I. Bryant, IMPEachment, Trials AND ERrors 182-97 (1972); Feerick, Impeaching Federal Judges: A Study of the Constitutional Provisions, 39 FordhaM L. REv. 1 (1970); Rezneck, Is Judicial Review of Impeachment Coming?, 60 A.B.A.J. 681 (1974); Comment, Presidential Impeachment and Judicial Review, 23 AM. U.L. REV. 9.59 (1974).

The more conventional view, however, has been to the contrary. Willoughby viewed impeachment as nonreviewable: "It is scarcely necessary to say that the proceeding and determinations of the Senate when sitting as a court of impeachment are not subject to review in any other court." $3 \mathrm{~W}$. WilloughBY, THE CoNSTitutional LAW OF THE UNTrED STATES 1451 (2d ed. 1929). Black expressed essentially the same view:

It will be perceived that the power to determine what crimes are impeachable rests very much with Congress. For the House, before preferring articles of impeachment, will decide whether the acts or conduct complained of constitute a "high crime or misdemeanor." And the Senate, in trying the case, will also have to consider the same question. If, in the judgment of the Senate, the offense charged is not impeachable, they will acquit; otherwise, upon sufficient proof and the concurrence of the necessary majority, they will convict. And in either case, there is no other power which can review or reverse their decision. H. BLaCK, Constitutional LAW 121-22 (1897).

311. Firmage, Law and the Indochina War: A Retrospective View, supra note 3, at 19.

312. See notes $314-31$ infra and accoinpanying text.

313. Firmage, Law and the Indochina War: A Retrospective View, supra nóte 3, at 19. 
there is need to adhere to a political decision already made. ${ }^{314}$ It is suggested that under all but perhaps the second of these criteria, every question which is material to an impeachment decision presents a political question not subject to judicial review.

In the first instance, the constitutional text expressly grants the exclusive power of impeachment to the houses of Congress. The power to impeach and convict is held solely by the House and the Senate. ${ }^{315}$ It would seem to be anomalous to contend that this power can be exercised only in compliance with the dictates of the Supreme Court.

This construction of the demonstrable constitutional commitment of the issue of impeachment to Congress lias been consistently ac= claimed by the courts and the commentators, and it clearly reflects the unambiguous intentions of the framers at the Constitutional Convention. Joseph Story, in his Commentaries, expressed the common view of the early writers that Congress, not the courts, possessed a textual grant of constitutional authority to resolve any question of impeachmont: "The true exposition of the Constitution on [this point] is brought before the learned reader as matters still sub judice, the final decision of which may be reasonably left to the high tribunal constituting the court of impeachment when the occasion shall arise."316 This view is amply supported by the record of the Convention. Impeachment, as originally proposed, was to be within the jurisdiction of the "National Judiciary."317 After much discussion, lowever, impeachment jurisdiction was taken away from judicial cognizance and vested solely in Congress. ${ }^{318}$ The debates outline the reasons for the change. First, the judiciary has the power to proceed under an indictment against an accused at the same time that lie is the subject of an impeachment proceeding, and it was considered undesirable that the courts should ententaim two proceedings at the same time agamst one individual. ${ }^{319}$ Second, the framers recognized that impeachment was nonreviewable and defended this provision against the argument that

314. See Baker v. Carr, 369 U.S. 186, 217 (1961).

315. U.S. CoNsT. art. $1, \S 2$, cl. 5 ; id. $\$ 3$, cl. 6.

316. $1 \mathrm{~J}$. STORY $\S 805$, at 587 .

317. Resd. that a National Judiciary be established to consist of one or more supreme tribunals, and of inferior tribunals to be chosen by the National Legislature... that the jurisdiction of the inferior tribnnals shall be to hear and determine in the first instance, and of the supreme tribunal to hear and determine in the dernier resort . . impeachments of any National Officers. . . . 1 ReConps 21-22.

318. 2 id. at $186,493,547$.

319. "A conclusive reason for making the Senate instead of the Supreme Court the judge of impeachments, was that the latter was to try the President after the trial of the impeachment." Id. at 500 (remarks of Gouverneur Morris). 
it would subject the Executive to tenure at the mere pleasure of the legislature, ${ }^{320}$ for the assumption could not be indulged that the Senate would abuse its power:

[N]o other tribunal than the Senate could be trusted. The Supreme Court were too few in number and might be warped and corrupted. [Madison] was agst. a dependence of the Executive on the Legislature, considering the Legislative tyranny the great danger to be apprehended; but there could be no danger that the Senate would say untruly on their oaths that the President was guilty of crimes or facts, especially as in four years he can be turned out. ${ }^{321}$

Finally, it was suggested that it would be unwise to permit a body appoimted by the President to hold the ultimate power to try him on a bill of impeachment: "The Supreme Court [must be regarded] as improper to try the President, because the judges would be appointed by him." 322 For these reasons, judicial trial of impeachments was rejected by the framers of the Constitution.

The views expressed by the founders and supported historically by the weight of constitutional scholarship ${ }^{323}$ have been subsequently sustamed by the courts. ${ }^{324}$ Judge Ritter's unprecedented collateral attack on the Senate's impeachment conviction was firmly rejected by a unanimous opinion of the Court of Claims:

We think that when the provision that the Senate should have "the sole power to try all impeachments" was inserted in the Constitution, the word "sole" was used with a definite meaning and with the intention that no other tribunal should have any jurisdiction of the cases tried under the provisions for impeachment. The dictionary definition of the

320. [Madison] objected to a trial of the President by the Senate, especially as he was to be impeached by the other branch of the Legislature, and for any act which might be called a misdemeanor. The President under these circumstances was made improperly dependent. He would prefer the Supreme Court for the trial of impeachments. Id. at 551.

321. Id.

322. Id.

323. See T. Cooley, The General Principles of Constitutional Law 206 (1931); New YoRk CTTY Bar Association, LAW OF PRESIDENTIAL IMPEACHMENT 14-17 (1974); W. Rawle, A View of the Constitution (1829); C. WarReN, The Making of thB Constriution 658-64 (1928); Kurland, supra note 4, at 569-70; Ross, "Good Behavior" of Federal Judges, 12 U. KAN. CITY L. REv. 119, 125-26 (1944); Wechsler, Toward Neutral Principles of Constitutional Law, 73 HARv. L. REV. 1, 8 (1959); Bestor, Book Review, 49 WaSH. L. Rev. 255, 268 (1973); Fordham, Book Review, 47 U. So. CaL. L. REv, 673, 680-82 (1974).

324. But cf. State ex rel. Olson v. Langer, 65 N.D. 63, 256 N.W. 377 (1934) (reviewing Governor Langer's impeachment with regard to the term "disability" as grounds for impeachment); Fergusou v. Maddox, 114 Tex. 85, 263 S.W. 888 (1924) (holding that a court may determine whether the state Senate had exceeded its impeachment jurisdiction by acting on the basis of neither treason, bribery, nor high crimes and misdemeanors); Fordham, supra note 323 , at 681 . 
word "sole" is "being or acting without another" and we think it was intended that the Senate should act without any other tribunal having anything to do with the case. This would be the ordinary signification of the words and this construction is supported by a consideration of the proceedings of the Constitutional Convention and the uniform opinion of the authorities which have considered the matter. ${ }^{325}$

Given the foregoing arguments, there can be little doubt that there exists demonstrable textual commitment of the impeachment decision process to the legislature, bringing the exercise of that power securely within the realm of the political question doctrine.

Perhaps most important, judicial review of presidential impeachment would generate practical problems of the most grave and perhaps irremediable nature. There is an absolute need to abide by any political decision to impeach, once that verdict lias been reached by the Senate. Judicial review of such a verdict would cast the office of the Executive into an intolerable state of limbo as the succeeding President awaited the opimion of the Supreme Court on the correctness of the Senate's decision. Presidential legitimacy, never more necessary for reaffirmation, would be held in abeyance if not in a condition of further disintegration. Further, the painful reconciliation of Congress and the new President would be critically complicated by the brooding apparition of the former President's possible return. The government bureaucracy would be forced to ledge its activities in self-protection agamst the return of the ousted President; the gradually spreading paralysis of government, to some degree inevitable during congressional impeachment activity, would be continued. And if the former President were to be reinstated by judicial reversal, it is unimaginable that an effective relationship would ever be re-established between him and the Congress which had pronounced him guilty of the commission of impeachable offenses. ${ }^{326}$ In short, neither political nor bureaucratic

325. Ritter v. United States, 84 Ct. Cl. 293, 296 (1936), cert. denied, 300 U.S. 668 (1937).

326. Interposition of the courts to pass upon the legal sufficiency of articles of impeachment following their adoption by the House would considerably prolong the period of uncertainty in the leadership of government that impeachment of a President would necessarily produce; and judicial review after a judgment of conviction and removal by the Senate would cast doubt, with the greatest potential repercussions, on the fundamental question of who is entitled to hold the office of President of the United States in the period following the final vote in the Senate. These considerations support our basic conclusion, that the Constitution has committed exclusively and finally to the measured discretion of elected representatives the unique, quasi-judicial function of determining whether an elected or appointed officer of the United States must be removed from office on grounds of fitness. NEw YORK CITY BAR Association, supra note 323 , at 170 . 
levels of government could function under such conditions. The profoundly political nature of impeachment is nowhere more evident than in an analysis of the impropriety of judicial review of this seminal political act.

Moreover, the fundamentally political nature of the impeachment process should preclude the possibility of judicial review of intermediate as well as final determinations made by Congress in the exercise of its impeachment power. Interlocutory appeals of such congressional decisions, im addition, may be discounted on the further ground that the threat of repeated delays in trial, which such review would inevitably create, would stifle most attempts to exercise the impeachment power effectively as a political prophylactic. Of course, impeachment is lieavy political artillery which is not meant to operate too quickly. Nevertheless, it is designed to operate effectively, and a mutiplicity of interlocutory appeals by a President who wanted to "run out the clock" would threaten to stall seriously its basic operation and thus should not be permitted.

It has recently been suggested, however, that the direction in which the Court has moved through its intervention into areas previously considered to be beyond the scope of its jurisdiction warrants, if not demands, a similar extension of its authority into the realm of impeachment. ${ }^{327}$ The main proponents of this view have relied primarily upon statements in Powell v. McCormack ${ }^{328}$ and Baker v. $\mathrm{Carr}^{329}$ that a political question exists where judicially discoverable and manageable standards for resolving the problem are lacking. Thus, it

327. See note 310 supra.

328. 395 U.S. 486 (1969). Powell involved the expulsion of Congressman Adam Clayton Powell from the House of Representatives. The Court reached the merits uotwithstanding the constitutional delegation to Congress of the responsibility of judging the qualifications of its own members. Article I, section 2, clause 2 of the Constitution describes three qualifications that must be met by a Representative, and article I, section 5, clause 1 provides that "[e]ach House shall be the Judge of the . . Qualifications of its own Meunbers." It is submitted, however, that Powell cannot be extended to permit judicial review of impeachment, for the exercise of judicial review in Powell is distinguishable from its invocation in an impeachment proceeding. In Powell, the Court did not find a "textually demonstrable commitment" of a discretionary power to each House. See New York CITY Bar Association, supra note 323, at 169. The constitutional text and the framers' own interpretation are quite different with regard to impeachment. Although the Constitution limits impeachment to "Treason, Bribery, or other high Crimes and Misdemeanors," U.S. CoNST. art. II, $\S 4$, it also grants to Congress the "sole" authority to apply those terms, id. art. I, $\$ 2$, cl. 5. Rather than limiting impeachment to grounds unambiguously circumscribed, the framers delegated a significant degree of political discretion to Congress, a fact which could not be shown in Powell.

329. 369 U.S. 186 (1962). 
is argued that since the interpretation of the term "high Crimes and Misdemeanors" is susceptive to principled judicial standards, the political question doctrine should not be invoked in derogation of judicial jurisdiction to review the congressional interpretation of this phrase. This argument, however, cannot stand. This very matter was specifically considered and rejected in the Convention. Broad political judgment, not judicial interpretation, was thought necessary to determine the scope of this phrase's application to particular offenses: "[O]n this basis, the propriety of the exercise of these powers in a particular case would present a political question, regardless of whether "high Crimes and Misdemeanors' is given a broad or a narrow meaning." Beyond that, the argument looks only to one of six criteria set forth for the existence of a political question, and from that simgle proposition it incorrectly infers that, since a political question exists where suitable judicial standards are lacking, it necessarily. follows that the doctrine can be disregarded wherever manageable judicial standards are present. That extrapolation, however, is fallacious: if sucl a conclusion were reached, it would foreclose the political question doctrine wherever decisions capable of formal rationalization are made in either of the other branclies of government.

It is not disputed that Baker and Powell have significantly contributed to the erosion of the political question doctrine. Nevertheless, the erosion cannot wash away those powers textually committed by the Constitution solely to the political branches of government. The nub of the political question doctrine is not simply that the courts will not intervene where judicial standards are vague, but rather that in a democratic community certain decisions, because of their inherently political nature, must be left to political branclies of the government. In recognizing this principle, the Count of Claims has concluded that impeachment is indeed such a political process which is not susceptible to judicial review:

While the Senate in one sense acts as a court on the trial of an impeachment, it is essentially a political body and in its actions is influenced by the views of its members on the public welfare. The courts, on the other hand, are expected to render their decisions according to the law regardless of the consequences. This must have been realized by the members of the Constitutional Convention and in rejecting proposals to have impeachments tried by a court composed of regularly appointed judges we think it avoided the possibility of unseemly conflicts

330. See New York CtTY BAR Association, supra note 323, at 169 (emphasis added). 
between a political body such as the Senate and the judicial tribunals which might determine the case on different primciples. ${ }^{331}$

\section{IMPEACHMENT AND INDICTMENT}

It has recently been questioned whether or not the President, the Vice-President or any civil officer can be indicted before impeachment, conviction, and removal from office. The issue involves the interpretation of article I, section 3 of the Constitution: "Judgment in Cases of Impeachment shall not extend further than to removal from Office, and disqualification . . . but the Panty convicted shall nevertheless be liable and subject to Indictment, Trial, Judgment and Punishment, according to Law."332 The debate involves the "nevertheless" clause, which under one reading might only preclude the impeached from asserting double jeopardy as a criminal defense or on a broader reading may also extend to establishing a precedence of impeachinent and conviotion before any subsequent criminal indictment. Berger, in considering the issue, directly limits the clause to the first interpretation:

The implication of "shall nevertheless be liable" to indictment is that the given party is already liable, that the words are merely designed to preserve existing criminal liability rather than to qualify it. It would be unreasonable to attribute to the Framers an intention to insulate officers from criminal liability by mere appointment to office; like all men they are responsible under the law..$^{333}$

This is consistent with the major body of thought on the question, as few have been willing to bestow an absolute immunity from prosecution upon all public servants during their tenure in office:

Otherwise, it might be a matter of extreme doubt wliether . . . a second trial for the same offense could be liad, either after an acquittal or a conviction, in the court of impeachments.

The Constitution . . . lias wisely subjected the party to trial in the conmon criminal tribunals, for the purpose of receiving such punishment

331. Ritter v. United States, 84 Ct. Cl. 293, 299 (1936), cert. denied, 300 U.S. 668 (1937).

332. U.S. ConST. art. I, § 3, cl. 7. Special Prosecutor Leon Jaworski advised the grand jury not to indict President Nixon: "It was researched at the time and the conclusion was that legal doubt on the question was so substantial that a move to indict a sitting President would touch off a legal battle of gigantic proportions." N.Y. Times, Mar. 12, 1974, at 24, col. 1. Although the issue was presented by the President's cross-petition for certiorari in United States v. Nixon, 94 S. Ct. 3090, 3097 n.2 (1974), the Court found the resolution thereof unnecessary and hence dismissed the crosspetition as improvidently granted. Id.

333. Berger, supra note 277 , at 1123. 
as ordinarily belongs to the offense. ${ }^{334}$

And there is little reason to concede such an immunity. The founders' fear of a despotic Executive is well known, and it militates directly against the granting of such executive immunity. ${ }^{335}$ In early congressional debate regarding the limited immunity granted to congressnien, ${ }^{336}$ Charles Pinckney commented: "No privilege of this kind was intended for your Executive . . . . The Convention . . . well knew that . . . no subject had been more abused than privilege. They therefore deterinined to set the example, in merely limiting privilege to what was necessary, and no inore."337 With a view to assuaging the same fear, Wilson assured the Pennsylvania Ratification Convention that "not a single privilege is annexed to [the President's] character."338

The courts have also concluded that no officer is immune from responsibility under the civil and criminal law, regardless of the repercussions of conviction and punishment. The Supreme Court in United States $v$. Lee, ${ }^{330}$ a civil suit against appointed military officers acting under a presidential directive, stated:

[N]o officer of the law may set that law at defiance with impunity. All the officers of governmeut, from the highest to the lowest . . . are bound to obey it.

It is the only supreme power in our system of government, and every man who by accepting office participates in its functions is only the inore strongly bound to submit to that supremacy, and to observe

334. 1 J. STORY §§ 782-83, at 571-72.

335. George Mason, in speaking to the need to broaden the impeachment provision beyond treason and bribery, noted that "attempts to subvert the Constitution may not be [treasonous]." 2 ReCorDS 550. Madison advocated that "some provision should be made for defending the community [against] the incapacity, negligence or perfidy of the Chief Magistrate. The limitation of the period of his service . . . was not a sufficient security. . . . He might pervert his administration into a scheme of peculation or oppression." Id. at 65-66.

336. "The Senators and Representatives ... shall in all Cases, except Treason, Felony or Breach of the Peace, be privileged from arrest during their Attendance at the Session of their respective Houses, and in going to and returning from the same . . . U.S. Const. art. I, $\S 6$, cl. 1.

337. 10 ANnals of Cong. 74 (1800) [1799-1801].

338. 2 J. ElLIOTT 480.

339. 106 U.S. 196 (1882). The Court has recently affirmed that position in dicta in O'Shea v. Littleton, 414 U.S. 488 (1974), a civil suit against a federal judge. The case, dismissed for failure to demonstrate a case and controversy, contained ele. inents of alleged civil and criminal misconduct:

We have never held that the performance of the duties of judicial, legislative, or executive officers, requires or contemplates the immunization of otherwise criminal deprivations of constitutional rights. . . . On the contrary, the judicially fashioned doctrine of official immunity does not reach so far as to immunize criminal conduct proscribed by an Act of Congress. Id. at 503 (citations omitted). 
the limitations which it imposes upon the exercise of the authority which it gives. ${ }^{340}$

Likewise, in Gravel v. United States, ${ }^{341}$ a Senator assented a constitutional privilege to disregard a subpoena requiring him to appear as a witness before a federal grand jury. The Court stated: "[T]he constitutional freedom from arrest does not exeinpt Meinbers of Congress from the operation of the ordinary criminal laws, even though imprisonment may prevent or interfere with the performance of their duties as Meinbers." ${ }^{342}$ Thus, elected and appointed officers alike are not above the law, even where conviction and imprisonment may interfere with the execution of the duties of their office.

It also appears well settled that a conviction in the law courts is not synonymous with impeachment and removal from office. Precedent exists where elected officials and civil officers have been prosecuted without being either impeached or expelled, thereby suggesting at least the possibility that presidential impeachment and removal need not precede indictment. In Burton v. United States, ${ }^{343}$ a United States Senator appealed a conviction for bribery, arguing that conviction would necessarily lead to his expulsion from the Senate whereas the Constitution granted the Senate the sole power of expulsion. The Court, quoting United States $v$. Lee with approval, rejected his contention and found no violation of separation of powers. ${ }^{344}$ Similarly, there have been several cases where federal judges have been indicted, and in some instances convicted, yet never impeached. ${ }^{345}$ Most recently, the question of the criminal indiotability of an incumbent federal judge was raised in United States $v$. Isaacs. ${ }^{346}$ Co-defendant Kerner, a federal district judge and a former Governor of Illinois, argued that because conviction on criminal charges is "tantamount to removal from office, federal courts are without jurisdiction over the person." ${ }^{347}$ The court, however, again rejected the defendant's claim of immunity:

340. 106 U.S. at 220.

341. 408 U.S. 606 (1972).

342. $1 d$. at 615 .

343. 202 U.S. 344 (1906).

344. Id. at 368 .

345. For instance, Manton of the Court of Appeals for the Second Circuit was criminally indicted but never impeached. See J. BORKIN, THE CORRUPT JUDGe 25 (Meridian ed. 1966). Other examples are Davis of the Court of Appeals for the Third Circuit, who was indicted as an incumbent but sever convicted or impeached, id. at 97, and Johnson of the Eastern District of Pennsylvania, who was convicted without being impeached, id. at 141.

346. 493 F.2d 1124 ( 7 th Cir. 1974).

347. Id. at $1140-41$. 
[T]hat an impeached judge is "subject to Indictment, Trial, Judgment and Punishment, according to Law" does not mean that a judge may not be indicted and tried without impeachment first. The purpose of the phrase may be to assure that after impeachment a trial on criminal charges is not foreclosed by the principle of double jeopardy, or it may be to differentiate the provisions of the Constitution froin the English practice of impeachment. ${ }^{348}$

After considering the precedents, the count unequivocally approved pre-impeachment indictment of any civil officer:

[W] hatever immunities or privileges the Constitution confers for the purpose of assuring the independence of the co-equal branches of government they do not exempt the meinbers of those branches "from the operation of the ordinary criminal laws." Criminal conduct is not part of the necessary functions performed by public officials. Punishment for that conduct will not interfere with the legitimate operation of a branch of government. ${ }^{349}$

Nevertheless, it has been argued that whereas lesser officers inay be subject to indiotment before impeachment, the President is not. This thesis has been presented most persuasively by Professor Bickel and is premised upon the theory that "[i]n the presidency is embodied the contimuity and indestructibility of the state."350 Reasoning therefrom, Bickel has argued that "the presidency cannot be conduoted from jail, nor can it be effectively carried on while an incumbent is defending himself in a criminal trial."351 Raoul Berger in reply argued: "While it is true that the presidenoy 'cannot be conducted from jail,' it is unrealistio to postulate that a convicted President could not be released on bail pending appeal .... If the President lacked the sensitivity to resign, an impeachment could speedily follow . . . ."352

Still, in reachimg this conclusion, one need not ignore the fact that certain costs attach to a constitutional interpretation that the President is subject to criminal processes before or conteinporaneous with impeachment preceedings. This interpretation may result in some incapacitation of the executive office, but to raise the spectre of total im-

348. Id at 1142 .

349. Id. at 1144 .

350. Bickel, The Constitutional Tangle, The New RepubLIC, Oct. 6, 1973, at $14,15$.

351. Id. at 15.

352. Berger, supra note 277 , at 1133.

It is we who have surrounded the President with a mystique that has contributed heavily to an "imperial presidency." When we forget that the President is "but a man ... . but a citizen" we are on the road that has unfailingly led to Caesarism. It was because the Founders had learned this lesson from history that presidential powers were enumerated aud limited, and that immunity from arrest was altogether withheld. Id. at 1136 (citations ormitted). 
mobilization of executive action is to project the matter absurdly out of proportion. Moreover, the "continuity and indestructibility of the state" would seem to be linked indissolubly to the perceived legitimacy of a government whose officers are required to operate without immunity based upon special status. It is our adherence to constitutional institutions, not to the elevated personalities of our leaders, which provides an iron rod of support from a republican past to a republican future. Neither a natural reading of the Constitution and the "nevertheless" clause nor precedent nor public policy requires that impeachment and removal precede indictment, even-perhaps especially -when the accused is the President.

\section{RESIGNATION AND IMPEACHMENT}

The resignation of President Nixon has precipitated debate about the effectiveness of the impeachment proceeding as a constitutional means of removing civil officers for official misconduct. The dialogue speaks to both the issues of whether the impeachment process may be continued after the accused has resigned and whether the impeachment process is too unwieldy to provide an efficient means of removing offending officers. It is suggested that the impeachment process may constitutionally be continued after an accused has resigned (1) although public policy considerations may require that the proceeding be discontinued nonetheless) and that, (2) although the impeachment procedures are cumbersome and deserve to be reviewed and amended, the overall effectiveness of the impeachment process as a ineans of removing civil officers from office for misconduot may be enhanced rather than diminished by a resignation in anticipation of inevitable conviction and removal. Resignation should not be viewed as being extraordinary, extra-legal, ${ }^{353}$ alien to, or even apant from, the impeachment process. The Constitution provides for resignations precipitated directly by the impeachment process, ${ }^{354}$ and they are much more frequent than convictions and removals. Under proper circumstances, resignation is a fitting and foreseeable conclusion to impeachment, a coherent part of the process.

In addition to President Nixon, many civil officers have resigned under the pressure of an impeachment proceeding against them, and the question of the continuation of post-resignation impeachment pro-

- 353. Cf. Kurland, supra note 4, at 578. Kurland has stated that where "resignation is not a voluntary act but is in effect forced upon thein by extra-legal pressures, the resignation is an extra-constitutional means of removal." $I d$.

354. U.S. CoNST. art. II, $\S 1$, cl. 6. 
ceedings has frequently been discussed. In the earliest impeachment, that of Senator Blount, whose reinoval was actually accoinplished by Senate expulsion, the issue of continuing the impeachment process after resignation was vigorously debated. The argninent that Congress has jurisdiction to continue the impeachment process after an accused has resigned was made by Congressinan Bayard:

If the impeachment were regular and maintainable when preferred, I apprehend no subsequent event, grounded on the willful act, or caused by the delinquency of the party, cau vitiate or obstruct the proceeding. Otherwise, the party, by resignation or the commission of some offense which merited and occasioned his expulsion, might secure his impunity. This is against one of the sagest maxims of the law, which does not allow a man to derive a benefit from his own wrong. ${ }^{355}$

This point was effectively conceded by both parties, while counsel for the respondent argued that Blount could not both be expelled from the Senate under its own rules ${ }^{356}$ and then later disqualified from holding office by an impeachment conviction. ${ }^{357}$ Blount was ultimately acquitted on the basis that a Senator was not a civil officer under the inpeachment clause.

In the Belknap trial, the question arose in the context of whether a private citizen who had "formerly held an office nnay be impeached for acts done as an incumbent of that office." Story, that such an exercise of the impeachment power slould not be possible:

All the reasons upon which the proceeding was supposed to be necessary were applicable only to a man who wielded at the moinent the power of the Government, when only it was necessary to put in motion the great power of the people, as organized in the House of Representatives, to bring him to justice. It is a shocking abuse of power to direct so overwhelming a force against a private man. ${ }^{359}$

In rebuttal, however, the House managers contended that the impeachment power does not depend upon the condition or the status of the

355. 3 Hinds' § 2317 , at 678 .

356. At the time of the Senate trial, Blount was no longer a Senator, having been expelled from the Senate under its own rules. Id.

357. Counsel for the respondent, Mr. Dallas, protested: "I certainly shall never contend that an officer may first commit an offense and afterwards avoid punishment by resigning his office; but the defendant has been expelled. Can he be reinoved at one trial and disqualified at another for the same offense?" Id.

358. Id. § 2007.

359. Id. at 313. It was further argued that "the only purpose of impeachment is to remove a man from office, when the man is out of office the object of impeachment ceases, and the proceeding must abate. There would be no further object to attain by the proceeding." $I d$. at 318 . 
culprit at the time of trial in the Senate, so long as jurisdiction had been properly obtained over the respondent by the House:

[T] of public official national wrongdoers, a power conferred for the highest reasons of state and on fullest deliberation, to interpose by its judgment a perpetual barrier against the return to power of great political offenders, does not depend upon the consent of the culprit, does not depend upon the accidental circumstance that the evidence of the crime is not discovered until after the official term has expired or toward the close of that tern, but is a perpetual power, hanging over the guilty officer during his whole subsequent life, restricted in its exercise ouly by the discretion of the Senate itself and the necessity of the concurrence of both branches, the requirement of a two-thirds' vote for conviction, and the constitutional limitation of the punishment. ${ }^{360}$

[W] claim that the House of Representatives having obtained jurisdiction of the subject-matter by instituting these proceedings against the defendant, he could no nore defeat them by resigning midway than lie could defeat the Constitution itself. ${ }^{361}$

After consideration, the Senate concluded that Belknap was subject to the impeachment process notwithstanding his prior resignation. ${ }^{362}$

Consistent with this conclusion, when impeachment investigations have been discontinued after the accused has resigned, ${ }^{363}$ the Congress has reserved its discretionary authority to continue the impeachment proceeding despite the resignation. In the English impeachment, for exainple, although the Senate voted after his resignation to discontinue the proceeding, the nnanagers expressed the opimon that "the resignation of Judge Enghish in no way affects the right of the Senate, sitting as a court of impeachment, to hear and determine said impeachment charges." ${ }^{364}$ Thus, the Congress has been adamant in retaining impeachment jurisdiction over an accused despite his resignation from office.

Three arguinents can be advanced in support of the claim that post-resignation impeachment is not an idle or vindictive gesture. First, as has been argued in previous impeachment cases, the impeachinent judgment may extend to both removal from office and disqual-

360. Id. at $315-16$.

361. Id. at 317 .

362. Id. at 321.

363. See, e.g., 6 CanNon's $\S 526$ (Hanford); id. $\S 547$ (English); id. $\$ 550$ (Winslow); 3 HINDs' $\$ 2489$ (Stephens); id. $\$ 2500$ (Irwin); id. $\$ 2512$ (Busteed); id. $\$ 2509$ (Durell).

364. 6 CANNON'S $\$ 547$. 
ification from holding any further office. Resignation accomplishes only the first objective. Second, the accused may stand to receive emoluments and benefits upon resignation which would not otherwise be available should he be removed by conviction. Thus, in the impeachment proceeding of Judge Hanford in 1912, the Judiciary Committee recommended discontinuance of the impeachment proceedings after the Judge had resigned upon the express reason that he was not entitled to receive any retirement benefits: " $[\mathrm{H}]$ is resignation brings him no emolument or reward and involves no expenditure of public money."305 But in the case of a presidential resignation incident to an impeachment proceeding, the presence of emoluments and benefits, which are available notwithstanding the fact that the resignation is not in reality voluntary, may demand a contrary result, and continuing the impeachment process could terminate the expenditure of public inoney to a President whose official misconduct resulted in resignation. Third, looking at the subject jurisprudentially, impeachment in England and America was developed to enforce affirmatively the constitutional bounds of legitimate official action. Accordingly, impeachment as a political tool serves to maintaim government under law; its purpose extends beyond the scope of any particular case to its effect on the constitutional structure of the state. Taking the impeachment process to conviction may have the effect of setting powerful precedential limitations on presidential conduct; Senate conviction after resignation represents the inost awesome judgment that certain behavior is beyond the pale.

Although the impeachment process may constitutionally be continued after the accused has resigned, several arguments can be made against such conduct under certain circumstances. First, when the offense charged constitutes an imdictable crime, after resignation it may be most practicable to allow the judicial process to be utilized to conclude the matter on conventional criminal grounds. The framers clearly intended the judicial process to supplement the impeachment process, even-perhaps especially-against the acts of the highest officials. Moreover, a judicial conviction may provide an alternative mode for creating precedent which would restrain future conduct of the office. Second, Congress has alternative means to limit, at least prospectively, the retirement beneffits for civil officers who have reesigned under threat of impeachment. Third, when the offense charged may be nonindictable, such as abuse of powers or failure to comply with congressional subpoenas in an impeachment proceeding, Congress 
could pass a precedential resolution indicating the impeachable nature of such acts; it could then censure the accused officer after his resignation rather than prolonging the impeachment trial itself. ${ }^{366}$ The availability of these law-1naking alternatives may support an argnment against continuing the impeachment process when the accused has resigned, but only to the extent that these alternatives are actually utilized are the purposes of the impeachment process thereby fulfilled.

No myth of mantyrdom should be allowed to surround one not worthy of such a fate. The absence of factual ambiguity inust be achieved either by confession connected with resignation or by the processes discussed previously, or by some combination thereof. Otherwise, the discontinuation of the impeachment process upon the resignation of the accused, if followed by a failure of the courts, the President, the Justice Department, and the Congress to further effectuate alternatives to impeachment, together would demonstrate the inadequacy of the system properly to enforce the rule of law as the cohesive element of the state.

Aside from the critical and complex issue as to how the lawmaking, precedential purposes of impeachment can best be accomplished, an analysis of resignation imcident to impeachment demonstrates that the limited and more simple purpose of inpeachment to remove high officials from office in order to end a particular abuse of office is not frustrated by resignation. Joseph Borkin has noted that "[o]f the fifty-five judges [subject to a congressional inquiry] ... seventeen . . . resigned at one stage or another on the conduct of the investigation . . . . Added to this are the undetermined number of judges who resigned upon mere threat of inquiry; for them there are no adequate records." ${ }^{\text {367 }}$ A sinple listing of the resignations which

366. The House of Representatives acted in this manner, though with overcaution and consequently with much less normative impact, by ordering the printing of the final report of the House Committee on the Judiciary as a House document rather than following the usual procedure of printing it as a document of the Judiciary Com. mittee. This reflects to some ambiguous degree House ratification of the Coinmittee's fact-finding conclusions and impeachinent recommendation. The Committee report presents an overwhelming factual case establishing the commission of impeachable offenses, but the report falls far short of a vote of impeachment after resignation. Where offenses, both criminally indictable and nonindictable, are as serious as those established, a vote of censure after resignation, rather than a continuation of impeach Inent proceedings, is precedentially harmful to the rule of law. In such a situation, censure is so mild when compared with the seriousness of the offenses as to be institutionally harmful, arguably indicating congressional timidity toward the concept of equality before the law when high political figures are involved. See H.R. REP. No. 1305, 93d Cong., 2d Sess. (1974).

367. J. BORKIN, supra note 345, at 204. 
have followed impeachment investigations suggests that the impeachment power of Congress has been successfully employed as a powerful constitutional means of removing civil officers from office where misconduct is apparent. Among the judges who have resigned directly as a result of an impeachment inquiry are Judges Stephens, Irwin, Bustud, Durell, Hanford, Wright, Enghish, and Winslow. ${ }^{308}$ Secretary of War Belknap resigned incident to an impeachment investigation, ${ }^{369}$ as did a collector of customs. ${ }^{370}$ Finally, and most significantly, President Nixon resigned after repeated statements that he had no intention of so doing, once it appeared that impeachment in the House and conviction in the Senate were inevitable. Although the Judiciary Committees in these cases either have found it unnecessary to report to the House or have reported with a recommendation of discontinuance after resignation, the possibility of imcluding findings or resolutions in such reports often provides an effective alternative to continuing the impeachment process. ${ }^{371}$

Resignation need not represent the defeat of the impeachment process but instead may be just one aspect of its successful operation. Although the resignation of a corrupt officer, taken alone, does not fulfill all the purposes of impeachment, resignation does accomplish several important functions of impeachment without precluding the use of other available means to fulfill its further ends.

\section{Pardon ANd IMPEACHMENT}

The pardon extended Mr. Nixon by President Ford raises further questions concerning both the effectiveness of the impeachment process as a means of constraining executive power and the validity of the democratic premise that law does in truth apply equally to all men. The questions are precipitated, in part, by confusion concerning the scope of the presidential pardon power, with regard to which the following points may be made in respect to impeachments: (1) a pardon is an act of grace primarily intended to be used in cases where strict ap-

368. Judges Stephens in 1818,3 Hinds' $\S 2489$, Irwin in 1859 , id. $\S 2500$, Busteed in 1873, id. $\$ 2512$, Durell in 1875, id. $\S 2509$, Hanford in 1912, 6 CanNon's $\S$ 526 , Wright in 1914, id. $\S 528$, English in 1926, id. $\S 547$, and Winslow in 1929, id. $\S 550$, all resigned as a result of the initiation of impeachment proceedings.

369. 3 Hinds' $\$ 2445$.

370. 6 Cannon's $\$ 539$ (Chase).

371. In the case of Circuit Court Judge Hanford, who resigned in 1912, the House Judiciary Committee, in recornmending the discontinuation of the proceeding, "declared him to be disqualified for his position, thereby presenting an official pronouncement as to the Judge's responsibility for misconduct in office." Id. $\S 526$, at 745 . 
plication of the criminal code would not serve justice; (2) the founding fatlers intended to except from the presidential pardon power those cases involving public misconduct rising to the level of impeachable offenses and no reason is evident to depart from such a policy; (3) the scope of the pardon power is limited to remitting criminal punishment but does not blot out the offender's guilt; and (4) the pardon power ought not to be exercised to circumvent a full investigation into the misconduct of public officials, but should only be invoked either after conviction to remit punishment or before trial to secure the testimony of a co-conspirator in the extraordimary situation in which justice is better served by so doing.

\section{A. Historical Analysis of Pardon}

The earliest statement of the English law of impeachment was made in the thirteenth century by Bracton who stated with respect to the effect of a pardon:

[A] person is not restored except to the king's peace alone .... . For the king cannot grant a pardon with injury or damage to others. $\mathrm{He}$ Inay give what is his own, that is his protection, ... but that which is another's he cannot give by his own grace. Likewise a person justly and duly outlawed is not restored to anything except to the king's peace .....372

In the case of impeachment, where the offense was deemed to be against the public rather than the crown, the king's prerogative of pardoning was substantially limited. Story, in his Commentaries on the Constitution, summarized the Enghish law of pardon incident to impeachment: "In England . . . no pardon can be pleaded in bar of an impeachment. But the king inay, after conviction upon an impeachment, pardon the offender. His prerogative, therefore, cannot prevent the disgrace of conviction; but it may avert its effects, and restore the offender to his credit."373

The effect of a pardon, therefore, did not blot out, much less prevent, the establishment of the felon's guilt by trial and conviction, but merely reestablished his legal capacity as that of an innocent man, an important matter under English law since conviction destroyed many of the civil rights of the offender. ${ }^{374}$ In the case of a public servant whose offense was against the public he purportedly served, the king's pardon could not obviate the disgrace of conviction after impeachment,

372. Williston, Does a Pardon Blot Out Guilt?, 28 HARv. L. REv. 647, 649 (1915).

373. 2 J. STORY \& 1502 , at 336.

374. Williston, supra note 372 , at 650 . 
which served a prophylactic function in the effort to achieve "ministerial responsibility and primacy over the king . . .."375 The preventive functions of the impeachment process demanded the proper timing of a grant of pardon which did not obstruct full disclosure of wrongdoing.

Contrary to the English experience, Americans adopted the view that sovereignty with all its perquisites, including the power to remit pumishment, rested finally with the people. Morris, in the Constitutional Convention, noted that "this Magistrate [the President] is not the King but the prime Minister. The people are the King." ${ }^{.378}$ As a result, the theoretical foundation of the English law of pardon, that the king's peace was the king's to enforce, or its violation to forgive, became inapplicable in the American situation. Nevertheless, pardon power was discussed in the constitutional debate as an essential element of democratic government. It was argued by James Iredell in the North Carolina ratifying convention that the proper exercise of the pardon power in a republican form of government was not to protect felons with powerful friends, but to protect the body politic froin possible injustices that may result from inflexible application of the laws. ${ }^{\mathbf{3 7 7}}$

In the case of a public servant who had committed "high Crimes and Misdemeanors," Iredell, who later served on the Supreme Court, argued that a pardon would be inappropriate in that it would not serve justice:

After [an impeachment] trial thus solemnly conducted, it is not probable that it would happen once in a thousand times that a man actually convicted would be entitled to mercy; and if the President had the power of pardoning in such a case, this great check upon high officers of state would lose much of its influence. It seems, therefore, proper that the general power of pardoning should be abridged in this particular instance. ${ }^{378}$

Accordingly, the presidential pardon power that was incorporated into the Constitution excepted cases of impeachment: "The President . . . shall have Power to grant Reprieves and Pardons for Offenses against the United States, except in Cases of Impeachment." "379

Justice Story, in analyzing the historical creation of the pardon power, stated that the framers intended by the exception to take "from the President every temptation to abuse it in cases of political and

375. Firmage, supra note 14, at 686.

376. 2 RECORDS 69.

377. 4 J. Elliotr 110-12.

378. Id. at 113-14.

379. U.S. CoNST. art. II, § 2, cl. 1. 
official offences by persons in the public service."380 Story concluded that

[i]t is of great consequence, that the President should not have the power of preventing a thorough investigation of their conduct, or of securing thein against the disgrace of a public conviction by impeachment if they should deserve it. The Constitution has, therefore, wisely interposed this check upon his power, so that he cannot, by any corrupt coalition with favorites, or dependents in high offices, screen thein from punishment. ${ }^{381}$

\section{B. Elements of Pardon}

A pardon lias been defined as "thc private, thougli official act" of forgiveness "by the executive magistrate ... [whicli] exempts the individual" who accepts the proffer from the legal punishment normally attached to the offense. ${ }^{382}$ Mucli of the debate concerning the presidential pardon power involves questions concerning the scope of the power and the appropriate timing of a grant of pardon. The Supreme Court's imprecise treatment of these issues is in part responsible for the confusion over the presidential pardon power.

Support for the view that a pardon blots out guilt as well as remits punishment has been thought to exist in the Supreane Court's opinion in Ex parte Garland. ${ }^{383}$ In that case, the petitioner argued that the effect of a pardon "is to obliterate the past, to leave no trace of the offense, and to place the offender exactly in the position which he occupied before the offense was committed, or in which he would have been if he had not committed the offense." "384 Seemingly adopting the petitioner's reasoning, the Court stated in dicta that "a pardon reaclies both the punishment prescribed for the offense and the guilt of the offender; and when the pardon is full, it releases the punishment and blots out the existence of guilt, so that in the eye of the law the offender is innocent as if had never committed the offense." 385 The presidential "pardoning" proclamation in that case, however, was "under the aninesty power delegated by Congress in 1862 as well as under this pardoning power." 386 The precedential value of Garland in a simple pardon is therefore slight.

380. 2 J. STORY § 1501.

381. Id.

382. United States v. Wilson, 32 U.S. (7 Pet.) 150, 160 (1833).

383. Ex parte Garland, 71 U.S. (4 Wall.) 333 (1867).

384. Id. at 351 .

385. Id. at 380.

386. Freeman, An Historical Justification and Legal Basis for Amnesty Today, 1971 LAW AND THe SOCIAL ORDER 515, 522. 
Courts, in distinguishing between amnesty and pardon, have stated that whereas amnesty may blot out guilt by removing the offense, a pardon merely remits punishment. In United States $v$. Basset, ${ }^{387}$ amnesty and pardon were distinguished on the ground that a pardon does not extinguish guilt:

The word "amnesty" is defined thus: "An act of oblivion of past offenses, granted by the government to those who have been guilty of any neglect or crime, usually upon condition that they return to their duty within a certain period."

A pardon relieves an offender from the consequences of an offense of which he has been convicted, while amnesty obliterates an offense before conviction; and in such case, he stands before the law precisely as though he had committed no offense. ${ }^{388}$

The Supreme Court in Burdick v. United States ${ }^{389}$ apparently adopted the same view that a pardon does not extinguish guilt notwithstanding the dicta in Garland:

The one [amnesty] overlooks offense; the other [pardon] remits punishment. The first is usually addressed to crimes against the sovereignty of the State, to political offenses, forgiveness being deemed more expedient for the public welfare than prosecution and punishment. The second condones infractions of the peace of the State. ${ }^{380}$

In Burdick, the Court rejected the view expressed earher by Justice Field that the distinction between amnesty and pardon is "one rather of philological interest than of legal importance." ${ }^{391}$ In response to Field's opinion that amnesty and pardon are indistinguishable and that both extinguish guilt, the Court stated: "This is so as to their ultimate effect, but there are incidental differences of importance. They are of different character and have different purposes."302 Furthermore, a proper reading of Garland demonstrates the Court's recognition of guilt attached to a pardoned crime: "Literally, of course, an executive pardon cannot 'blot out of existence guilt' of one who committed a crine. At most it can wipe out the legal consequences which flow from an adjudication of guilt." 393

In support of this view, courts have generally held that the accept-

387. 5 Utah 131, 13 P. 237 (1887), rev'd on other grounds, 137 U.S. 496 (1890).

388. 5 Utah at 133,13 P. at 239 (citation omitted).

1 389. 236 U.S. 79 (1915).

390. Id. at 95 .

391. Knote v. United States, 95 U.S. 149, 153 (1877).

392. 236 U.S. at 94-95.

393. People ex rel. Prisament v. Brophy, 287 N.Y. 132, 136, 38 N.E.2d 468, 470

(1964) (applying Garland). 
ance of a pardon implies an admission of guilt, in exchange for the remission of penalties. ${ }^{304}$

Far from wiping out guilt, the acceptance of an executive pardon may imply a confession of guilt. Escape by confession of guilt implied in the acceptance of a pardon inay be rejected-preferring to be the victim of the law rather than its acknowledged transgressor-preferring death even to sucl certain infamy. ${ }^{395}$

Since an acceptance of a grant of pardon implies a confession of guilt, which cannot be blotted out of existence by executive whin, ${ }^{396}$ the pardon should logically follow, not precede, formal adjudication of the offenses. Luther Martin offered a motion in the Constitutional Convention to accomplish this result by making conviction a prerequisite to the reception of a pardon. Madison recorded that Martin moved to "'msert the words, 'after conviction,' after the words 'reprieves and pardons.' " However, Martin withdrew the motion when James Wilson noted that "pardon before conviction might be necessary, in order to obtain the testimony of accomplices."397 The framers, therefore, while not expressly requiring that conviction precede pardon, liad a narrow view as to those cases in which a pardon could legitimately be invoked prior to conviction. That narrow view clearly did not extend to the case where the pardon power is used to prevent a thorough investigation and a final determination of the guilt or innocence of public officials charged with illegal misconduct in office. Rather, the impeachment exception to the presidential pardon power was added as a circumscription to that power in order to avoid that very possibility. ${ }^{398}$

\section{The Nixon Pardon and Beyond}

President Ford's grant of pardon to former President Nixon may be criticized on several grounds. First, his exercise of the pardon power was inconsistent with its underlyimg purpose, that of serving justice. President Ford, in a news conference following the grant of pardon, admitted that the thirty-eight member House Judiciary Comimittee's final unanimous report in favor of impeachment and Nixon's

394. See, e.g., State v. Jacobsen, 348 Mo. 258, 260-61, 152 S.W.2d 1061, 1063 (1941); Jones v. State, 141 Tex. Crim. 70, 73-74, 147 S.W.2d 508, 510 (Crim. App. 1941); State v. Cullen, 14 Wash. 2d 105, 109, 127 P.2d 257, 259 (1942).

395. Burdick v. United States, 236 U.S. 76, 90-91 (1915).

396. See People ex rel. Prisanient v. Brophy, 287 N.Y. 132, 137-38, 38 N.E.2d 468,471 (1941), where the court stated that "[t]he Constitutiou, which confers upon the President the power to pardon, does not confer upon him power to wipe out guilt."

397. 5 J. ElLIOTT 480.

398. See text acconipanying note 378 supra. 
acceptance of the pardon constitute persuasive evidence of the former President's guilt. ${ }^{300}$ The pardon, following the discontinuation of the inpeachinent proceedings upon Nixon's resignation, implies that the President's conduct will not be measured by the same standard of justice that applies to all other persons. Confidence in our democratic system of justice demands that the law be applied to all persons equally and that public officials not be permitted to violate the laws with inpunity.

Second, the framers intended, by including the impeachment exception to presidential pardoning power, to avoid having the pardon used to obstruct a thorough investigation and ultimate congressional resolution of charges of official misconduct. A pardon granted prior to any final determination of the extent of presidential misdeeds in this case goes even further than would be permitted in Enghish law where the king could not invoke his pardon in the case of impeachment, both in a crimmal as well as a political proceeding, until after conviction and disgrace. The constitutional framers consciously separated the impeachment and the criminal processes in recognition of the facts that the two served different purposes and that removal from office alone was not an adequate sanction for public wrongdoing. Since Nixon was not inpeached or convicted (though both appeared inevitable in the absence of resignation), Ford's pardon suggests that future Presidents subjected to the impeachment process will escape criminal prosecution on the ground that their reinoval froin office has been punishment enough. This conception of punishment would seem to assune a property interest in political office, a notion hardly consistent with democratic government. To this extent, Nixon's pardon as precedent may effectively nullify the clause in the Constitution that an impeached official "shall nevertheless be liable and subject to Indictment, Trial, Judgment and Punishinent, according to Law." 400

In response to President Ford's questionable grant of pardon in this case, several steps could be taken. First, the constitutional validity of a pardon, incident to presidential misconduct which would have resulted in impeachment and conviction had not the accused resigned, could be challenged in the courts. Such an exercise of the pardon power is fundainentally inconsistent with the impeachment exception to that power. If Mr. Nixon were indicted, he would be compelled to raise the issue of the validity of the pardon as an affirmative defense to prosecution.

399. N.Y. Times, Sept. 17, 1974, at 22C, col. 1.

400. U.S. CoNST. art. I, § 3, cl. 7. 
Second, Congress could resume impeachment proceedings against Mr. Nixon for the purpose of a final determination of the extent of presidential wrongdoing. It is recognized, however, that whatever the theoretical correctness of such a procedure, ${ }^{401}$ Congress, for its own reasons, will not follow this course. In the alternative, Congress could provide the Special Prosecutor with a broadened mandate to include withm his final report to Congress all findings on the Watergate scandals, including the involveinent of Richard Nixon.

Third, the grant of pardon was accompanied by an agreement with Mr. Nixon concerning the handling of the papers and tapes accumulated while he was $\mathrm{m}$ the White House. These records are of critical importance with respect to pending criminal cases and a final determination of the facts of executive misconduct. Although the agreement included a provision whereby Nixon would voluntarily produce items in response to court subpoenas, the documents remani subject to any claims of privilege he may assert, and what is not made clear in the agreennent is whether these documents, which were previously categorized as public and therefore not subject to the privilege against self-incrimination asserted by the custodian of the materials, are now to be considered personal and therefore subject to Mr. Nixon's privilege against self-incrimination. The pardon does not moot this issue. Although a federal pardon precludes the use of the privilege against selfincrimination for federal crimes, the privilege nevertheless can be invoked where state charges may be possible. ${ }^{402}$ Therefore, it would appear that Mr. Nixon may be compelled to testify and to produce White House papers and tapes only if he is granted witness immunity under his own anticrime statute of $1970 .^{403}$ Although the agreenent concerning the tapes and papers grants custody of the White House documents to Mr. Nixon, the public nature of the materials and the express provisions that they be made available for criminal proceedings may be sufficient to overrule any claim of privilege later asserted by Mr. Nixon. ${ }^{404}$ Congress could and should avoid the issue, however, by requiring that ownership of all presidential papers be retained by the government for purposes of preservation and inspection.

401. See notes 360-65 supra and accompanying text.

402. See Murphy v. Waterfront Comm'n 378 U.S. 52 (1964) (holding that one jurisdiction may not, absent an immunity provision, compel a witness to give testimony which might incriminate him under the laws of another jurisdiction).

403. See Omnibus Criminal Control Act, 18 U.S.C. $\$ 6002$ (1970).

404. A public official's privilege against self-incrimination does not extend to public documents or papers in the official's possession smce it wonld be an imtolerable burden for the government to be unable to discover what its own doings are. See $7 \mathrm{~J}$. WIGMORE, supra note $309, \S 2259$ (c) (1). 
The particular interworkings of the impeachment process, presidential resignation, the twenty-fifth amendment, and the pardon power demonstrate once again the limits of institutional constraints upon human discretion. Our government is, always has been, and will continue to be conducted by both laws and inen. The ambiguities of the presidential pardon power, together with the twenty-fifth amendment, have permitted a President appointed by his predecessor to the VicePresidency to pardon his benefactor when the latter faced possible criminal prosecution for the offenses which drove him from office. The result has been to undermine the concept of equal justice under law, to delay, if not foreclose, a final determination of Mr. Nixon's role in the Watergate scandals, and to erode the confidence of the electorate in the Ford administration.

And yet proposed institutional reforms to prohibit such a confluence of factors in the future are also flawed. Repeal of the twentyfifth amendment could return us to a line of succession to the presidency which has already proved itself to be unattractive. Banning presidential pardons in every case until conviction and sentencing, as originally proposed by Luther Martin and now suggested by Congressman John Dent, ${ }^{405}$ would not only prevent the abuse of discretion present in the Nixon pardon but also would inake impossible the compassionate use of such power when the health of the recipient, or the administration of justice, might mandate such action. It is suggested that in this instance, the American penchant for an institutional response to every perceived human failing be restramed for the present. Let the decision to pardon the former President be weighed by the electorate, after passage of time has improved our perspective as to its merit, as we would do with any other political judgment of substantial magnitude.

\section{CONCLUSION}

Any government is free to the people under it (whatever be the frame) when the laws rule, and the people are a party to these laws, and more than this is tyranny, oligarchy, or confusion. But, lastly, when all is said, there is hardly one frame of government in the world so ill designed by its first founders, that, in good hands, would not do well enough . . . . Governments, like clocks, go froin the motion men give thein; and as governments are made and moved by men, so by them are they ruined too. Wherefore governments rather depend upon men,

405. H.R.J. Res. 1125, 93d Cong., 2d Sess. (1974); cf. ABA Report on Pardons, 43 U.S.L.W. 2143 (Oct. 18, 1974). 
than men upon governments. Let men be good, and the government cannot be bad; if it be ill, they will cure it. But if men be bad, let the government be never so good. They will endeavor to warp and spoil it to their turn.

William Penn ${ }^{408}$

The impeachment process cannot properly be evaluated apart from its constitutional matrix. Of course, executive wrongdoing could be remedied more simply by legislative action within a system in which the legislative branch is supreme. ${ }^{407}$ This recognition, however, is hittle more than tautology. In a government in which the executive is a subordinate part of and is responsible to the legislature, executive nnaladministration is the direct responsibility of a legislative institution

406. Preface to W. Penn, Frame of Government for PENnSYlVANIa (1682).

407. Members of the Constitutional Convention considered and rejected the notion of executive tenure at the pleasure of the legislature. Madison, in objecting to "maladministration" as a term to be joined with treason and bribery as constituting grounds for impeachment, noted that "so vague a term will be equivalent to a tenure during pleasure of the Senate." "High Crimes and Misdemeanors" was then selected from English law presumably because it possessed a sufficiently definable content from English usage to avoid the spectre of executive tenure at the sufferance of Congress. 2 RECORDS 550. The system which they chose called for an executive electoral mandate independent of Congress and for a set term of years, to be terminated earlier only upon death, resignation, or inability to discharge the duties of the office, U.S. CONST. art. II, $\S 1$, or upon conviction for the commission of treason, bribery, or other high crimes and misdemeanors, id. art. $I, \S 4$.

Rejection of the parliamentary model in no way reflects a qualitative judgment between the two systems; rather, it is a simple acknowledgement that the substitution of a "foreign tradition for an indigenous one" will likely not take root. Merryman in his description of the works of Beccaria and other reformers of criminal procedure in eighteenth century France, noted the atteinpts to transplant English criminal procedure (the jury, oral public procedure in place of secret written procedure, right of counsel for the accused, restriction of the judge's inquisitorial powers) into the French civil law tradition:

In the fervor of the French Revolution an atteinpt was made to abolish the criminal procedure of the old regime and substitute an entirely new one based on the English model. The failure of the effort to substitute a foreign tradition for an indigenous one soon became apparent, and a counterrevolution in criminal procedure took place in France. The result is a mixed systein, composed in part of elements from prerevolutionary times and in part of reforms imposed after the Revolution. J. MERrYMan, THE CIVIL LAW Tradition 137 (1969).

The failure of a transplanted system seems especially likely when it is designed to replace the very essence of the infrastructure of the American state, namely, the concept of the separation of powers. While our conclusion does not constitute any criticism of the parliamentary concept, it should be noted that the performance of our own Congress gives little reason to be any more sanguine about the prospects for honest and efficient government under legislative direction than under the present mix. However, in view of the historical precedents, it would seem unwise for Congress to adopt any of the current Watergate-inspired proposals to change our governmental structure in favor of a parhamentary mode. See note 2 supra and accompanying text. 
presumably equipped to accept such a duty. The American system, however, has been built upon the concept of separate, coordinate branehes of government with the pohtical branches each having independent and direct electoral bases. Impeachment must ultimately be judged within this context.

We, therefore, should seek to analyze, reform, and utilize the impeachment tool within the bounds set by the basic structure of our system. Circumscribed within that environment, several observations and recommendations are offered in conclusion. First, impeachment must be seen as only one of several weapons in our system to combat ministerial abuse. Impeachment cannot be judged as if it alone must be able to deter executive abuse and then, if found wanting, discarded. For dealing with most problems, there are other effective political and social mechanisms, which include, to name the more obvious: the electoral judgment, judicial review of executive administrative deeisions, congressional control over legislation and the purse, a free press ideally in constant tension with the objects of its reporting, a party structure sufficiently strong to aet as a constraint upon arbitrary presidential action, a White House staff with "semiors committed to republican government and the rule of law and jumors sufficiently beyond identity crises to avoid seduction," ${ }^{408}$ a Cabinet with at least some members possessing a political, bureaucratic, or professional base imdependent of their connection to the President, and a professional bureaucracy with a tradition of adherence to the law strong enough to withstand subversion.

Second, the process of impeachinent must be viewed in its entirety, encompassing not only its constitutional, textual content but also the other actions that customarily accompany it. Resignation has becone the usual means of removal following the initiation of impeachment proceedings; it is more often accomplished than conviction and cannot be considered as extra-legal or as evidence of the failure of the impeachment system. Nor are criminal prosecutions subsequent to an impeachment to be viewed as an unrelated or precluded portion of the impeachment process. As the criminal sanctions which could be applied under the English model were excluded from the process of American impeachment, the possibility of subsequent criminal prosecution and punishment was carefully excepted from the prohibitions against double jeopardy. Furthermore, censure, though used only once against a President, ${ }^{409}$ has been employed often against judges

408. Firmage, Law and the Indochina War: A Retrospective View, supra note 3, at 20.

409. Censure has been invoked against a President, Andrew Jackson, by the Senate 
and members of Congress, ${ }^{410}$ and could well play an important role in restricting presidential conduct. ${ }^{411}$ Refusal to use these mechanisms, available along with or as part of the impeachment process, when justice would warrant their use, represents not a weakness of constitutional structure but rather a failure of political will.

When impeachment is evaluated as only one of many institutions of constraint upon ministerial abuse and when it is seen in its larger context to include not only its textual definition of the offense, trial, conviction, and removal but also other integrally related textual matters such as resignation ${ }^{412}$ and further criminal prosecution and punishinent, ${ }^{413}$ together with censure as an alternative or supplementary sanction, the entire process seems a worthy instrument of republican government. Its performance in the Nixon case has been no exception to this judgment. Even so, our experience with the impeachment process which led to the resignation of former-President Nixon has re-

for his removal of governmental deposits from the Bank of the United States in an effort to cause its failure. Jackson, who had the support of the House, challenged the Senate's authority to censure: "If Congress really meant what the Senate said, ... let the House impeach him and the Senate try him." A. SCHLEsInger, THE IMPERIAL PRESDENCY 411-12 (1973).

410. "Fifteen House Members have been censured. . . . The Senate has resorted to censure on seven occasions." J. KIRBY, Congress aND THE PUBLIC Trust 210 (1970). In addition, "[o]f the fifty-five federal judges subjected to House Judiciary Committee scrutiny, eight were impeached of whom four were convicted, and eight were censured." BoRKIN, supra note 345, at 204.

411. Arthur Schlesinger examined Jackson's response and concurred as a matter of constitutional principle:

Jackson was plainly right. If a President committed high crimes and misdemeanors, censure was not enough. The slap-on-the-wrist approach to presidential delinquency made little sense, constitutional or otherwise. . . . This did not mean, of course, that a fainthearted Congress might not censure a lawless President and pretend to have done its duty, but unless the terms of the resolution made it clear why the President was inerely censurable and not impeachable, the action would be a cop-out and a betrayal of Congress' constitutioual responsibility. A. SCHLESINGER, supra note 409, at 422.

It goes without saymg that the Congress is well advised on any account to clearly delmeate the grounds upon which its decision is made whenever a President is censured rather than impeached. This, however, in no way implies that the use of censure is itself an admission of congressional weakness or faintheartedness. If the resolution of censure is drafted articulately, it may function as a "trial balloon" and communicate important political sentiments to the President and the electorate alike, as well as serve significantly as a notice to the President that he is on a collision course with Congress. Even where a President is impeached, Congress could use a vote of censure to warn future Presidents what conduct it found objectionable, even if not conclusively impeachable, offenses. For example, the defeated article of impeachment covering Nixon's alleged tax irregularities may well have been converted into an effective vote of censure.

412. U.S. CoNST, art. 2, § 1, cl. 6.

413. $I d$. art. $1, \S 3$, cl. 7 . 
vealed some areas of needed reform. First, the fact-finding powers of Congress in an impeachment proceeding must be affirmed without ambiguity. The impeachment process is one of those rare instances in which the separation of powers is held in abeyance with one particular branch in the ascendancy for a time, in the words of Representative Boudinot, impeachment represents "an exception to [the] principle"114 of separation of powers, with Congress possessed of the authority to acquire that information necessary and proper to accomplish its constitutionally mandated task. The single most important fact which retarded the impeachment imvestigation of President Nixon was his refusal to comply with congressional subpoenas on the basis of executive privilege. ${ }^{415}$ It is suggested that the relative weight to be accorded a congressional demand for persons and papers in an impeachment proceeding investigating the alleged commission of high crimes and misdeneanors by the President, with its constitutional foundation, is incomparably greater than that which must now be accorded a prosecutor within the executive branch investigating the alleged commission of a conspiracy to obstruct justice. Congress by joint resolution should express its opimion that failure to comply with its subpoenas, duly authorized in an impeaclınent proceeding, would constitute the commission of an impeachable offense. Legitimation of an executive refusal to do so would effectively cripple the impeachment process. The law announced in the third article of impeachment, shorn of its particular factual accusations against President Nixon, should be ratified by Congress. Having asserted jurisdiction to issue subpoenas, Congress could justifiably rely on the assumption that the Supreme Court would refuse to review the exercise of that subpoena power whenever it is conducted pursuant to a proper assertion of the impeachment power. Consequently, Congress by its actions must firmly establish this precedent. Without adequate fact-finding powers incident to an impeachment proceeding, Congress, already weakened seriously as a coordinate balance to the awesome executive branch, would find the powerful if cumbersome weapon of impeachment effectively spiked. Ultimately, it can only be Congress, a coordinate political branch, which effectively checks and balances its pohitical colleague and natural adversary.

Second, there is need to revise the procedural rules of impeaclment at a time when no actual case is impending in Congress. Antiquated evidentiary rules, which do not reflect the political nature of

414. 1 ANnals of Cong., supra note 9.

415. The Supreme Court's ruling in United States v. Nixon, 94 S. Ct. 3090 (1974), effectively destroyed the assertion of absolute executive privilege. 
the impeachment trial and which are vestiges either of judicial rules relevant only to trial by jury or of Enghish impeachments which carried criminal sanctions, should be reformulated. ${ }^{416}$ Such reform should include, among other things, a provision stated in the form of a policy directing open liearings during all but the earliest stages of the impeachment of the high officials of the state, with a special provision made for coverage by the mass media, particularly television. ${ }^{417}$ To fulfill its object of governmental protection, the impeachment process should be accomplished with popular ratification of its direction, progress, and conclusion. Neither impeachment and conviction nor exoneration can with good effect take place until an electoral mandate is either ended or reaffirmed. Perceived legitimacy ${ }^{418}$ of the incumbent admimistration or its successor cannot exist without popular ratification of the result of the impeachment inquiry; that in turn can only be accomplished through the electromic media.

Third, the nature of the House and Senate votes on impeachment should be altered to allow a more accurate, less ambiguous ineans of common law development of the definition of an impeachable offense. ${ }^{419}$ These votes should distinguish findings of fact and law. An impeachment vote should first clearly reflect whether the congressmen believed the respondent to be guilty of the offense charged and, second, whether its commission was considered to constitute impeachable conduct.

Beyond improving the impeachment process, modern Congresses should be more aware of the use of censure as a means, short of impeachment, of expressing their disapproval of presidential conduct. There is no reason why Congress may not in certaim situations vote a resolution of censure agamst a President. The Congress historically has resorted to censure as a sanction more often than it has voted to impeach and convict: "Fifteen House Members have been censured .... The Senate has resorted to censure on seven occasions. ${ }^{\$ 20}$ In addition, "[of] the fifty-five federal judges subjected to House Judiciary Committee scrutiny, eight were impeached of whom four were convicted, and eight were censured." ${ }^{21}$

Furthermore, where a President is impeached and his pattern of conduct, $\mathrm{m}$ addition to impeachable offenses, includes constitutionally

416. See section IV, E, accompanying notes 225-31 supra.

417. See section III, G, accompanying notes $101-03$ supra.

418. See note 3 supra.

419. See notes 234-36 supra and accompanying text.

420. J. KIRBY, supra note 410.

421. BorkIN, supra note 345, at 204. 
objectionable acts not necessarily rising to the level of impeachability, the Congress should vote censure for those acts as well as impeachment for the commission of high crimes and misdemeanors. In such a case, the sanction would be aimed not simply against the accused but prospectively in an effort to outline the parameters of what Congress considers constitutional conduct.

\section{EPILOGUE}

Oliver Goldsmith noted some time ago: "How small, of all that human liearts endure, that part which laws or kings can cause or cure." 422 However, recent events have denonstrated how disproportionate is the liarm to the political fabric which a king (or President) can cause when compared to the ability of the law to contain such harm. Our legal institutions, were able to contain this harm only with the best of luck. An unlikely concatenation of events-the inept burglary of the Democratic Party Headquarters, the lost notebook revealing White House involvement, the chance disclosure of the presidential tape recordings-saved our system this time. Institutions are at best frail defenses against the propensities of men. Ours worked better than most but inust still be improved. The combination of good men and good laws together represent the ultimate safeguard for republican government.

422. The Complete Poetical Works of Oltver Goldsmith 19 (Oxford ed. 1911) ("The Traveler," verse 3). 


\section{APPENDICES}

\section{APPENDIX A \\ JUdiciary COMMITTEE'S IMPEACHMENT InNQUIRY PROCEDURes IN THE NIXON IMPEACHMENT}

The House Judiciary Committee on May 2, 1974, adopted the following procedural rules for the Nixon inquiry:

A. The committee shall receive from committee counsel at a hearing an initial presentation consisting of (i) a written stateinent detailing, in paragraph form, information believed by the staff to be pertinent to the inquiry, (ii) a general description of the scope and manner of the presentation of evidence, and (iii) a detailed presentation of the evidentiary material, other than the testimony of witnesses.

1. Each meinber of the committee shall receive a copy of (i) the statement of information, (ii) the related documents and other evidentiary inaterial, and (iii) an index of all testimony, papers, and things that have been obtained by the committee, whether or not relied upon in the stateinent of information.

2. Each paragraph of the statement of information shall be annotated to related evidentiary material (e.g., documents, recordings and transcripts thereof, transcripts of grand jury or congressional testimony, or affidavits). Where applicable, the annotations will identify witnesses believed by the staff to be sources of additional information important to the committee's understanding of the subject matter of the paragraph in question.

3. On the commencement of the presentation, each member of the committee and full committee staff, majority and minority, as designated by the chairman and the ranking minority meinber, shall be given access to and the opportunity to examine all testimony, papers and things that have been obtaimed by the inquiry staff, whether or not relied upon in the statement of information.

4. The President's counsel shall be furnished a copy of the statement of information and related documents and other evidentiary material at the time that those materials are furnished to the members and the President and his counsel shall be invited to attend and observe the presentation.

B. Following that presentation the coinmittee shall determine whether it desires additional evidence, after opportunity for the following has been provided:

1. Any comunittee member may bring additional evidence to the cominittee's attention.

2. The President's counsel shall be invited to respond to the preseutation, orally or in writing as shall be determined by the committee.

3. Should the President's counsel wish the committee to receive additional testimony or other evidence, he shall be imvited to submit written requests and precise summaries of what he would propose to show, and in the case of a witness precisely and in detail what it is expected the testimony of the witness would be, if called. On the basis of such requests and summaries and of the record then before it, the committce shall determine whether the suggested evidence is necessary or desirable to a full and fair record in the inquiry, and, if so, whether the summaries shall be accepted as part of the record or additional testimony or evidence in some other form shall be received.

C. If and when witnesses are to be called, the following additional procedures shall be applicable to hearings held for that purpose.

1. The President and his counsel shall be invited to attend all hearings, including any held in executive session. 
2. Objections relating to the examination of witnesses or to the admissibility of testimony and evidence may be raised only by a witness or his counsel, a member of the committee, committee counsel or the President's counsel and shall be ruled upon by the chairman or presiding member. Such rulings shall be final, unless overruled by a vote of a majority of the members present. In the case of a tie vote, the ruling of the chair shall prevail.

3. Committee counsel shall commence the questioning of each witness and may also be permitted by the chairman or presiding member to question a witness at any point during the appearance of the witness.

4. The President's counsel may question any witness called before the committee, subject to instructions from the chairman or presiding member respecting the time, scope and duration of the examination.

D. The committee shall determine, pursuant to the rules of the House, whether and to what extent the evidence to be presented shall be received in executive session.

E. Any portion of the hearings open to the public may be covered by television broadcast, radio broadcast, still photography, or by any of such methods of coverage in accord with the rules of the House and the rules of procedure of the committee as amended on November 13, 1973.

F. The chairman shall make public announcement of the date, time, place and subject matter of any committee hearing as soon as practicable and in no event less than twenty-four hours before the commencement of the hearing.

G. The chairman is authorized to promulgate additional procedures as he deems necessary for the fair and efficient conduct of committee hearings held pursuant to $\mathrm{H}$ Res. 803, provided that the additional procedures are not inconsistent with these procedures, the rules of the committee, and the rules of the House. Such procedures shall govern the conduct of the hearings, unless overruled by a vote of a majority of the members present.

H. For purposes of hearings held pursuant to these rules, a quorum shall consist of ten members of the committee.

\section{APPENDIX B}

\section{Senate Impeachment Procedure RULes}

I. Whensoever the Senate shall receive notice from the House of Representatives that managers are appointed on thcir part to conduct an mipeachment against any person and are directed to carry articles of impeachment to the Senate, the Secretary of the Senate shall immediately inform the House of Representatives that the Senate is ready to receive the managers for the purpose of exhibiting such articles of impeachment, agreeably to such notice.

II. When the managers of an mipeachment shall be introduced at the bar of the Senate and shall signify that they are ready to exhibit articles of mipeachment against any person, the Presiding Officer of the Senate shall direct the Sergeant at Arms to make proclamation, who shall, after making proclamation, repeat the following words, viz: "All persons are commanded to keep silence, on pain of imprisonment, while the House of Representatives is exhibiting to the Senate of the United States articles of impeachment against —_ after which the articles shall be exhibited, and then the Presiding Officer of the Senate shall inform the managers that the Senate will take proper order on the subject of the impeachment, of which due notice shall be given to the House of Representatives.

mI. Upon such articles being presented to the Senate, the Senate shall, at 1 o'clock afternoon of the day (Sunday excepted) following such preseutation, or sooner if ordered by the Senate, proceed to the consideration of such articles, and shall con- 
tinue in session from day to day (Sundays excepted) after the trial shall commence (unless otherwise ordered by the Senate) until final judgment shall be rendered, and so much longer as may, in its judgment, be needful. Before proceeding to the consideration of the articles of impeachment, the Presiding Officer shall administer the oath hereinafter provided to the members of the Senate then present and to the other members of the Senate as they shall appear, whose duty it shall be to take the same.

IV. When the President of the United States or the Vice President of the Umited States, upon whom the powers and duties of the office of President shall have devolved, shall be impeached, the Chief Justice of the Supreme Court of the United States shall preside; and in a case requiring the said Chief Justice to preside notice shall be given to him by the Presiding Officer of the Senate of the time and place fixed for the consideration of the articles of impeachment as aforesaid, with a request to attend; and the said Chief Justice shall preside over the Senate during the consideration of said articles aud upon the trial of the person impeached therein.

V. The Presiding Officer shall have power to make and issue, by himself or by the Secretary of the Senate, all orders, mandates, writs, and precepts authorized by these rules or by the Senate, and to nake and enforce such other regulations and orders in the premises as the Seuate may authorize or provide.

VI. The Senate shall have power to compel the attendance of witnesses, to enforce obedience to its orders, mandates, writs, precepts, and judgments, to preserve order, and to punish in a summary way contempts of and disobedience to, its authority, orders, niandates, writs, precepts, or judgments, and to make all lawful orders, rules, and regulations which it may deem essential or conducive to the ends of justice. And the Sergeant at Arms, under the direction of the Senate, may employ such aid and assistance as may be necessary to enforce, execute, and carry into effect the lawful orders, mandates, writs, and precepts of the Senate.

VII. The Presiding Officer of the Senate shall direct all necessary preparations in the Senate Chamber, and the Presiding Officer on the trial shall direct all the forms of proceedings while the Senate is sitting for the purpose of trying an impeachment, and all forms during the trial not otherwise specially provided for. And the Presiding Officer on the trial may rule all questions of evidence and incidental questions, which ruling shall stand as the judgment of the Senate, unless some nember of the Senate shall ask that a formal vote be taken thereon, in which case it shall be submitted to the Senate for decision; or he may at his option, in the first instance, subınit any such question to a vote of the members of the Senate. Upon all such questions the vote shall be without a division, unless the yeas and nays be demanded by one-fifth of the members present, when the same shall be taken.

VIII. Upon the presentation of articles of impeachment and the organization of the Senate as hereinbefore provided, a writ of summons shall issue to the accused, reciting said articles, and notifying him to appear before the Senate upon a day and at a place to be fixed by the Senate and named in such writ, and file his answer to said articles of impeachment, and to stand to and abide the orders and judgments of the Senate thereon; which writ shall be served by such officer or person as shall be named in the precept thereof, such number of days prior to the day fixed for such appearance as shall be named in such precept, either by the delivery of an attested copy thereof to the person accused, or if that cannot conveniently be done, by leaving such copy at the last known place of abode of such person, or at his usual place of business in some conspicuous place therein; or if such service shall be, in the judgment of the Senate, impracticable, notice to the accused to appear shall be given in such other inanner, by publication or otherwise, as shall be deemed just; and if the writ aforesaid shall fail to service in the manner aforesaid, the proceedings shall not thereby abate, but further service may be made iu such nanner as the Senate shall direct. If the accused, after service, shall fail to appear, either in person or by attorney, on the day so fixed there- 
for as aforesaid, or, appearing, shall fail to file his answer to such articles of impeachment, the trial shall proceed, nevertheless, as upon a plea of not guilty. If a plea of guilty shall be entered, judgment may be entered thereon without further proceedings.

IX. At 12:30 o'clock afternoon of the day appointed for the return of the summons against the person impeached, the legislative and executive business of the Senate shall be suspended, and the Secretary of the Senate shall adininister an oath to the returning officer in the form following, viz: "I, _ _ _ _ do solemnly swear that the return made by me upon the process issued on the - day of $\longrightarrow$, by the Senate of the Urnted States, against _-_ truly made, and that I have performed such service as therein described: So help me God." Which oath shall be entered at large on the records.

$X$. The person impeached shall then be called to appear and answer the articles of impeachment against him. If he appear, or any person for hin, the appearance shall be recorded, stating particularly if by himself, or by agent or attorney, naming the person appearing and the capacity in which he appears. If he do not appear, either personally or by agent or attorney, the same shall be recorded.

XI. That in the trial of any impeachment the Presiding Officer of the Senate, upon the order of the Senate, shall appoint a committee of twelve Senators to receive evidence and take testimony at such times and places as the committee may determine, and for such purpose the committee so appointed and the chairman thereof, to be elected by the committee, shall (unless otherwise ordered by the Senate) exercise all the powers and functions conferred upon the Senate and the Presiding Officer of the Senate, respectively, under the rules of procedure and practice in the Senate when sitting on impeachment trials.

Unless otherwise ordered by the Senate, the rules of procedure and practice in the Senate when sitting on impeachment trials shall govern the procedure and practice of the committee so appointed. The committee so appointed shall report to the Senate in writing a certified copy of the transcript of the proceedings and testimony had and given before such committee, and such report shall be received by the Senate and the evidence so received and the testimony so taken shall be considered to all intents and purposes, subject to the right of the Senate to determine competency, relevancy, and materiality as having been received and taken before the Senate, but nothing herein shall prevent the Senate from sending for any witness and hearing his testimony in open Senate, or by order of the Senate having the entire trial in open Senate.

XII. At 12:30 o'clock afternoon of the day appointed for the trial of an impeachment, the legislative and executive business of the Senate shall be suspended, and the Secretary shall give notice to the House of Representatives that the Senate is ready to proceed upon the impeachment of _—_ in the Senate Chamber, which chamber is prepared with accommodations for the reception of the House of Representatives.

XIII. The hour of the day at which the Senate shall sit upon the trial of an impeachment shall be (unless otherwise ordered) 12 o'clock $\mathrm{m}$.; and when the hour for such thing shall arrive, the Presiding Officer of the Senate shall so announce; and thereupon the Presiding Officer upon such trial shall cause proclamation to be made, and the business of the trial shall proceed. The adjournment of the Senate sitting in said trial shall not operate as an adjournment of the Senate; but on such adjournment the Senate shall resume the consideration of its legislative and executive business.

XIV. The Secretary of the Senate shall record the proceedings in cases of inpeachment as in the case of legislative proceedings, and the same shall be reported in the same manner as the legislative proceedings of the Senate.

XV. Counsel for the parties shąll be admitted to appear and be hẹard upon an jmpeachment, 
XVI. All motions made by the parties or their counsel shall be addressed to the Presiding Officer, and if he, or any Senator, shall require it, they shall be committed to writing, and read at the Secretary's table.

XVII. Witnesses shall be examined by one person on behalf of the party producing them, and then cross-examined by one person on the other side.

XVIII. If a Senator is called as a witness, he shall be sworn, and give his testimony standing in his place.

$\mathrm{XIX}$. If a Senator wishes a question to be put to a witness, or to offer a motion or order (except a motion to adjourn), it shall be reduced to writing, and put by the Presiding Officer.

XX. At all times while the Senate is sitting upon the trial of an impeachment the doors of the Senate shall be kept open, unless the Senate shall direct the doors to be closed while deliberating upon its decisions.

XXI. All preliminary or interlocutory questions, and all motions, shall be argued for not exceeding one hour on each side, unless the Senate shall, by order, extend the time.

XXII. The case, on each side, shall be opened by one person. The final argument on the merits may be made by two persons on each side (unless otherwise ordered by the Senate upon application for that purpose), and the argument shall be opened and closed on the part of the House of Representatives.

XXIII. On the final question whether the impeachment is sustained, the yeas and nays shall be taken on each article of impeachment separately; and if the impeachment shall not, upon any of the articles presented, be sustained by the votes of two-thirds of the members present, a judgment of acquittal shall be entered; but if the person accused in such articles of impeachment shall be convicted upon any of said articles by the votes of two-thirds of the members present, the Senate shall proceed to pronounce judgment, and a certified copy of such judgment shall be deposited in the office of the Secretary of State.

XXIV. All the orders and decisions shall be made and had by yeas and nays, which shall be entered on the record, and without debate, subject, however, to the operation of Rule VII, except when the doors shall be closed for deliberation, and in that case no meinber shall speak more than once on one question, and for not more than ten minutes on an interlocutory question, and for not more than fifteen minutes on the final question, unless by consent of the Senate, to be had without debate; but a motion to adjourn may be decided without the yeas and nays, unless they be demanded by one-fifth of the meinbers present. The fifteen minutes herein allowed shall be for the whole deliberation on the final question, and not to the final question on each article of impeachment.

XXV. Witnesses shall be sworn in the following form, viz: "You, , do swear (or affirm, as the case may be) that the evidence you shall give in the case now pending between the United States and shall be the truth, the whole truth, and nothing but the truth: So help you God." Which oath shall be administered by the Secretary, or any other duly authorized person.

\section{APPENDIX C}

\section{ARTICLES OF IMPEACHMENT}

The House Judiciary Committee, subsequent to its investigation of the Nixon presidency, voted the following articles of impeachment:

\section{ARTICLE I}

In his conduct of the office of President of the United States, Richard M. Nixon, 
in violation of his constitutional oath faithfully to execute the office of President of the United States and, to the best of his ability, preserve, protect and defend the Constitution of the United States, and in violation of his constitutional duty to take care that the laws be faithfully executed, has prevented, obstructed, and impeded the administration of justice, in that:

On June 17, 1972, and prior thereto, agents of the Committee for the Re-election . of the President:

Committed unlawful entry of the headquarters of the Democratic National Committee in Washington, District of Columbia, for the purpose of securing political intelligence. Subsequent thereto, Richard M. Nixon, using the powers of his high office, engaged personally and through his subordinates and agents in a course of conduct or plan designed to delay, impede, and obstruct the investigation of such unlawful entry; to cover up, conceal and protect those responsible; and to conceal the existence and scope of other unlawful covert activities.

The means used to implement this course of conduct or plan have included one or more of the following:

[1]

Making or causing to be made false or misleading statements to lawfully authorized investigative officers and employes of the United States.

[2]

Withholding relevant and material evidence or information from lawfully authorized investigative officers and employes of the United States.

Approving, condoning, acquiescing in, and counseling witnesses with respect to the giving of false or misleading statements to lawfully authorized investigative officers and employes of the United States and false or misleading testinony in duly instituted judicial and Congressional proceedings.

[4]

Interfering or endeavoring to interfere with the conduct of investigations by the Department of Justice of the United States, the Federal Bureau of Investigation, the office of Watergate Special Prosecution Force, and Congressional committees.

[5]

Approving, condoning and acquiescing in the surreptitious payment of substantial sums of money for the purpose of obtaining the silence or influencing the testimony of witnesses, potential witnesses or individuals who participated in such illegal entry and other illegal activities.

[6]

Endeavoring to misuse the Central Intelligence Agency, an agency of the United States.

[7]

Disseminating information received from officers of the Department of Justice of the United States to subjects of investigations conducted by lawfully authorized investigative officers and employes of the United States, for the purpose of aiding and assisting such subjects in their attempts to avoid criminal liability.

[8]

Making false or misleading public statements for the purpose of deceiving the people of the United States into believing that a thorough and complete investigation had been conducted with respect to allegations of misconduct on the part of personnel of the executive branch of the United States and personnel of the Committee for the Reelection of the President, and that there was uo involvement of such personnel in such misconduct; or

Endeavoring to cause prospective defendants, and individuals duly tried and con- 
victed, to expect favored treatment and consideration in return for their silence or false testimony, or rewarding individuals for their silence or false testimony.

In all of this, Richard $M$. Nixon has acted in a inanner contrary to his trust as President and subversive of constitutional governinent, to the great prejudice of the cause of law and justice and to the inanifest injury of the people of the United States.

Wherefore Richard M. Nixon, by such conduct, warrants impeachment and trial, and removal from office.

\section{ARTICLE II}

Using the powers of the office of President of the United States, Richard M. Nixon, in violation of his constitutional oath faithfully to execute the office of President of the United States, and to the best of his ability preserve, protect and defend the Constitution of the United States, and in disregard of his constitutional duty to take care that the laws be faithfully executed, has repeatedly engaged in conduct violating the constitutional rights of citizens, impairing the dne and proper administration of justice in the conduct of lawful inquiries, of contravening the law of governing agencies of the executive branch and the purposes of these agencies.

This conduct has included one or nore of the following:

\section{[1]}

He has, acting personally and through his subordinates and agents, endeavored to obtain from the Internal Revenue Service in violation of the constitutional rights of citizens, confidential information contained in incoine tax returns for purposes not authorized by law; and to cause, in violation of the constitutional rights of citizens, income tax audits or other income tax investigations to be initiated or conducted in a discriminatory nuanner.

He misused the Federal Bureau of Investigation, the Secret Service and other executive personnel in violation or disregard of the constitutional rights of citizens by directing or authorizing such agencies or personnel to conduct or continue electronic surveillance or other investigations for purposes unrelated to national security, the enforcennent of laws or any other lawful function of his office.

He did direct, authorize or permit the use of information obtained thereby for purposes unrelated to national security, the enforcement of laws or any other lawful function of his office. And he did direct the concealment of certain records made by the Federal Bureau of Investigation of electronic surveillance.

[3]

He has, acting personally and through his subordinates and agents, in violation or disregard of the constitutional rights of citizens, authorized and permitted to be nuaintained a secret investigative unit within the office of the President, financed in part with money derived from campaign contributions, which unlawfully utilized the resources of the Central Intelligence Agency, engaged in covert and unlawful activities, and attempted to prejudice the constitutional right of an accused to a fair trial.

He has failed to take care that the laws were faithfully executed by failing to act when he knew or had reason to know that his close subordinates endeavored to inpede and frustrate lawful inquiries by duly constituted executive, judicial and legislative entities concerning the unlawful entry into the headquarters of the Deinocratic National Committee and the cover-up thereof and concerning other unlawful activities including those relating to the confirmation of Richard Kleindienst as Attorney General of the United States, the electronic surveillance of private citizens, the break-in into the offices of Dr. Lewis Fielding and the campaign financing practices of the Committee to Re-elect the President. 
[5]

In disregard of the rule of law he knowingly misused the executive power by interfering with ageucies of the executive branch including the Federal Bureau of Investigation, the Crininal Division and the office of Watergate special prosecution force of the Departinent of Justice, and the Central Intelligence Agency, in violation of his duty to take care that the laws be faithfully executed.

In all of this Richard $M$. Nixon has acted in a manner contrary to his trust as President and subversive of constitutional government to the great prejudice of the cause of law and justice and to the manifest injury of the people of the United States.

Wherefore, Richard M. Nixon by such conduct warrants impeachinent and trial and removal from office.

\section{ARTICLE III}

In his conduct of the office of President of the United States, Richard M. Nixon, contrary to his oath faithfully to execute the office of President of the United States and to the best of his ability to preserve, protect and defend the Constitution of the United States, and in violation of his constitutional duty to take care that the laws be faithfully excented, has failed without lawful cause or excuse to produce papers and things, as directed by duly authorized subpoenas issued by the Committee ou the Judiciary of the House of Representatives on April 11, 1974, May 15, 1974, May 30, 1974, and June 24, 1974, and willfully disobeyed such subpoenas.

The subpoenaed papers and things were deemed necessary by the committee in order to resolve by direct evidence fundamental factual questions relating to Presidential direction, knowledge or approval of actions demonstrated by other evidence to be substantial grounds for impeachment of the President.

In refusing to produce these papers and things Richard M. Nixon, substituting his judgment as to what materials were necessary for the inquiry, interposed the powers of the Presidency against the lawful subpoenas of the House of Represeutatives, thereby assuming for himself fnnctions and judgments necessary to the exercise of the sole power of impeachinent vested by the Constitution in the House of Representatives.

In all this, Riclard $M$. Nixon lias acted in a manner contrary to his trust as President and subversive of constitutional government, to the great prejudice of the cause of law and justice, and to the manifest injnry of the people of the United States.

Wherefore, Ricliard M. Nixon, by such conduct warrants impeachment and trial and removal fronı office. 